Illinois State University

ISU ReD: Research and eData

Theses and Dissertations

$2-5-2020$

\title{
An Analysis of Campus Services for International Students at Institutions in the Midwest
}

Sylvia Miriyam Findlay

Illinois State University, sylviafindlay@yahoo.com

Follow this and additional works at: https://ir.library.illinoisstate.edu/etd

Part of the Higher Education Administration Commons

\section{Recommended Citation}

Findlay, Sylvia Miriyam, "An Analysis of Campus Services for International Students at Institutions in the Midwest" (2020). Theses and Dissertations. 1200.

https://ir.library.illinoisstate.edu/etd/1200

This Dissertation is brought to you for free and open access by ISU ReD: Research and eData. It has been accepted for inclusion in Theses and Dissertations by an authorized administrator of ISU ReD: Research and eData. For more information, please contact ISUReD@ilstu.edu. 


\section{AN ANALYSIS OF CAMPUS SERVICES FOR INTERNATIONAL STUDENTS AT \\ INSTITUTIONS IN THE MIDWEST}

\section{SYLVIA MIRIYAM FINDLAY}

\section{Pages}

Higher education campuses are becoming ethnoculturally diverse with the influx of international students from various parts of the world and must modify their international student recruitment and enrollment strategies in response to this trend. The purpose of this study was to examine the perceptions of student affairs personnel to campus services for international students by comparing what should be provided to what is being offered. The study also attempts to identify the gap in their perceptions. Services identified in the literature were examined using the Briggs and Ammigan (2017) collaborative programming and outreach model, which combined concepts of student engagement and experience, intercultural and global competence, assessment and communications, and institutional leadership and support.

The researcher used a quantitative research method based on an internet survey of 272 international student affairs professionals employed at four-year public and private institutions within the 12 states that comprise the Midwest Higher Education Compact. The questionnaire included 21 paired statements describing institutional actions, programs, or services that are designed to help international students. Each pair of statements asked respondents to indicate their level of agreement that the action, program, or service specified in the statement reflects (a) actual practice at their institutions and (b) practice as it should be at their institutions. Responses were analyzed to identify gaps between actual and desired practice. 
Study findings, based on a 54\% response rate, suggest a potentially troubling shortcoming in the extent to which institutions take steps to enhance the intercultural and global competency of faculty and staff. In addition, the study also revealed that respondents perceived gaps in the extent to which their institutions offer semester-long orientations for international students and adequately staff offices that provide services for these students. Study implications are discussed as well as implications for future research.

KEYWORDS: International students, student services, intercultural competency, faculty, staff professional development, training 


\section{AN ANALYSIS OF CAMPUS SERVICES FOR INTERNATIONAL STUDENTS AT \\ INSTITUTIONS IN THE MIDWEST}

SYLVIA MIRIYAM FINDLAY

A Dissertation Submitted in Partial

Fulfillment of the Requirements

for the Degree of

DOCTOR OF PHILOSOPHY

Department of Educational Administration and Foundations

ILLINOIS STATE UNIVERSITY 
Copyright 2020 Sylvia Miriyam Findlay 


\title{
AN ANALYSIS OF CAMPUS SERVICES FOR INTERNATIONAL STUDENTS AT INSTITUTIONS IN THE MIDWEST
}

\author{
SYLVIA MIRIYAM FINDLAY
}

COMMITTEE MEMBERS:

James. C. Palmer, Chair

Mohamed Nur-Awaleh

John. K. Rugutt

Adel Al-Bataineh 


\section{ACKNOWLEDGMENTS}

Trust in the Lord with all your heart and lean not on your own understanding; in all your ways submit to him, and he will make your paths straight. Proverbs 3:5-6

All glory to Jesus Christ who was and is my rock!

This emotional journey would have never been possible without the unwavering support and patience from my family. I thank my husband Shabeer for his unending fun and humor and keeping my spirits up when I was down, and my sons- Shaan and Shamit, who stood as olive trees next to me throughout these years. I dedicate this to my parents Rita and Milton Findlay.

I wish to express my sincere thanks to my chair Dr. Palmer for his meticulous guidance and for always responding to my incessant e-mails. Thank you for agreeing to my chair and believing in me.

I would like to extend my gratitude to Dr. Mohamed Nur-Awaleh for being my mentor for this journey as well as for my professional career.

To Dr. John Rugutt for making statistics easy to understand and enjoyable through each stage of my journey.

To Dr. Adel Al-Bataineh for providing useful guidance that enhanced the quality of my research.

Lastly, I wish to thank all the excellent educators and my cohort colleagues in the higher education program. Every interaction added value and increased my understanding of higher education from an international perspective.

S.M.F. 


\section{CONTENTS}

Page

ACKNOWLEDGMENTS

TABLES

FIGURES - vi

CHAPTER I: INTRODUCTION 1

Research Problem and Questions $\quad 2$

$\begin{array}{ll}\text { Conceptual Framework } & 4\end{array}$

$\begin{array}{ll}\text { Student Engagement and Experience } & 7\end{array}$

Intercultural and Global Competence $\quad 8$

Assessment and Communications Plan 9

$\begin{array}{ll}\text { Institutional Leadership and Support } & 10\end{array}$

$\begin{array}{ll}\text { Study Method and Limitations } & 12\end{array}$

$\begin{array}{ll}\text { Definition of Terms } & 14\end{array}$

$\begin{array}{ll}\text { Summary } & 14\end{array}$

CHAPTER II: LITERATURE REVIEW 16

$\begin{array}{ll}\text { Introduction } & 16\end{array}$

$\begin{array}{ll}\text { Globalization and Internationalization } & 17\end{array}$

Global Student Mobility $\quad 21$

The Role of the United States $\quad 26$

Why Do Students Choose to Study in the United States? 26

What Do They Want to Study? $\quad 28$

The U.S. Market Share $\quad 29$ 
International Student Services

$\begin{array}{ll}\text { Challenges Faced by International Students } & 31\end{array}$

$\begin{array}{ll}\text { Campus Internationalization } & 35\end{array}$

Student Engagement and Services $\quad 35$

$\begin{array}{ll}\text { Intercultural and Global Competency } & 40\end{array}$

Assessment and Communication $\quad 43$

$\begin{array}{ll}\text { Institutional Leadership and Support } & 46\end{array}$

$\begin{array}{ll}\text { Summary } & 48\end{array}$

$\begin{array}{lr}\text { CHAPTER III: RESEARCH METHODS } & 50\end{array}$

$\begin{array}{ll}\text { Data Inquiry Strategy } & 50\end{array}$

$\begin{array}{ll}\text { Designing the Instrument } & 51\end{array}$

$\begin{array}{ll}\text { Study Participants and Procedures } & 60\end{array}$

$\begin{array}{ll}\text { Data Analysis } & 61\end{array}$

$\begin{array}{ll}\text { CHAPTER IV: RESULTS } & 63\end{array}$

$\begin{array}{ll}\text { Participants and Their Institutions } & 63\end{array}$

$\begin{array}{ll}\text { Factor Analysis } & 65\end{array}$

Research Question 1: What Services Do Respondents Perceive that Their Institutions are

$\begin{array}{ll}\text { Providing for International Students? } & 69\end{array}$

$\begin{array}{ll}\text { Student Engagement and Services (SES) } & 69\end{array}$

$\begin{array}{ll}\text { Intercultural and Global Competency (IGC) } & 71\end{array}$

$\begin{array}{ll}\text { Institutional Leadership and Support (ILS) } & 74\end{array}$

Research Question 2: What Services Do Student Services Personnel Perceive That Their

Institutions Should Be Providing for International Students? 76 
Research Question 3: Is There a Gap Between What Services Student Services Personnel

Perceive That Their Institutions Are Providing and What Services Should Be Provided?

Student Engagement and Services (SES)

$\begin{array}{ll}\text { Institutional Leadership and Support (ILS) } & 84\end{array}$

$\begin{array}{ll}\text { Intercultural and Global Competence (IGC) } & 87\end{array}$

$\begin{array}{lr}\text { Summary } & 89\end{array}$

CHAPTER V: IMPLICATIONS AND CONCLUSION 93

$\begin{array}{ll}\text { Faculty and Staff } & 94\end{array}$

Intercultural Competence Training and Curriculum Development 94

$\begin{array}{ll}\text { Students } & 103\end{array}$

$\begin{array}{ll}\text { Student Satisfaction } & 103\end{array}$

$\begin{array}{ll}\text { Semester-Long Orientations } & 103\end{array}$

$\begin{array}{ll}\text { Implications for Future Research } & 106\end{array}$

$\begin{array}{lr}\text { REFERENCES } & 108\end{array}$

$\begin{array}{ll}\text { APPENDIX A: DRAFT QUESTIONNAIRE } & 130\end{array}$

APPENDIX B: MODIFIED QUESTIONNAIRE FOR PILOT STUDY 137

$\begin{array}{ll}\text { APPENDIX C: SURVEY INSTRUMENT } & 143\end{array}$

$\begin{array}{ll}\text { APPENDIX D: INFORMED CONSENT } & 148\end{array}$

APPENDIX E: REFERENCE GUIDE FOR THE STUDY PARTICIAPNTS 152

APPENDIX F: PAIRED STATEMENTS IN SES CATEGORY BY INSTITUTION TYPE 155

APPENDIX G: PAIRED STATEMENTS IN ILS CATEGORY BY INSTITUTION TYPE 157

APPENDIX H: PAIRED STATEMENTS IN IGC CATEGORY BY INSTITUTION TYPE 159 


\section{TABLES}

Table

Page

1. Items in the Initial Draft Questionnaire that were Associated with Each of the Four

Parts of the Conceptual Framework $\quad 53$

2. Distribution of Respondents, by Institutional Type 64

3. Number of International Students at the Respondent's Institutions, by Type of Institution

4. Study Variables Grouped as per the Categories

5. Responses to Actual Practice for Student Engagement and Services Component

6. Responses to Actual Practice for Intercultural and Global Competency Component

7. Responses to Actual Practice for Institutional Leadership and Support Component

8. Responses to The Ideal Situation, by Domain (SES, IGC and ILS)

9. Comparison of Mean "As Is" Responses to "Should Be” Responses: Student Engagement and Services Category

10. Comparison of Mean "As Is" Responses to "Should Be" Responses: Institutional Leadership and Support Category

11. Comparison of Mean “As Is" Responses to "Should Be" Responses: Intercultural and Global Competence

12. Statement Pairs Arranged by Descending Order of Difference of Means 


\section{FIGURES}

Figure $\quad$ Page

1. Conceptual framework for the study, adapted from Briggs and Ammigan (2017) 6

2. Enrollment of non-resident aliens at U.S. colleges and universities, 1976-2017. 27 


\section{CHAPTER I: INTRODUCTION}

The changing landscape of international student migration has affected campus internationalization activities. Higher education campuses, globally and in the United States, are becoming ethnoculturally diverse with the influx of international students from various parts of the world (Ammigan \& Laws, 2018; Choudaha, 2016) and must modify their international student recruitment and enrollment strategies accordingly. Catering to the various needs of these students, accepting their cultural differences, and forming an inclusive environment are essential. Indeed, with disruptive technology and transportation changing our world, international students no longer leave their cultural baggage at the port of entry. Guo (2015) refers to this phenomenon as a product of transnational migration, whereby migrants keep close contact with their countries of origin. That is, international students who leave their countries of origin no longer leave behind their culture but remain connected with their roots. This concept opens a new discussion about campus services for international students, emphasizing the need to question two conventional approaches to working with those from other countries: the "sameness" approach and "difference as a deficit" perspective (Guo, 2015, p.14). Both derive from old mental models of one-way-migration, whereby receiving countries attempt to assimilate migrants as opposed to meeting them halfway, understanding that the host country must adapt to the migrants, just as the migrants must adapt to the host country (Guo, 2015).

Although the literature has offered several recommendations for altering student services to make provision for what international students demand in terms of academic help, social interactions, and cultural acceptance (Alberts and Hazen, 2013; Bista \& Foster, 2016; Gebhard 2010; Jameson \& Loper, 2017), the implementation of the prescribed solutions by American institutions is more or less questionable. There is very little evidence of the extent to which 
institutions of higher education actually provide those services. Accordingly, this study employs a survey of student affairs personnel in the Midwest who work with international students to elicit perceptions of (a) the extent to which their colleges and universities provide services thataccording to the literature - are needed by international students, and (b) the extent to which their institutions should provide those services. An analysis of gaps between what IS being done and what SHOULD be done will suggest how colleges and universities may need to improve the services they provide for international students.

\section{Research Problem and Questions}

The internationalization of American higher education has resulted in increased enrollment of international students, defined as "an individual who has physically crossed an international border between two countries with the objective to participate in educational activities in a destination country, where the destination country is different from his or her country of origin" (UNESCO, 2015). As data from IIE (2019a) Open Doors report indicate, the number of international students on U.S. campuses increased from 690,293 in 2009/2010 to 819,644 in $2012 / 2013$, to $1,043,839$ in $2015 / 2016$ and to a record high of $1,094,792$ in 2017/2018 with a compound annual growth rate 5.26\% from 2010 to 2018 . Many factors have contributed to this increase, including political, economic, socio-cultural, and academic motives (De Wit, 2002). Thelin (2004) deftly traces the history of internationalization in the American higher education system, noting how internationalization, as an initial response to the globalization trend, took on a commercial connotation emphasizing marketing, student recruitment, and, hence, enhanced tuition revenues.

Interestingly, Knight (2004) responded to this by outlining the varying rationales for internationalization, including intercultural understanding among students and faculty; 
development of international, intercultural, or global skills among students, staff, faculty, and administrators; and international strategic alliances that foster research and collaboration. However, Mestenhauser (2006) reiterates that institutions view international students only from an economic rationale, thereby calling for broader thinking among the higher education community in its efforts to internationalize. Higher education leaders need to overcome mental models (Senge, 2006) that view international students only in the context of revenue generation without acknowledging them as critical contributors to the institution and community.

In this context, international students not only contribute to the fiscal health of a university (Knight, 2004) but substantially increase intercultural learning on campus as well as the research and technological capacity of the institution and the country as a whole (De Wit, 2002). However, international students on U.S. campuses face innumerable challenges, including academic, socio-cultural, financial, and language barriers, as well as social stigma (Hayes \& Lin, 1994; Zhai, 2002). As a consequence, a growing body of scholarship (reviewed in Chapter Two) has examined the services these students need. These needed services can be categorized as those that deal with (a) student engagement and experience, such as orientation programs, mental health counseling, mentoring programs and workshops on career and immigration regulations; (b) intercultural and global competency, such as hiring and developing interculturally competent administrators, faculty, and staff; (c) assessment and communication planning, such as datadriven approaches to communication and institutional assessments of campus services for international students; and (d) institutional leadership and support, such as allocating adequate staff and resources for international student services and implementing a comprehensive internationalization plan. 
Nonetheless, the growing body of literature suggesting the need for services has yet to gauge the extent to which colleges and universities provide those services. Accordingly, the purpose of this study is to identify the campus services offered by institutions for international students and elicit perceptions of how services might need to be improved. As explained below, this will be accomplished through a survey of educators at Midwestern universities who are members of NAFSA: Association of International Educators, an organization devoted to advancing international higher education. Members of this organization include educators and administrators (e.g., presidents, deans, faculty, and advisors in higher education institutions) who support the field of international education. The research questions guiding the study include:

1. What services do student services personnel perceive that their institutions are providing for international students?

2. What services do student services personnel perceive that their institutions should be provided for international students?

3. Is there a gap between what services student services personnel perceive that their institutions are providing and what services should be provided?

\section{Conceptual Framework}

The literature on international students establishes the need for a study examining the extent to which services are offered to international students as well as the extent to which institutions foster the intercultural competencies of staff, faculty, and administrators who engage with international students on campus. This exploratory study responds to that need and is based on a questionnaire structured according to a conceptual framework developed by the author through a review of the literature and an adaptation of the collaborative programming and outreach model developed by Briggs and Ammigan (2017). This model assumes that the 
development of services for international students requires a collaborative programming mindset, fosters intercultural and global competence, includes community relations and engagement, enhances the student's experience and engagement, requires strong institutional leadership and support, and is based on clearly defined assessment and communications plans. Apart from these six assumptions, Briggs and Ammigan's model categorizes campus programming initiatives as those that support international student success, assure that students understand government regulations, connect students with the local community, and promote international understanding.

The literature on student services for international students, reviewed in Chapter Two, yielded several initiatives and action plans, which were categorized by the author under four of the six assumptions outlined in the model developed by Briggs and Ammigan: student engagement and experience, intercultural and global competence, assessment and communications planning, and institutional leadership and support. These dimensions encompass the campus programming initiatives that, according to the literature, institutions should undertake for international students. Two assumptions from Briggs and Ammigan model-a collaborative programming mindset and community relations and engagement--do not feature explicitly in this conceptual framework. The collaborative programming mindset calls for institutions to collaborate with wider audiences and other service units on campus, while community relations and engagement entails international students to experience the local community. Both can be subsumed under institutional leadership and support and are a manifestation of the collaborative mindset. According to the Green (2012), presidents hold significant responsibility for spurring increased internationalization activities across the institution, highlighting the vital role of presidential support and commitment to collaborative 
efforts across campus that enhance internationalization. In addition, the interaction of international students with American culture and their involvement in social and business networking eventually lead to career opportunities that foster involvement and engagement along the lines described, for example, by Astin (1999/1984) and by Axelson and Flick (2011). As a consequence, a separate category for community relations and engagement is unnecessary as these activities can be grouped under "student experience and engagement." Thus, four categories, detailed in Figure 1 below, summarize the comprehensive set of services that support international students and serve as a conceptual framework for this study.

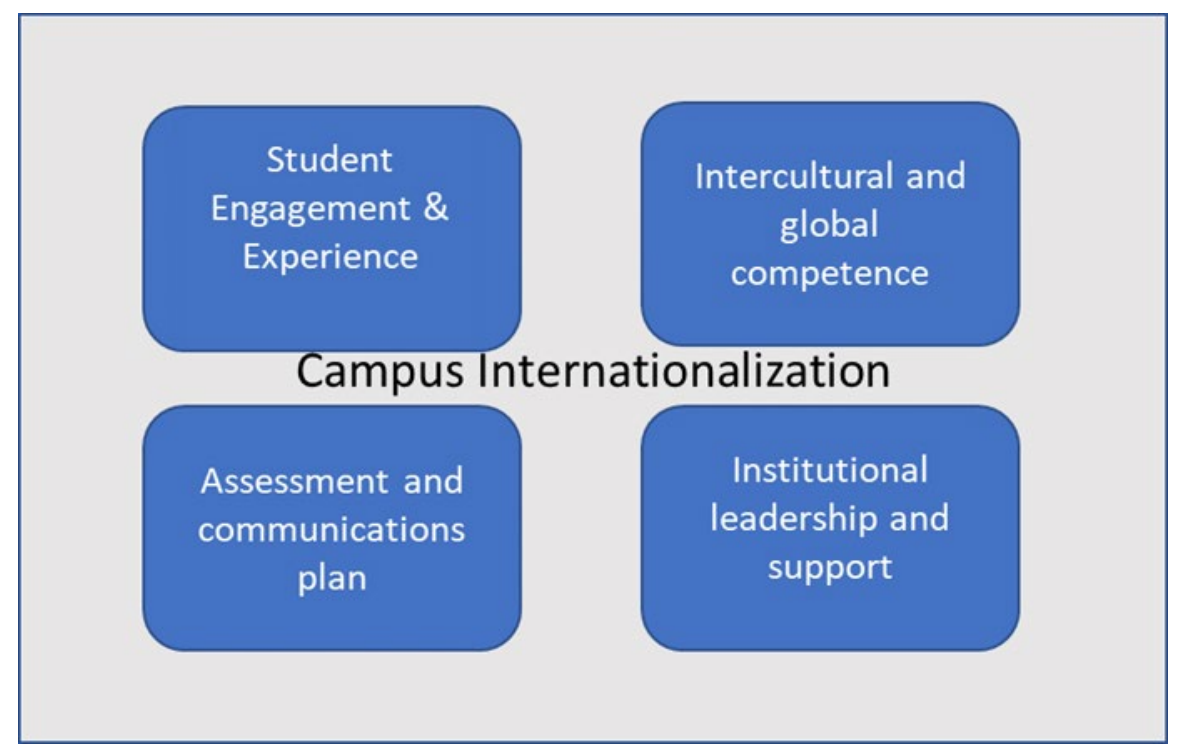

Figure 1. Conceptual framework for the study, adapted from Briggs and Ammigan (2017).

Although scholars have established the need for serving international students, universities and colleges enrolling international students often struggle with inadequate resources and expertise, decentralized services, and an absence of appropriate programs or services that support international students (Bista, Sharma, \& Gaulee, 2018; Briggs \& Ammigan, 2017; 
Choudaha, 2016). Hence, this conceptual framework utilizes four major themes surrounding international student services.

\section{Student Engagement and Experience}

The concepts of student experience and involvement have their origins in the seminal works of Pace (1984) and Astin (1999/1984). From then on, much attention has been devoted to student involvement and student success by prolific authors (e.g., Tinto, 1993; Kuh, 1999; Kuh et al., 2005; Pascarella \& Terenzini, 2005). The literature has taken a two-pronged approach to the examination of student engagement. One group of authors emphasizes what the student does, as evidenced by the time and effort they devote towards their desired college outcomes (Coates, 2007; Kuh, 2009). On the other hand, a report to the Higher Education Funding Council for England (HEFCE) by Little et al (2008) emphasizes what institutions do--the institutional processes and activities that involve and engage students in ways that lead to a better learning experience.

In the context of this study, student engagement and involvement will be viewed from the institutional perspective, emphasizing the processes and activities that institutions employ to alleviate the challenges faced by international students. Faced with financial burdens, sometimes subjected to racial microaggressions, and challenged by the need to adapt to a new culture with different learning styles, food habits, unfamiliar religious affiliations, and more, international students need support in terms of academics, social adjustment, cultural acceptance, and the freedom to study and successfully complete their degrees (Andrade \& Evans, 2009; Bista \& Foster, 2016; Briggs \& Ammigan, 2017; Jameson \& Loper, 2017; Willer, 1992). Scholars recommend various ways to engage and enhance the educational experience of international students, who have taken considerable risks in coming to a foreign country in order to advance 
themselves educationally. These support services, reviewed in Chapter Two, include, for example, student orientation programs, workshops on careers and immigration regulations, and mental health counseling.

\section{Intercultural and Global Competence}

Because intercultural competency has been widely discussed across disciplines, from management (Matveev \& Milter, 2004), to business (Morley \& Cerdin, 2010), and to higher education (Deardorff, 2004; Goode, 2002), the literature yields varying definitions of what intercultural competency entails (Deardoff, 2004). Several authors have added to the knowledge on intercultural competency and its importance in higher education (e.g., Bennett, 1993; Chen \& Starosta,1996; Fantini, 2000). However, most scholars emphasize intercultural competence as a student outcome of internationalization efforts, while others, including Pope and Reynolds (1997), attest to the development of intercultural competency as a critical competency of student affairs professionals. Soria and Troisi (2014) define global, international, and intercultural competencies as "knowledge about several dimensions of global and international cultures; appreciation of cultural, racial, and ethnic diversity; understanding of the complexities of issues in a global context; and comfort in working with people from other cultures" (p. 262). In order to successfully interact with and support students from various cultures and support them towards holistic learning, staff, faculty, and administrators should be trained in and be capable of exhibiting cultural sensitivity. Staff and faculty engaging international students should know that culture and ethnicity are essential parts of an individual's identity and avoid hiding behind the claim of "color blindness" (Chen \& Yang, 2014; Choudaha 2016). Furthermore, staff and faculty should demonstrate cognitive flexibility and adaptability by adjusting to new cultures and behaviors and by embracing an ethnorelative view (Deardorff, 2004). 


\section{Assessment and Communications Plan}

In the wake of global technological advancements, communication preferences among international students are rapidly changing (Ammigan \& Laws, 2018). The literature on international student services recommends an institutional communications strategy and an assessment plan (Briggs \& Ammigan, 2017). Institutions should develop a guiding document for staff, outlining various methods of reaching international students and disseminating timely and useful information. Operating in this era of skyrocketing technological advances, it is easy to assume that everyone, both students and institutional staff and faculty, is comfortable adopting new forms of communication. Complicating this scenario further is the university's reliance on traditional communication methods that do not necessarily align with how the newer generations receive and send messages.

The mindset that all students respond identically to the traditional dissemination of information through e-mails, phones, or flyers prevents student affairs professionals from meeting the unique needs of international students. The responsibility of universities and colleges does not end with relaying messages out to the international student community; institutions must ensure the successful receipt of those messages.

Further, a common thread among many authors in the United States is that assessment revolves around student learning. In other countries, assessments have also focused on analyses of institutional performance in internationalization (Green, 2012). Assessment plans for internationalization in U.S. institutions have traditionally focused on study-abroad programs. According to Palomba and Banta (1999, 2014), a proper assessment must reflect the institutional mission and must be made meaningful. Sound assessments are required for all programs, examining the results of change processes meant to improve those programs as well as the 
impact of the services provided by those programs (Banta, 2002; Bresciani et al., 2009; Grieger, 1996; Pope 1993). According to Perez-Encinas and Ammigan (2016), many U.S. institutions use surveys to gauge student satisfaction, but very few surveys are specifically designed for international students. The International Student Barometer and the National Survey of Student Engagement are among the external surveys' institutions use. However, most institutions find it challenging to find the right survey that caters to their goals of serving international students. Because of the limited options and the cost associated with these external surveys, most institutions develop in-house survey instruments to measure international student satisfaction (Perez-Encinas \& Ammigan, 2016), Without proper feedback, designing new services and modifying existing services is challenging. Thus, it is clear that institutions could respond to the dynamics of campus internationalization through sound communications and regular assessment strategies.

\section{Institutional Leadership and Support}

The literature indicates the importance of an institution's leadership to strategic planning, stakeholder participation, and the allocation of fiscal resources, which are crucial for productive campus internationalization (Davies, 1992; DiMaria, 2012; Ellinghoe, 1998; Grieger, 1996; Knight, 1994). Hudzik (2011) views comprehensive internationalization as the product of a commitment to infuse international perspectives in teaching, research, and service. The author strongly emphasizes the need for institutional leadership and governance to combat deeply entrenched barriers arising from faulty thinking and deficit beliefs that make it difficult for administrators to customize student services for international students. Olson and Peacock (2012) use two concepts: (a) interculturalism, which emphasizes how individuals connect across cultures and encompasses communication and competencies, and (b) grounded globalism, in 
which a geographical frame is applied to elaborate the connections between a global community surrounded by local communities and is connected economically, politically and culturally. These help higher education leaders understand that globalism is grounded in the work of local communities. Rumbley, Altbach and Reisberg (2012) posit that "leaders must be prepared to track and understand the broadest global trends, as well as the internationalization of higher education more specifically, while at the same time attending effectively to the unique needs and aspirations of their particular institutions, local communities, and regional or national contexts" (p.3). Knight (1994) highlights the importance of delineating academic and organizational factors such as policy statements, planning, and review systems in campus internationalization. She recommends a permanent organizational commitment and structure that is underpinned in the organizational culture. Warwick and Moogan (2013) outline several strategic stages for successful internationalization and propose a shift to a student-centered approach that underpins its values on leadership, staff, student communication, organizational development, and locallevel initiatives.

Collaboration among departmental units is considered vital when trying to internationalize the campus. Childress (2009) points out that because higher education institutions typically have several departments and subunits working independently, achieving internationalization through the collaboration of these independent structures is indeed challenging. However, ultimately, the many parts of the college will need to be prepared to meet the needs of international students: academic departments, the registrar's office, health and counseling, career services, the international office, and those units providing help with English language skills. All services will require personnel and budgetary support. And as noted previously, the assumptions guiding the work of those in the organization may need to change. 
Kezar (2001) believes that organizational transformation takes place in higher education institutions when underlying assumptions, behaviors, processes, and structures are profoundly altered across the entire organization. This situation calls for leaders to be "prepared to track and understand the broadest global trends, as well as the internationalization of higher education more specifically, while at the same time attending effectively to the unique needs and aspirations of their particular institutions, local communities, and regional or national contexts" (Rumbley, Altbach, \& Reisberg, 2012, p. 3)

\section{Study Method and Limitations}

This study examines the perceptions of international student services personnel at Midwestern universities, determining the extent to which they perceive gaps between what their institutions do to support international students and what their institutions should be doing to support international students. Identifying these gaps is essential for two reasons. First, international students benefit U.S. higher education institutions, providing needed revenues (Knight, 2004; NAFSA, 2018), enriching the cultural diversity of campus life (De Wit 2002, Knight, 2004; Talbot 2003), and enhancing the competitive advantage of American institutions in the international education sector (Altbach \& Salmi, 2011; Salmi, 2009). Second, although the literature has identified the needs of international students, no empirical studies identify the current status of campus services for international students. An extensive review of student affairs research indicates the dispersed nature of services for international students. International student services are not always centralized under the student affairs department (DiMaria, 2012; Hudzik, 2011). Indeed, international students require services and assistance from a wide variety of departments on campus, including their respective academic departments, faculty members, international student services offices, the library, and offices responsible for admissions, finance, 
housing, and dining. Hudzik (2011) observes, "although sometimes ignored, these offices and programs are in strategic positions on campus to either help or hinder (by omission or commission) facilitating and supporting comprehensive internationalization" (p.21).

Study data will be collected from international student affairs professionals employed at four-year public and private institutions within the 12 states that comprise the Midwest Higher Education Compact (MEHC): Illinois, Indiana, Iowa, Kansas, Michigan, Minnesota, Missouri, Nebraska, North Dakota, Ohio, South Dakota, and Wisconsin. The participants were selected from the NAFSA member directory. NAFSA is the largest association of professionals committed to international higher education. Its members seek to integrate international perspectives in every aspect of higher education and include students and academic researchers, as well as frontline professionals such as presidents, provosts, and deans. This non-profit organization has more than 10,000 members from over 2000 institutions in the U.S. Nonetheless, readers should be aware of the study's limitations.

- The type of institutions, location of the institutions, and characteristics of participants from which data will be obtained limit the generalizability of this study's results. For example, the study does not focus on community colleges, which enrolled approximately $8 \%$ of all international students at American colleges and universities (Institute of International Education. 2020).

- This study does not seek to evaluate the outcomes of the campus services for international students, but merely to examine the current services offered in U.S. institutions in the Midwest. 
- The survey is entirely web-based, and participants without internet access may be inadvertently left out. Furthermore, screen configuration may affect survey layout, and this may affect participation and proper response to the survey.

\section{Definition of Terms}

- International Student: "an individual who has physically crossed an international border between two countries with the objective to participate in educational activities in a destination country, where the destination country is different from his or her country of origin" (UNESCO, 2015).

- International Student and Scholar Office: An administrative unit specifically designed to provide services for international students.

- Intercultural competence: "knowledge about several dimensions of global and international cultures; appreciation of cultural, racial, and ethnic diversity; understanding of the complexities of issues in a global context; and comfort in working with people from other culture" (Soria \& Troisi, 2014, p. 262)

- Student affairs administrators/personnel: An employee under the student affairs department who is not a faculty.

\section{Summary}

This chapter is an introduction to the current research problem, the contextual issues in which the study is grounded, and the concepts around which the study has been framed. The conceptual framework has been derived from the scholarly recommendations for international student support services on American colleges and universities. Findings, based on the perceptions of those who work with international students at public and private four-year institutions, possibly suggest how American colleges and universities may fall short in helping 
these students succeed. The next chapter provides a review of the literature on global student mobility, internationalization, and campus services. 


\section{CHAPTER II: LITERATURE REVIEW}

\section{Introduction}

Amidst the ongoing political changes across the globe, especially with the hostile policies against immigrants instituted by several governments, including the Unites States, the U.S. higher education sector is re-thinking its place in the global education arena. Renowned for "world-class" universities, the major concern now, according to Gluckman (2018), is if the United States is losing its place as the global leader in higher education. Young scholars and others who are passionate about international education in the United States are overcome by anxiety and uncertainty in obtaining vias, as well as by hostile immigration policies. In addition, the academic and non-academic challenges that international students face, including culture shock and transition struggles when moving to the host culture, are well documented in literature. Because of declining enrollments and the fear of losing out in the competition for international students, assuring that international students have a positive experience on campus is critical. This will require U.S. universities to re-examine the experiences of international students, their satisfaction with student services, and campus internationalization efforts generally (Smith, 2020). A critical step involves paying attention to what international students need and catering to those needs, be it in the classroom or across the campus. Understanding the challenges international students experience and then gauging the services that are currently offered at institutions will be key to enhancing the international student experience.

The purpose of this study is to examine perceptions of the gaps, if any, between what campuses actually do for international students and what should be done. Before embarking on the study, a review of the literature is presented in three sections. The first section describes the context in which this study occurs; that is, the globalization and internationalization of higher 
education. The second section examines trends in global student mobility. Finally, the third section explores the academic and non-academic challenges faced by international students. The third part of this chapter also examines the campus services that, according to the literature, contribute to the success of international students while on campus. These recommended actions are at the heart of the survey instrument developed for use in the study.

\section{Globalization and Internationalization}

In a world constrained by borders, globalization has enabled a free flow of people, knowledge, and culture across borders. With technological advancements rendering faster communication and quicker travel, globalization has affected every aspect of the world economy, as well as the political negotiations and socio-cultural exchanges among nations. Its effect has not spared the higher education sector and has spurred nations to educate students about today's shrinking world and view their higher education systems from a global rather than merely local perspective. Altbach and Knight (2007) define globalization as "the economic, political, and societal forces pushing 21 st century higher education toward greater international involvement" (p. 290). Global forces such as the economic interdependence among nations, technological innovations, and scientific trends have impacted higher education institutions (Altbach, 2016; Knight, 2004, Rumbley, Altbach, \& Reisberg, 2012). Rumbley, Altbach, and Reisberg (2012) portray this global environment as "unavoidable" (p. 3), while Green, Marmolejo, and EgronPolak (2012) claim that its intensity will differ by region or country. Huzdik and Stohl (2012) argue that global forces possess competitive and collaborative dimensions. Regardless of nature or the magnitude, a direct result of globalization is open-source knowledge and increased human resource mobility (Marginson, 2011). 
The internationalization of higher education, as Altbach and Knight (2007) define it, is a response to globalization that is evident in campus strategies, policies, practices, and activities. Internationalization is a reflection of globalization within institutional borders. Nonetheless, the literature is fraught with debate about the definition of internationalization, what it must include, and what it should not include. The concept of internationalization is in itself complex. Globalization is a known phenomenon in almost all industries, but both terms (i.e., internationalization and globalization) are often interchanged and confused amongst higher education stakeholders (Knight, 1999; Enders, 2004; Yang, 2002; Stier, 2003). Paige and Mestenhauser (1999) view the internationalization of higher education as the development of a mindset that moves beyond just acquiring knowledge and emphasizes its use as well. As they explain, "it is a way of thinking that integrates and uses knowledge generated in different contexts for the purposes of policy analysis, formation, implementation, and research" (p. 506). However, Knight (1999) provides an additional perspective by stating that "globalization can be thought of as the catalyst while internationalization is the response, albeit a response in a proactive way." Some scholars have elevated the status of internationalization from just a response variable to a more leading variable in globalization; that is, with more and more students and scholars choosing to study outside their home countries, institutions are intentionally engaging in new policies and practices to encourage this trend (Nielson, 2011).

However, again, Knight (2004) goes on to further note that internationalization at the national, sector, and institutional levels "is defined as the process of integrating an international, intercultural or global dimension into the purpose, functions or delivery of postsecondary education" (p.11). As profound as this definition may sound, it raises a fundamental question, "Where do the students factor into this"? The current definitions and understandings of 
"internationalization" exclude a primary constituent of the whole process - students. This narrowness fails to capture the whole breadth of internationalization, focusing on institutional structures, functions, and curricula without considering students .This observation is further bolstered by an historical examination of campus internationalization activities, which are often "numbers-oriented," focusing, for example, on increasing the enrollment of international students or the number of visiting scholars on campus.

Efforts to move beyond numbers by evaluating and assessing the well-being of international students and alleviating their concerns and challenges are less evident. Therefore, there is a need to refine this definition by emphasizing internationalization as a student-oriented phenomenon and not simply a process-focused phenomenon. The student-oriented approach will require institutions to overcome the tendency of taking a reactive rather than proactive approach, responding to queries once the students arrive on campus instead of anticipating them in advance. In addition, institutions need to determine what their responsibilities to students. Qiang (2003) emphasizes that the "approaches" to internationalization fall under four categories: the activity approach, which focusses on curriculum and student-faculty exchanges; the competency approach, which focusses on the development of skills among faculty, staff and students; the ethos approach, which focusses on creating a culture that promotes international or intercultural perspectives; and the process approach, which focusses on integrating intercultural dimensions into institutional processes such as teaching, research, and service.

Ongoing ambiguity in definitions raises the question of what constitutes "internationalization." Scholarly work consists of two sets of divergent thoughts (Yang, 2002). One set of scholars emphasize the importance of international/intercultural dimensions (Knight, 2004), political and economic rationales (Knight \& De Wit 1995), and approaches such as the 
activity approach, the competency approach, the ethos approach and the process approach (Qiang, 2003). On the other hand, scholars also emphasize the activities involved, such as curriculum, English language instruction, international student exchanges, and research partnerships (Knight \& De Wit, 1995; Knight, 2012). Institutions usually focus on the activity approach, emphasizing activities that include, for example, new academic curricula, studyabroad opportunities, and international research partnerships (Qiang, 2003).

Understanding the rationale for internationalization is indeed a crucial maneuver for scholars researching the internationalization of higher education. Internationalization strategies within institutions are dependent upon the institutions' missions and goals. Institutions strategize, design programs, develop policies, and initiate other activities on the basis of what institutional leaders want to achieve. For instance, if the mission of an institution is to increase cross-cultural exchange, then the internationalization activities may be centered on study-abroad programs and increasing international scholar exchange opportunities. However, if the institution's goal is revenue generation, then the focus of internationalization tends to be on increasing international student enrollment. Along these lines, De Wit (2002) distilled the rationales to four specific motives: political, economic, socio-cultural, and academic. Interestingly, Knight (2004) responded by outlining the varying rationales for internationalization, including intercultural understanding among students and faculty, skill development among all actors in higher education, and international strategic alliances that foster research and collaboration. Also, Knights' work in 2012 refined her previous argument, emphasizing two dimensions of internationalization---institutional and national. Every institution's rationale for internationalization varies, and so do the approaches towards internationalization. These 
approaches are governed by their unique ways of defining internationalization based on the institutions' missions and goals.

However, whatever the rationale may be for internationalization, it appears that addressing the challenges and needs of international students has received relatively little attention. Writers who do address these needs and services have tended to engage in four conversations (examined in greater detail later in this chapter): what colleges and universities can do to engage students and enhance their experience, what colleges and universities can do to enhance the intercultural and global competence of international students, what colleges and universities can do to assure meaningful communications with international students, and what leadership and support may be needed to assure institutional capacity to work with international students. As Atebe (2011) says, "successful integration of international students and scholars with the campus and its domestic students is the key to effective internationalization efforts" (p.1). Students are the heart of campus internationalization. Accordingly, using the definitions offered by Knight and Atebe, internationalization in this study will be defined as leveraging international, intercultural, or global dimensions of campus life in ways that lead to the successful integration of an institution's international students and scholars with its domestic student body and faculty.

\section{Global Student Mobility}

Globalization has enabled a substantial number of students to move across the globe to further their education. According to UNESCO (2017), the number of international students pursuing postsecondary education more than doubled from 2,0 million in 2000 to 5.3 million in 2017. International student migration takes many forms, varying, for example, by the length of stay (e.g., short term, long term) or by who is involved (e.g., dependents of temporary or 
permanent workers, or asylum seekers). Over the last 20-30 years, the migration of international students has changed both in terms of magnitude and pattern. Changing patterns of student mobility reflect shifts in student choices of study destinations, the greater dispersion of students across more countries, and the movement away from traditional host countries. These changes have fostered increased competition among nations, governments, and institutions for internationally mobile students.

One major trend observed in international student migration is that students are intentionally moving away from traditional destinations to newer countries. The top destinations for international students (i.e., the United States, the United Kingdom, Germany, France, and Australia) have experienced tremendous competition from other countries and, consequently, their hold on attracting international students has steadily declined. These host countries attracted $75 \%$ of the international students in $2001,63 \%$ in $2006,56 \%$ in 2011 , and $46 \%$ in 2017 (NAFSA, 2018). Choudaha (2017) posits that international student mobility occurred in three waves. Wave 1 (1999-2006) was fueled by growing labor market demand for skilled workers in the STEM fields. In addition, the Bologna process helped streamline the educational process by recognizing credentials and harmonizing tertiary educational standards across Europe. This increased student mobility within Europe, bringing in students from the non-European Higher Education Area. According to Choudaha, Wave 2 occurred between 2006-2013 during the global financial crisis that hit the Western world. Western countries are traditionally the host countries for students moving from the East. In the wake of the financial crisis, The United States and other western countries increased the recruitment of international students as a way of sustaining revenues, and opportunities for students in Asia and the Middle East increased. For example, the Saudi Arabian government offered scholarships for students to study in the United States. At the 
same time, the middle class in China experienced more power and opportunity and started sending more students over to U.S. institutions. This wave was marked by self-funded students and an increase in undergraduate international students. The third wave happened between 20132020, as major global events changed the political picture of many countries. The United Kingdom's exit from the European Union ("Brexit"), the Trump era in the United States, the Trudeau era in Canada, the crash of international education "industry" in Australia, and the economic slowdown in China have all changed the trajectory of international student migration. The increasing xenophobic policies and intolerance to immigration propagated by the Trump administration and reflected in Brexit consequently harmed international student migration (Gaulee, Sharma \& Bista, 2020).

International students are now empowered to choose a wider range of destinations and are not confined to the traditional host countries such as the United States, the United Kingdom, Australia, or Canada. Asian and Eastern European countries have taken advantage of the global political climate and are creating regional "hubs" (Knight, 2011b). The emergence of regional hubs has contributed most towards the decreasing trend in international students choosing destinations other than the traditional host countries. These regional educational hubs consist of science and technology centers, research institutes, and other educational settings that are designed to attract top talent. Regional hubs emerged in 2010 as a response to the "brain drain" as the United States, the United Kingdom, and Australia attracted the best minds and talents and thereby diminished the workforce quality of sending countries. Several regional hubs have sprouted in the last few years, especially in Asia and the Middle East. In addition, several other countries, including Vietnam, India, Russia, and Brazil, are also clawing their way toward academic supremacy by creating educational hubs (Guruz, 2011). The United Arab Emirates, 
South Korea, New Zealand, and Singapore are emerging as popular destinations for international students as they have invested in world-class research and educational settings designed to attract and retain international talent aiming to develop the knowledge economy in those countries (IIE 2019b). For instance, according to the IIE (2019b), Korean institutions have seen a substantial increase in the enrollment of international students, from only 1,983 students in 1995 to 90,000 students in 2011 and 123,850 students in 2017. South Korea has instituted "Brain 21 Korea," an initiative to grow highly qualified human resources for the 21st-century's knowledge-based society (Gaulee, Bista \& Sharma, 2020). Similarly, Malaysia, Singapore, and New Zealand have attracted a substantial number of international students, each enrolling about 60,000 students in 2017 (IIE 2019a; IIE 2109b).

Although international student migration started with "massification" (i.e., the transformation of higher education from an elite enterprise serving a relatively small proportion of the population to an enterprise that serves even broader segments of society), nations have shifted from recruiting a substantial number of students to selectively recruiting top talent and focusing on the "quality" of international students (Altbach, 2016; De Wit, 2015). Given the urgent need to churn out high-quality research and to publish globally valued research papers, institutions search for the top talent among international students. According to Knight (2011b), while developing a knowledge base, institutions focus not only on international students, but also on the recruitment of scholars, faculty, and researchers across geographies, thereby making these regional destinations even more attractive for international students. The rise of the hubs reflects a shift in governmental focus from expanding higher education access to increasing the international standing of the country's higher education system. Scholars attribute the development of hubs to competition for academic supremacy (Altbach \& Salmi, 2011; Salmi, 
2009). Lane and Johnstone (2011) point out that these regional hubs have been heavily subsidized by the countries in which they operate and that since the early 2000 s, government policies, measures, and initiatives in these countries have vied to enhance their global standing in international education. By developing free economic zones, research institutes, and international cities, these regional hubs are designed to increase "brain gain" and attract top international students and scholars.

The development of regional hubs leads to another noticeable trend: intra-regional mobility among international students. Students preferring global education are turning towards world-class research centers and educational institutions that are close to their countries of citizenship. For example, students in Asian countries often choose study destinations within Asia, and, likewise, those in Europe often choose to study in European countries. According to ICEF monitor, international students from nearby Asian countries such as China, Vietnam, Mongolia, and Uzbekistan, have been increasingly choosing Asian regional hubs for their higher education needs. UNESCO's (2015) data indicate that the proportion of international students from Asia who choose to study in Asian countries rose from 36\% in 1999 to $42 \%$ in 2007. The same upward trends can be seen among Latin American students; in 2007, 23\% chose to study within their region, compared to $11 \%$ in 1999. Similarly, the volume of global research output in terms of publications and collaborations in European higher education systems in countries such as Switzerland, Denmark, Austria, and Germany has resulted in increased student flow across European countries as demonstrated by the ERASMUS program, which enrolled about 300,000 international students in 2014, of whom 23\% were from the southeast European region (Bona \& Ferrari, 2017). 
Countries traditionally sending international students have also experienced a shift in the last decade, with countries in Africa and the Middle East joining the list. Recently, a more significant influx of students from the Middle East, especially Saudi Arabia, and unprecedented growth of outbound African students from Nigeria, Cameroon, Morocco, Kenya, Zimbabwe, Angola, Ghana, and Algeria has been noticed. African students pursuing postsecondary education rose by $24 \%$ from 2006 to 2014, with around 430,000 international students going to France, the United States, the United Kingdom, Germany, Malaysia, Canada, and other countries in 2014 (Schulmann, 2017). The increased competition for international students will require U.S. institutions to do more to position themselves as destinations of choice for international students.

\section{The Role of the United States}

The United States has been at the center of international education and has exerted a strong influence on the educational community worldwide. However, its past dominance in attracting international students has led to complacency, and the U.S. risks losing its marketleader position to other countries. Serious consequences to the economic and technological competitiveness of the U.S. are likely to follow if attention is not directed at keeping up with a dynamic global market for international students. This section examines what we know about international students in the United States, the reasons they choose to study in the U.S, and what they study. Implications for campus internationalization are then discussed, paving the way to an analysis of campus student services for international students.

\section{Why Do Students Choose to Study in the United States?}

High-quality education, technological supremacy, and strong career opportunities are the primary reasons international students choose the United States as a top destination for study. As 
a provider of world-class education, cutting-edge technology, and dynamic research opportunities, the United States has been a leader amongst other developed countries as the first choice and preferred destination for international students. Although growth in the overall enrollment of international students at U.S. colleges and universities has tapered off since 2015 (Figure 2), the United States remains among the top destinations of those seeking educational opportunities outside of their own countries. Pull factors such as global university rankings, STEM degrees, and career opportunities have drawn international students towards highly prestigious institutions, as evidenced by the enrollment of universities worldwide (Hazelkorn, 2012). According to the 2017 Quacquarelli Symonds world university rankings, 41 U.S. universities featured in the top 100 universities globally (QS WUR, 2017). U.S. universities have built strong reputations in research, teaching, technology, and innovation, and therefore they are still coveted by international students.

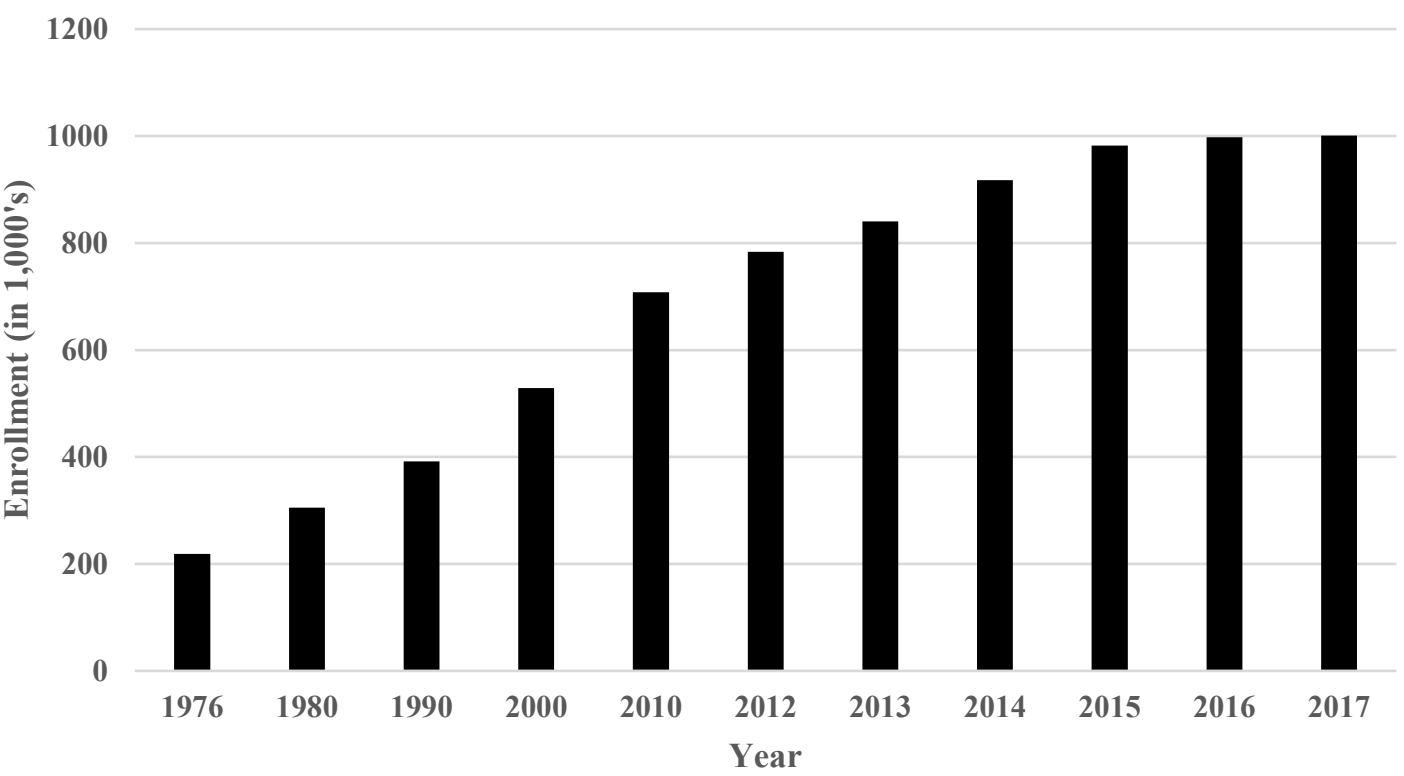

Figure 2. Enrollment of non-resident aliens at U.S. colleges and universities, 1976-2017. Source: National Center for Education Statistics (2018). 


\section{What Do They Want to Study?}

Willer (1992) observed that international students tend to choose business and management, science, and technology as their top fields of study in the United States. Students from China, India, and other Asian nations are particularly interested in fields related to science, technology, engineering, and math (STEM) (IIE, 2019b). Asian countries, especially India and China, have remained the heavyweights in sending students out to the United States, with $52 \%$ of international students coming from these countries as of 2017 (IIE, 2019b).

International students view studying in the United States as a prestigious opportunity that results in enhanced entrepreneurial and work opportunities (Willer, 1992). The demand for STEM degrees has been propelling international student enrollment at U.S. institutions. The attendant benefits of STEM degrees, such as obtaining a work visa, a path to citizenship, and a high-paying career, have been identified as the key reasons why international students choose to study in the United States (U.S. Bureau of Labor Statistics, 2019). The Bureau of Labor Statistics (2019) predicts a robust growth of $8.8 \%$ in STEM occupations over the next ten years to 2028 . STEM doctorates earned by international students at U.S. institutions have increased at a rate of 2\% annually from 1975 to 2015, with China, India, and South Korea accounting for more than half of the STEM doctorates from 2005-2015 (National Science Foundation, 2015). These statistics demonstrate the importance of STEM education to international students. The growing number of students earning STEM credentials in the United States represent a talented human resource capable of enhancing the nation's economic growth, given the tendency of corporations and businesses to favor graduates with STEM degrees (NAFSA 2018; NAFSA 2019b) and the premium government policymakers place on the importance of growing their economies and encouraging innovation. 
Declining stay rates of international students after graduation in the United States are a disturbing phenomenon that affects the nation's technological competitiveness. The growing number of students opting to leave the United States after their studies, either returning to their home countries or emigrating to other countries, is detrimental to the U.S. economy. Han and Applebaum (2016) posit that the stay rate of international students declined from $71 \%$ in 2001 to $66 \%$ in 2005. The rate further declined to 64\% in 2011 and 48\% in 2014 (Han \& Applebaum, 2016). If these graduates leave the United States, then the technological growth fostered by these STEM graduates in terms of start-ups and innovations would be affected (NAFSA 2019b).

NAFSA (2018) emphasizes the importance of international students to the U.S. economy, showing international students have contributed $\$ 39$ billion to the U.S. economy and have supported 455,000 jobs in 207-2018. International students, especially those earning doctorates with a STEM focus, constitute a significant factor in the U.S. maintaining its intense research and technological supremacy.

\section{The U.S. Market Share}

Despite having high-quality education, research, and technological supremacy, the U.S. market share of international students is eroding. The growing competition among countries for international students, as well as the unsettling political climate in the United States and the negativity surrounding U.S. immigration laws, have impacted the enrollment numbers of international students in U.S. higher education institutions (Redden, 2018). According to NAFSA (2019a), in 2001, the United States attracted 28\% of international students globally, but this declined to $22 \%$ in 2018 while the proportion of international students attending higher education institutions in the United Kingdom, Germany, France, and Australia increased. Also, with the recent political climate, international student enrollment in the United States has 
dropped significantly. In 2017, the overall international student enrollment in the United States declined by $4 \%$ over the previous year (Anderson, 2018). In contrast, Canada experienced a 22\% increase in the enrollment of international students between 2015-2016 and 2016-2017 (Canadian Bureau of International Education, 2018), and Australia registered gains of 4\% in 2019 when compared to its share in 2001 (IIE 2019b).

Immigration policies and initiatives are not sufficiently conducive to keeping the best and the brightest of these graduates in the United States. These policies have reduced the number of temporary work visas in the United States as well as the number of employment visas (Anderson, 2018). Also, reductions in the number of post-completion optional practical training (OPT) visas have impacted student decisions to choose the United States when determining where to go to college, as witnessed by the decline in students entering the United States in 2016-2017 (Anderson, 2018).

\section{International Student Services}

Much of the conversation on international students studying in American colleges and universities focuses on their experiences, the challenges they face, and the barriers to transnational migration (i.e., the process by which immigrants and the countries they immigrate to adapt to each other). In contrast, relatively little has been written about institutional services for these students. In the last decade (2009-2019), the challenges faced by international students and identified in the literature are many and varied, relating to themes such as adjustment, satisfaction, learning, social media, discrimination, class participation, and post-colonial narratives (Raby \& Zhang, 2020). This complicates the university's role in providing services that help international students as these challenges identified in literature, according to Raby and 
Zhang, 2020, are quite varied. Therefore, this chapter examines those challenges and the services that have been employed to address them.

\section{Challenges Faced by International Students}

As impressive as the strengths of the United States are in attracting international students, patterns and trends in student migration show a decline in enrollments of international students U.S. colleges and universities. American institutions are now tasked to ramp up their campus internationalization initiatives, including the expansion of carefully designed student services that address the challenges of diverse student populations. The literature examining international student experiences in American institutions refers to the many challenges these students face while they pursue their higher education degrees. Despite the varying themes in international student challenges, the challenges faced by international students living and studying in the United States can be loosely categorized into four domains: academic, social, financial, and cultural (Hayes \& Lin, 1994; Zhai, 2002).

Academic issues are by far the most intimidating for students on campus. Insufficient English language proficiency makes it difficult for international students to seek help from faculty and fellow students, as do classroom learning norms and faculty-student interactions that are different from those that the students are used in their home countries (Smith, 1999). These issues arise for international students, even if they are motivated to study in an unfamiliar environment. Students prepare themselves for academic expectations, including reading, writing, and classroom participation, even before they arrive in the United States. However, they often overestimate their proficiency. They have academic challenges, especially in speaking and group work that requires critical thinking skills (Andrade \& Evans, 2009). Bista and Foster (2016) further attest to the academic challenges of international students for whom time management, 
dueling agendas, and socioeconomic struggles are real. Differences in educational systems, learning styles, English language proficiencies, teaching styles, and course content have contributed to stress and anxiety among these students (Alberts \& Hazen, 2013; Bista \& Foster, 2016; Gebhard, 2010; Trice, 2003).

English language proficiency has been an essential factor in academic success (Zhai, 2002), and several authors attest that the learning experiences would be much less stressful with a better command of the language. As more students with limited English language proficiency enter the United States, the need for better-prepared teachers also increases (Zhao \& Ng, 2016). Halic, Greenberg, and Paulus (2009) concluded that non-native-English-speaking graduate students perceived English as both a barrier and a channel of access. Students consider English as a barrier for freely expressing their feelings, or effectively participating in classroom discussions. However, students consider command of the English language as a way of providing them with access to other cultures (not only the American culture) and facilitating conversations that will help them share their cultures with others. Halic, Greenberg, and Paulus recommended that educators who work with non-native, English-speaking international students address "not just the academic but also relational and affective issues" (p. 92). Li et al (2016) posit that the formation of academic subcultures among southeast Asian students limited interactions with faculty and other domestic students. Faculty mentoring, teaching, and classroom expectations in these settings reflect the intercultural competencies of administrators, faculty, and staff who engage with international students. Lee and Metcalfe (2017) claim that the qualification and experiences of academic advisors are critical, as these professionals must act "with a thorough and deep understanding in culture, history, and the current sociopolitical situation of the advisees in mind and treat each case individually" (p. 956). 
International students struggle in a new country, not knowing how to balance personal life and studies. Jameson and Loper (2017) suggest that because international students view the university campus through their own cultural lens, several adjustment issues arise. Harwood and Petric (2017) assert that "some students experience profound emotional highs and lows" (p. 187) as they are unable to manage their daily schedules, personal commitments, or their social life. Balancing academics, social life, and cultural differences in a foreign land requires time and management skills that are often challenging for international students (Alberts \& Hazen, 2013; Paton, 2007).

Financial issues pose a significant challenge for many international students. They have to pay full tuition costs, regardless of the type of institution they attend, in addition to other expenses during their stay in the United States. The tuition-fee price differential for international students affects their decisions about studying in the United States. Even though community colleges are less expensive than four-year institutions, international students are charged the full fee. Some international students in community colleges are afraid to transfer to a four-year institution because of the cost (Anayah, 2012). In addition, currency conversion rates may double or triple the tuition fees in comparison to those changed in their home countries. If the currency devalues in their home country, the students undergo undue stress and hardship. For instance, Turkish Lira crashed against the U.S. dollar in July 2018, causing tremendous stress for Turkish students studying in the United States (Pacheco, 2020). Likewise, the Indian government demonetized the highest value banknotes in 2016, resulting in utter chaos and stress for Indian students and their families. These students depend on financial sources from home, and any delay in receiving the money causes them undue tension. Furthermore, health insurance costs are high for international students. (Sherry, Thomas \& Chui, 2010). 
Social and cultural issues are common among international students. These include language barriers, social stigma, and racialization. Cultural differences not acknowledged by the domestic students and even by some administrators have been explored in detail by Andrade and Evans (2009). Drawing on the importance of social integration propounded by Astin's (1999/1984) developmental theory of student engagement, the authors examine the importance of social interactions for international students. They say that because international students are socially challenged due to language insufficiencies and cultural differences, social integration is much more complicated than for domestic students. Gebhard (2010) illuminates the myriad issues faced by international students in the United States, including difficulties in social adjustment that result in frustration, anger, confusion, homesickness, and depression. Loneliness, isolation, and mental health problems are common for students living away from their families (Alberts \& Hazen, 2013; Bista \& Foster, 2016; Willer, 1992).

Regarding these cultural differences as deficits, many administrators focus on helping international students assimilate into the U.S. culture rather than encouraging them—along with U.S. educators - to share their cultures and educate each other (Guo, 2015). For example, international students feel comfortable staying with someone from their own country, but residential requirements may force them to be paired with domestic students as a way of assimilating them to U.S. culture (Tolman, 2017). This practice creates tension, stress, and homesickness as international students are not prepared to instantly let go of their cultures when they enter the United States. This further complicates the socio-cultural challenges experienced by international students on campus. International students also experience racial prejudice (Albert \& Hazen, 2013; Bista \& Foster, 2016). Preconceived racial images, racial hierarchy, and negative racial attitudes towards certain ethnic groups are compounded by media portrayals, a 
lack of interaction with members of other racial groups, and an unawareness of unintentional racist attitudes.

Cultural differences, such as those related to food preferences, language, learning styles, and prior work experiences, are not always taken into consideration when colleges plan services for international students. For instance, international students from the Middle East may find it daunting to work with the opposite gender, or Asian students might struggle to talk out loud in class (Albert \& Hazen, 2013), or Muslims students might not find a place to pray or access Halal food (Bilas, 2014). Failing to recognize these sorts of cultural differences impedes cultural diversity on campus, creates a dissatisfied student community, and hinders student success. There is a need for experienced staff who know how best to advise students with varied backgrounds.

\section{Campus Internationalization}

In effect, it is evident that the challenges faced by international students will continue to persist unless acted upon with efficient campus internationalization initiatives led by interculturally competent administrators, faculty, and staff. Scholars have pointed to these challenges as indicators of a need for comprehensive student services on campus.

\section{Student Engagement and Services}

Campus services to engage international students should be sensitive to their needs. Although international students do not always value campus life activities such as athletics and student activities (Bista \& Foster, 2011), focusing instead on academic or legal matters, Bista (2015) argued for the importance of international programs, student organizations, career centers, and health centers that address the needs of international students specifically and not only the 
needs of domestic students. Student services should take into account the needs of international students from the perspective of transnational migration.

Scholars have identified a range of student services to alleviate the struggles of being a student in an alien place. These services include academic writing workshops (Alberts \& Hazen, 2013; Bista and Foster, 2016; Gebhard, 2010; Trice, 2003), mental health counseling (Mori, 2000), career services that help students find internships and jobs (Mcfarlene, 2015; Roy, Lu \& Loo, 2016), increased student-faculty interactions (Girmay, 2017), and efforts to support religious and cultural connections (Jenkins \& Galloway, 2009; Özturgut \& Murphy, 2009). Furthermore, orientation programs provide international students with information about academics, as well as social and cultural differences. The importance of orientation has been stressed by several scholars who note that that the struggles of international students can be alleviated by organizing pre-arrival orientations even before students leave their home countries (Arshakian \& Wang, 2017), post-arrival orientations (Olivas \& Li, 2002), and in-depth academic orientations (Zhai, 2002). Transition support programs, extended, semester-long orientations, and first-year experience programs are also important (Briggs \& Ammigan, 2017).

A recent study by Lértora, Sullivan, and Croffie (2017) showed that international students felt that organizational support should be "informational, emotional, tangible, and intellectual" in order to help them on campus (p. 2). Support services such as orientations provided both before the students leave their home country and upon arrival on campus also contribute to student success (Arshakian \& Wang, 2017). An example can be seen in pre-arrival webinars that educate parents and students about admission requirements, required visa documents, and what students can expect once they reach the United States. Jennings (2017) attests to the importance of preparing students for visa interviews through adequate information posted on websites. The 
author urges colleges to develop strong relationships with visa consular officers in promoting the value of American colleges. In addition, a strong student affairs team can help international students overcome challenges faced during their transition period. For example, they can conduct orientation programs (Olivas \& Li, 2002) on arrival to educate students on the American educational system and the services available on campus.

Flexible counseling services, including mental health counseling and mentoring programs, are ways to enhance the experience of international students. Such support, especially for international students suffering from social stigma, racialization, isolation, and stress, can be made possible only if the student affairs team is aware of the issues that students experience and chooses to act on them. Furthermore, Mori (2000) attest to the taboo associated with mental health counseling among many international students preventing them from accessing those services on campus. Yeh and Inose (2003) recommend mental health counseling that is grouporiented and focused on social connectedness to help the international students overcome their reluctance in accessing these counseling sessions. Also, research attests to providing religious support for international students and their families as a way of alleviating mental stress and helping them cope (Bilas 2014, Jenkins \& Galloway, 2009)

Discussions of campus services for international students often neglect an important stakeholder group--the faculty. Student services on campus are usually targeted towards the nonacademic needs of the students, both domestic and international. Rarely do administrators consider training or equipping faculty to address the academic issues faced by international students. Kisch (2014) proposes orientation workshops and training for faculty and staff, emphasizing how they can interact with students in a culturally sensitive manner. The literature highlights the importance of faculty for international students, especially for graduate students, 
as they tend to rely more on the faculty advisors than their domestic counterparts $(\mathrm{Ku}$ et al., 2008; Schinke, da Costa, \& Andrews, 2001). Though several factors that contribute to academic difficulties have been identified, only a handful of studies address the challenges faced by faculty members who teach these students. There is a need to educate the faculty so it can better meet the needs of international students, bridging differences in learning styles and cultural backgrounds (Bichelmeyer \& Cagiltay, 2000). A lack of international consciousness and involvement (Altbach \& Peterson, 1998) poses serious challenges for faculty teaching international students. A pivotal study by Trice (2000) showed that although faculty members attempted to support international students not only as faculty but as advisors and research supervisors, they were often unable to do so effectively because of inadequate funding and a lack of formal policies on course restructuring and English language requirements. The author recommends that departments forge stronger linkages with English language centers, teaching and learning centers, domestic and foreign student representatives, and the international student center so faculty can understand what the international students need and thus navigate the cultural differences between them and the students they serve. Several scholars recommend incorporating formal policies that equip faculty to implement innovative classroom teaching strategies and be culturally sensitive during academic advisement; examples of such policies include project-based classroom teaching, mentoring opportunities, and interacting or connecting with students outside the classroom to offer informal advising sessions (Amirali \& Bakken, 2012; Lee \& Metcalfe, 2017; Mcfarlene, 2015). The academic challenges faced by international students can be exacerbated by ill-equipped faculty. Sufficient training that will help faculty members develop intercultural competencies and customize classroom teaching strategies are crucial to enhancing the academic experience of international students on campus. 
Although several authors have recommended "best practices," few of these discussions, outside of three notable case studies, are based on research. These case studies focus on concrete initiatives to address specific student challenges. An example is the University of Oregon's International Cultural Service Program that engages international students in an attempt to build the intercultural competency of native students (Briggs \& Ammigan, 2017). In this case, the students are used as an instructional resource, and they receive tuition assistance for their participation. Another example is the successful career services program at Michigan State University that provides workshops to help international students navigate the complex job market and update them on immigration news, communication skills, and resume building (Michigan State University, n.d.). Another example stems from the work of Spencer (2016), who examined the impact of orientation and first-year programming to help in the transition of international students and support them through the adjustment process. Student services programming should train staff, faculty, and administrators to better engage international students. Furthermore, the support services should be designed to address U.S. immigration requirements, the academic demands students will face on U.S. campuses, the social integration of international students, their health problems, and the strategies that will help international students achieve their career goals.

To summarize, the literature suggests the following as important services that enhance the engagement of international students on campus:

- pre-arrival orientation programs, post-arrival orientation, transition support programs, extended semester-long orientations, and first-year experience programs;

- academic orientations;

- flexible counseling services; 
- mentoring programs;

- career counseling;

- workshops to inform students of available campus services, including mental health services and information on U.S. visa and immigration regulations;

- learning and development activities offered through student clubs and organizations;

- the development of religiously affiliated centers;

- formal policies that equip faculty to implement innovative classroom teaching strategies;

- opportunities for faculty and students to connect outside the classroom; and

- writing support.

\section{Intercultural and Global Competency}

One cannot dismiss the compelling need for interculturally competent staff, faculty, and students in U.S. higher education institutions, given the tremendous demographic shift caused by global student mobility. Intercultural competency, according to Fantini (2006), is "a complex of abilities needed to perform effectively and appropriately when interacting with others who are linguistically and culturally different from oneself" (p. 12). Scholars have discussed intercultural competencies using various models as well. Chen and Starosta's (1996) model of intercultural communication competence, as well as the model developed by Bhawuk and Sakuda (2009), note that intercultural competency involves cognitive, affective, and behavioral learning processes. Despite the differences in the terminologies used in discussions of intercultural competence (e.g., multiculturalism, global competency, etc.), the literature has long advocated for intercultural competence among student affairs professionals to engage today's increasingly diverse, international student population. 
Because the needs of international students may, in many cases, be different from those of their domestic counterparts, culturally sensitive approaches are deemed necessary. Choudaha (2016) advocates for an inclusive campus environment with interculturally competent stakeholders, including faculty, administrators, and students. Hoekje and Stevens (2018) recommend that institutions hire advisors who reflect the diversity of students or at least train advisors to work with multicultural students. Hence there is a need to hire, prepare, educate and develop culturally competent student affairs administrators, attention to which may decrease the incidence of microaggressions towards international students (Harwood et al., 2015). Onyenekwu (2017) emphasizes that "Student affairs professionals should be prepared and culturally competent to help mitigate misunderstandings and facilitate intercultural and inclusive dialogue" (p. 1122).

Furthermore, culturally responsive programming and services that specifically address the needs of international students, instead of blanket services for all students, are essential (Briggs \& Ammigan, 2017; Pope \& Reynolds, 2009). Effective implementation of these services demands interculturally trained staff (Chen \& Yang, 2014; Choudaha, 2016; Koseva (2017) and faculty (Smith, 1999) who are sensitive to the cultural differences brought by international students in the classrooms, residence halls, cafeteria, and everywhere on campus. Furthermore, the importance of intercultural training for faculty is bolstered by Bennett and Bennet (2004), who indicates that faculty require international practicums or exchange experiences if they are to understand the cultural points of view of the international students and, as a consequence, enhance their classroom experience. Lee and Metcalfe (2017) recommend that colleges provide academic advisors with professional development opportunities abroad. Additional methods of enhancing intercultural competencies have been outlined by Pope and Reynolds (2009), 
including the infusion of intercultural content within the curriculum, the implementation of continuing education programs for staff and faculty, and the employment of multicultural competencies as criteria in the performance evaluation of employees.

Deardorff's (2006) proposed intercultural competency model emphasizes that attitude is the baseline for intercultural competency. This framework also illustrates that intercultural competence must be intentionally addressed. Therefore, developing an individual's intercultural competency relies primarily on institutional leadership, culture, and processes. Presumably, the ways leaders address the culture and processes of an institution hold critical implications for professional training and development that will strengthen international student services on campus. Based on the literature, the following recommendations will help higher education institutions develop the intercultural competence of faculty and staff, enabling them to address the needs of international students better:

- hire advisors who reflect the diversity of students;

- train or equip faculty to address the academic challenges faced by international students, including classroom teaching techniques and learning styles that they may not be familiar with;

- offer academic advisors professional development opportunities abroad;

- train advisors to work with international students;

- develop culturally responsive programming and services;

- assure that staff, administrators, and faculty are interculturally trained;

- infuse the curriculum with intercultural content;

- implement continuing education programs for staff and faculty; and

- establish multicultural competencies as part of the performance evaluation of employees. 


\section{Assessment and Communication}

International students are often intimidated by the unfamiliar environment, people, culture, and activities that they encounter on campus. In addition, they have several unanswered questions, and they struggle for help in a student service environment that often treats all students the same. The mindset that all students respond identically to traditional methods of disseminating information (e.g., e-mails, phone calls, or flyers) prevents student affairs from meeting the unique needs of international students. One-on-one meetings, surveys, and group discussions can help administrators learn about the unique needs and challenges of the international student community.

Effective communication is crucial in reaching out to these students, who may differ culturally in ways they communicate. Özturgut and Murphy (2009) made an important observation that supports this argument, noting “... the lack of direction and focus from the U.S. institutions of higher education in making individual connections through effective communications." Analytics-driven communications strategies (Ammigan \& Laws, 2018), such as surveys that elicit the communication preferences of international students, are required at institutions. Ammigan and Laws (2018) assert the importance of optimizing communication strategies in coordination with other institutional departments to enhance the experience and success of international students.

Developing organizational learning communities in institutions is a crucial step towards campus internationalization. Dowd (2007) references the work of Bensimon, Polkinghorne, Bauman, and Vallejo (2004) in fostering organizational learning in community colleges that will emphasize the role of student affairs professionals as active researchers. The "practitioner-asresearcher" model propounded by Bensimon, Polkinghorne, Bauman, and Vallejo, not only 
closes the gap between researchers and practitioners but also increases administrator and leader awareness of various issues such as communication preferences of international students, their preferred mode of communication, the frequency of communications from the university, their satisfaction levels with those communications, and any cultural dissonance or lack of collaboration they encounter within units in the organization. Practitioner-led research can lead to a greater awareness of student challenges and needs, leading to the improvement of campus services.

The practical knowledge obtained through these inquiries will help organizations initiate concrete action plans that mitigate the challenges experienced by international students. For instance, it is known that international students struggle with limited language proficiency (e.g., Andrade \& Evans, 2009; Halic, Greenberg, and Paulus, 2009). However, administrators and student affairs staff must be aware that this problem exists in their organization. A simple survey of the faculty and students would help them gauge the extent of the problem and implement solutions such as tutoring or writing workshops.

A common trend among U.S. institutions is achieving institutional strategic goals through internationalization. Assessment plans for international programs in U.S. universities have traditionally focused on impact of study-abroad programs on student learning (Paige, Cohen \& Shively, 2004). Institutions must, therefore, be cautious in implementing the internationalization of campuses, questioning why this internationalization is necessary and how it contributes to the institution's broader goals. The impact of internationalization is often missed when the focus shifts from the big picture to the implementation of day-to-day tasks. Braskamp (2010) argues that in addition to student learning activities and outcomes that are featured in campus internationalization strategies, the socio-cultural environment on campus should also be 
considered, as it largely influences an institution's internationalization activities. Bresciani (2009) posits that assessments should articulate what the program intends to establish concerning its services. In other words, the goals must be clear and laid out as a systematic process. There is a need for ongoing assessment processes that help leaders understand the needs of international students, develop strong teams of administrators and counselors who can work to address those needs, and secure the resources needed to help ease the transition of international students (Perez-Encinas \& Ammigan, 2016; Zhao, Kuh, \& Carini, 2005).

Hence a comprehensive assessment plan should be a university-wide responsibility and must involve all segments of the institution. An ongoing, regular assessment is critical in fulfilling the mission of the institution in all respects. Cultivating an influential culture of assessment that supports institutional effectiveness is crucial to determining if programs and services make a difference. Internationalization cannot be viewed just in terms of what institutions do, but most importantly, in conjunction with student learning as well. A wellplanned assessment effort can help shape the programs and services and aid in the betterment of the desired student outcomes.

Thus, internationalization in American institutions should include a detailed assessment and communications plan, as the literature suggests. The following actionable items outlined by scholars are crucial to ensuring that international students are provided an opportunity to voice their needs and relay their demands to student affairs administrators:

- develop an analytics-driven communication strategy;

- understand the type of information they prefer to receive, the mode of communication they prefer, and the frequency with which they prefer to receive the information;

- institute a comprehensive assessment plan; and 
- follow a "practitioner-as-researcher" model for student affairs personnel where students are surveyed to understand their preferences in student services.

\section{Institutional Leadership and Support}

Institutional support for campus internationalization is strengthened in two ways. First, a well-structured student affairs or services team is necessary to plan and execute initiatives that address the challenges faced by international students. Long wait times and unaddressed queries of international students can be minimized by hiring adequate personnel to carry out international student affairs work (Isomine, 2015). Furthermore, administrators in U.S. institutions may not be familiar with the practices and cultures of these students and, as a result, expect them to adhere to rules, deadlines, and procedures that are new and unfamiliar to them. Better services can be provided to alleviate unnecessary stress and tension for international students to the extent that administrators have access to research on the backgrounds of these students and an understanding of their educational experiences before coming to the United States as most staff and personnel are not experienced enough to understand the needs of international students (Özturgut, 2013). This can be accomplished by hiring personnel who have prior experience with other cultures or who have worked with international students (Özturgut \& Murphy, 2009). Such actions stem from leadership that encourages a comprehensive internationalization strategy (DiMaria, 2012), an organizational structure that coordinates services for international students in one highly specialized unit such as an international student office (Knight, 2011a) and an adequate budget and staff for international student services (Isomine, 2015).

Second, campus internationalization initiatives have failed in several institutions due to disconnects between departments and a lack of collaboration toward common goals. A unified 
internationalization strategy, which includes student affairs teams, is lacking in higher education institutions, a phenomenon that several researchers have deemed problematic (De Wit, 2002; Knight, 1994; Paige, 2005). Also, the lack of a campus-wide understanding of internationalization strategy compounds this problem (Childress, 2009). International strategic planning committees and student affairs departments work in silos and have a strong desire to be involved in the internationalization efforts (DiMaria, 2012). As a consequence, a distinct gap may exist between student affairs' perceptions of those needs and what international students expect from their institutions. Hudzik (2011) observes, "although sometimes ignored, these offices and programs are in strategic positions on campus to either help or hinder (by omission or commission) facilitating and supporting comprehensive internationalization" (p.21). DiMaria (2012) posits that student affairs personnel have an ardent desire to be involved in internationalization efforts but are not provided with clear opportunities to do so.

Although it is apparent that there is a widespread move towards internationalization among higher education institutions, it is interesting to find varying degrees of internationalization on campuses. These variations can be attributed to several factors, including a lack of strategic planning and a lack of administrative support for and commitment to international education (De Wit, 2002; Knight, 2004).

The American higher education system is feeling the pressure to articulate, organize, advocate, and lead the way in internationalization. Establishing the lack of proper strategic planning and the non-inclusion of student affairs in campus internationalization should spur further research on the extent to which U.S. colleges and universities do or do not sufficiently plan for international students. Among the organizational deficits, internationalization activities 
are confined to a rather narrow definition of what the international students may need as opposed to what they need.

Specifically, the following recommendations, if followed by American higher education institutions, could help build a strong community that is culturally responsive to international students and enable them to better accommodate themselves in their new environment:

- develop a campus-wide understanding of internationalization strategy;

- establish strategy planning teams that involve student affairs professionals and employ collaborative planning approaches;

- establish one highly specialized unit such as an international student office;

- assure that there are an adequate number of staff members for international student services; and

- provide an adequate budget for international student services

\section{Summary}

This chapter includes a review of the literature, which frames the study and the survey instrument. The chapter began with a review of global student mobility, the role of the United States amidst these trends, and implications associated with each. Additionally, the chapter examined the key conversations in the literature on campus internationalization, beginning with efforts to define the concept. The literature on international student challenges was examined in detail in addition to the literature on international student services across four themes: Student engagement and services, assessment and communication, intercultural and global competence, and institutional leadership and support. Recommendations, drawn from the literature, for addressing the challenges faced by international students were noted under each theme. These recommendations were used in the development of the questionnaire items employed in this 
study. The next chapter examines the development of the questionnaire, as well as the processes used in its administration. 


\section{CHAPTER III: RESEARCH METHODS}

Offices of international students and services in American colleges and universities occasionally gauge the satisfaction of international students with campus services using instruments such as the International Student Barometer and the National Survey of Student Engagement (e.g., Korobova \& Starobin, 2015; Nilsson \& Ripmeester, 2016). However, none of these survey instruments has been designed to systematically document the services that colleges and universities actually provide international students, nor have prior studies assessed those services against recommendations in the literature concerning how colleges and universities might best help these students. Therefore, this study examines the perceptions of international student services personnel concerning the services that colleges provide and the services that, according to the literature, should be provided. In addition, the study also examines the gap (to the extent there is one) between these perceptions. Drawing on a survey of Midwestern members of NAFSA, the study is guided by the following research questions:

1. What services do student services personnel perceive that their institutions are providing for international students?

2. What services do student services personnel perceive that their institutions should be providing for international students?

3. Is there a gap between what services student services personnel perceive that their institutions are providing and what services should be provided?

\section{Data Inquiry Strategy}

The study utilized a quantitative research design employing an internet survey to elicit primarily close-ended responses. According to Creswell (2009), quantitative research is the best approach for understanding the relationship between variables. Survey research is often used to 
quantify attitudes, perceptions, and opinions of a subset of a population, sometimes assessing the probability that responses from that subset are representative of the population as a whole (though this exploratory study does not aim for generalizable findings). In addition, internet surveys are less expensive and more convenient modes of collecting data while maintaining anonymity.

\section{Designing the Instrument}

The researcher analyzed several journal articles and ran an ERIC database search using several descriptors (e.g., student services, international/foreign students, campus services) to identify research that may contain instruments. The Mental Measurements Yearbook was also checked for instruments analyzing campus services for international students. Having found no instruments that address the research questions, or that serve the objectives of this study, the researcher decided to develop an instrument of her own.

Three steps were employed in developing an initial survey instrument. The first step was the development of a draft questionnaire on the basis of the literature examined in Chapter Two. This draft questionnaire (Appendix A) was designed to answer the research questions outlined earlier and consisted of two sections. The first section included 31 statements covering the campus services recommended in the literature. For each item, respondents were asked to rank their level of agreement concerning (a) the extent to which the statement reflects what their institutions actually do for international students and (b) the extent to which the statement reflects what their institutions should do for international students. This allowed the researcher to get a sense of how those responsible for the well-being of international students perceive that their institutions are doing what needs to be done. Items in the survey were organized according to the conceptual framework, reflecting four key areas of campus internationalization: student 
engagement and experience, intercultural and global competence, assessment and communications planning, and institutional leadership and support. These four categories are listed in Table 1, below, along with the questionnaire items associated with each.

The second section of this initial questionnaire collected demographic and background data on the respondents, as well as questions related to the institutions they represent, including the challenges faced by the institution in recruiting international students, the types of services those institutions provide international students, and the offices that oversee those services. The last three items in the second section were open-ended questions eliciting information on the current services offered for international students and the challenges faced in offering comprehensive international student services. This section provided additional information on the barriers to implementing comprehensive international campus services.

The second step in designing the questionnaire involved a qualitative assessment involving five selected NAFSA members who work at university offices devoted to international students. Purposive sampling and snowball sampling were used to identify a group of individuals who are knowledgeable about international student services. The researcher chose individuals outside the Midwest. The researcher used her own judgement to choose individuals who are NAFSA members and who head the offices devoted to international students at public and private universities. After choosing one Director of international and Student services at a public university in Kentucky, the researcher used references from this individual to contact others. In this way, five individuals from private and public universities in California (2), Kentucky (2), and Ohio (1) were selected to provide qualitative feedback on designing the survey. 
Table 1

Items in the Initial Draft Questionnaire that were Associated with Each of the Four Parts of the Conceptual Framework

Category/

domain

Corresponding survey items

Student

engagement and

services
- My institution provides/should provide career services that help international students find on-campus, parttime jobs

- My institution provides/should provide career services that help international students by helping them find internships or other employment opportunities that relate to coursework.

- My institution provides/should provide career services that help international students find work or internships after graduation.

- My institution offers/should offer workshops to help international students overcome their reluctance to access mental health services.

- Counselors and advisors in my institution reach out / should reach out to international students informally on campus as a way of overcoming any reluctance they may have to seek out help for personal concerns or problems they are encountering.

- My institution provides /should provide workshops/programs to help international students understand U.S. government regulations on maintaining student visas.

- My institution provides /should provide opportunities for international students to develop professional connections with faculty members outside of class.

- My institution provides /should opportunities for international students to interact with and learn from students of other cultures through activities on and off campus.

- My institution provides/should provide opportunities for international students to participate in learning and development activities offered through student clubs, organization, and activities.

- My institution develops/should develop religiously affiliated centers for international students, recognizing that their cultural needs are different from those of domestic students

- My institution provides /should provide academic writing support for international students that emphasizes rich content rather than mere grammatical correctness.

(Table Continues) 
Category/

domain

- My institution provides/should provide in-depth academic orientations that help international students understand how the expectations made of them in American classrooms may differ from what they experienced in their home countries.

- My institution provides / should provide transition support programs for international students immediately after their arrival on campus

- My institution provides/should provide extended, semester-long orientations that support international students during their first months at the institution.

- My institution provides/ should provide first-year experience programs lasting a whole year to support international students.

- My institution provides/should provide pre-engagement (i.e., pre-arrival) support programs that provide (international students with information about academics, as well as social and cultural differences, even before they leave their home countries.

- My institution provides/ should provide faculty members with training on how American classrooms and instructional techniques differ from what international students have been used to in their home countries.

Intercultural and global competence
- My institution provides/should provide student affairs staff with training that will enhance the intercultural competence needed to work with international students.

- My institution builds/ should build intercultural competence among its faculty through opportunities for international exchange.

- My institution includes/ should include intercultural competence development in annual staff appraisals.

- My institution offers/should offer continuing education programs that help staff build intercultural competence

- Courses throughout the curriculum build/should build the intercultural competencies of both domestic and international students.

- My institution provides/ should provide academic advisors with opportunities for professional development abroad.

- My institution provides/ should provide certificate courses on various aspects of intercultural competence (e.g., communication, empathy, cultural considerations etc.) for international student services (ISS) staff

(Table Continues) 
Category/

domain

Corresponding survey items

Assessment and

communication

- My institution surveys/Should Survey international students on a regular basis to understand their preferences for receiving information (e.g., e-mail, face-to-face, social media, etc.)

- My institution surveys/ Should Survey international students on a regular basis to understand how frequently they would prefer to receive information from their institutions.

- My institution surveys/should survey international students on a regular basis to understand the types of information that will be most helpful to them.

- My institution assesses/should assess the extent to which international students are satisfied with campus support services.

Institutional

Leadership and

- My institution has an office that coordinates support services for international students across the campus.

- My institution adequately staffs/should adequately staff student affairs offices so that international students do not have to wait too long to get their queries addressed.

- My institution hires/should hire personnel who have previous experience working with international students. 
An e-mail was sent to these individuals requesting their feedback on the clarity of the questionnaire items; a follow-up phone conversation was conducted with each participant to discuss his or her feedback. The participants recommended clarifying the questions by changing some words, rearranging the questions, and combining some questions for better clarity. Also, the respondents recommended moving questions concerning demographics to the beginning of the survey. The questionnaire was modified accordingly and was reduced from 31 paired statements to 27 (Appendix B).

Step 3 involved pre-testing the instrument, examining its reliability, employing factor analysis to determine the instrument's alignment with the study's conceptual framework, and determining if the length of time required to complete the survey was acceptable to respondents. Pretesting the questionnaire was conducted by sending the questionnaire to 70 international student services professionals who are NAFSA members. These individuals were randomly selected from those employed in international student services offices in four-year public and private institutions outside of the Midwest. E-mail messages were sent to these professionals, requesting their participation in the pilot survey and providing them with the survey web address and instructions necessary to complete the survey. In addition to answering the survey questions, the pilot participants were asked to provide feedback on the time taken to complete the survey and note any computer glitches they may have encountered while completing the survey.

The pilot survey was completed by 43 participants within two weeks of this email communication. After receiving the survey results, the researcher analyzed the feedback provided by the respondents, which focused on five issues:

a. The survey was too long. The time taken to complete the survey exceeded 20 minutes, resulting in several missing responses. 
b. The placement of the items in the survey (i.e., 27 "as is" statements followed by 27 "should be" statements) made it difficult for respondents to complete the survey. It became clear that the questionnaire should be comprised of paired statements (i.e., each "as is" statement and its corresponding "should be" statement placed side-by side).

c. Part 2 of the survey took too long to complete, and most respondents skipped the questions.

d. Statements in the questionnaire were often deemed too lengthy, causing respondents to lose interest.

e. Finally, the survey should be available on a mobile-friendly platform with the twopart statements side by side.

The researcher also employed the Kaiser-Meyer-Olkin Measure of Sampling Adequacy and factor analysis. A Cronbach alpha coefficient of $0.838(n=42)$ suggested that the instrument scales are consistent and reliable. However, because there were several missing values, the factor analysis did not yield any meaningful output. Hence the mean differences for paired statements (i.e., the mean difference in responses to each "as is" statement and its corresponding "should be" statement) were calculated. Very low mean differences indicate that the items represent common practices followed by institutions. Accordingly, eight paired statements with mean differences between 0 and 0.50 were eliminated:

- My institution should survey international students on a regular basis to understand the types of information or communication that will be most helpful to them.

- My institution provides/should provide workshops or programs to help international students understand U.S. government regulations on maintaining student visas 
- My institution provides/should provide opportunities for international students to interact with and learn from students of other cultures through activities on and off campus.

- My institution provides /should provide opportunities for international students to further their learning and development through participation in student clubs, organizations, and other campus activities.

- My institution provides/should provide in-depth on-campus academic orientations that help international students understand how American classrooms may differ from what they experienced in their home countries.

- My institution builds intercultural competence among its faculty through opportunities for international exchange

- My institution provides academic advisors with opportunities for professional development abroad that help develop intercultural competence

- My institution should provide certificate courses on various aspects of intercultural competence (e.g., communication, empathy, cultural considerations, etc.) for international student services (ISS) staff.

Next, the following three statements were combined because they were essentially redundant: "My institution should help international students find on-campus part-time assistantships"; "My institution helps/should help international students find internships or training opportunities that relate to coursework"; "My institution provides/should career services that help international students find work internships after graduation." The new, combined statement was, "My institution helps international students find on-campus, part-time assistantships and student work." 
Then, the researcher used the literature on intercultural competence to add the following item to the survey: "My institution intervenes in an appropriate manner when staff engage in behaviors that show cultural insensitivity, racial biases, or prejudice.” The literature emphasizes the importance of incorporating cultural competencies in practice and holding institutional leaders accountable for this (Deardoff, 2004; Goode, 2002). This question replaced three items on intercultural competence that were eliminated as a way of shortening the survey: "My institution builds intercultural competence among its faculty through opportunities for international exchange"; "My institution provides academic advisors with opportunities for professional development abroad that help develop intercultural competence"; and "My institution provides certificate courses on various aspects of intercultural competence (e.g., communication, empathy, cultural considerations, etc.) for international student services (ISS) staff."

Next, the background questions in the pilot survey were deleted, also as a way of reducing the length of the survey. Questions on the type of institution and the total number of international students enrolled, were retained, while two more questions were added: "My institution has an internationalization strategic plan" and "My institution's budget includes monies that are specifically targeted for international student services." Also, open-ended questions were eliminated, as were questions eliciting demographic data on the respondents themselves. Thus, the final survey included two background questions and 21 paired statements describing institutional actions, programs, or services that are designed to help international students (Appendix C). Each pair of statements asked respondents to indicate their level of agreement that the action, program, or service specified in the statement reflects (a) actual practice at their institutions and (b) practice as it should be at their institutions. After obtaining 
approvals from the dissertation committee and Illinois State University's IRB, the questionnaire was administered to a sample of international student services professionals in both public and private four-year institutions in the Midwest; pilot participants were not included in the study sample. Appendices D and E provides copies of informed consent forms.

\section{Study Participants and Procedures}

The population from which the sample for this study was drawn consists of international student affairs professionals employed at four-year public and private institutions within the 12 states that comprise the Midwest Higher Education Compact (MEHC): Illinois, Indiana, Iowa, Kansas, Michigan, Minnesota, Missouri, Nebraska, North Dakota, Ohio, South Dakota and Wisconsin. The participants were selected from the NAFSA member directory. NAFSA is the largest association of professionals committed to international higher education. Its members seek to integrate international perspectives in every aspect of higher education and include students and academic researchers, as well as frontline professionals such as presidents, provosts, and deans. This nonprofit organization has more than 10,000 members from over 2000 institutions in the United States.

As a first step in identifying respondents for this study, the researcher identified the members listed in the directory who (a) worked at a public or private university in one of the MHEC states ( $\mathrm{n}=1940)$ and $(\mathrm{b})$ belonged to NAFSA's Leading Internationalization Network $(\mathrm{n}=$ 565). This "network provides resources and guidance for international education leaders worldwide on a full range of topics, from management and leadership to partnerships to assessment and evaluation" (NAFSA, 2019a, para. 2) The researcher then reviewed organizational charts of student affairs divisions located at each institution in the Midwest to identify those individuals in this subgroup who engage in student affairs work with international 
students (as opposed, for example, to working as a faculty member or in some other aspect of university operations). This led to a total of 272 potential respondents comprised of managers, administrators, and those in leadership positions in student services offices devoted to academic services, career services, counseling services, health services, legal services, residence services, and recreation services for international students.

A personal e-mail was sent to all potential participants in September 2019, requesting their participation in the study and providing them with a link to a Qualtrics site where they could respond to the questionnaire. An e-mail analytics feature allowed the researcher to track responses and send reminder e-mails with personalized messages. After two weeks, 65 responses (23.3\% response rate) had been received. A reminder e-mail was then sent to all the participants, increasing the total number of responses to 99 (35.6\% response rate). The researcher then sent a personal letter to the entire sample of 272 individuals. This personalized touch increased the number of responses to $158(56.8 \%)$ within two weeks of the mailing. A final reminder e-mail was sent to the potential respondents on November 4, 2019. Finally, the survey was closed on November 15, 2019, after a total of 207 responses had been received, yielding a response rate of $74.5 \%$. Of the 207 responses, only 147 had complete responses and so the 147 responses analyzed.

\section{Data Analysis}

Survey responses were analyzed with SPSS statistical software (version 26) to answer the study's research questions. A factor analysis was first conducted to identify those survey items that can be grouped into factors, reducing the number of paired statements that could be subject to analysis. Response rates and mean responses were calculated for the statements in those factors. Inferential statistics ( $t$-tests) were then used to compare the respondent perceptions of the 
extent to which statements reflect actual practice and the extent to which the respondents perceived that they reflect practice as it should be. The next chapter details the results of this analysis. 


\section{CHAPTER IV: RESULTS}

This study examines the perceptions of international student services personnel on the services that colleges provide and the services that, according to the literature, should be provided. In addition, the study also examines the gap (to the extent there is one) between these perceptions. The data were collected using an online survey. This chapter details survey results, beginning with descriptive statistics on the types of institutions at which the respondents were employed as well as on the number of international students enrolled at those institutions. The results of a factor analysis undertaken to meaningfully group items and reduce the number subject to analysis are then presented. Finally, descriptive and inferential statistics are employed to answer the study's three research questions:

1. What services do student services personnel perceive that their institutions are providing for international students?

2. What services do student services personnel perceive that their institutions should be providing for international students?

3. Is there a gap between what services student services personnel perceive that their institutions are providing and what services should be provided?

\section{Participants and Their Institutions}

The participants in this study are employed at public and private universities in the 12 states that comprise the Midwest Higher Education Compact, are members of NAFSA, and work in offices that provide institutional services for international students. As data in Table 2 indicate, most (61.2\%) of the 147 respondents are employed at public institutions; $38.2 \%$ are employed at private institutions, and one respondent did not indicate the type of institution at which he or she was employed. 
Table 2

Distribution of Respondents, by Institutional Type

\begin{tabular}{lcr}
\hline Institutional type & $\mathrm{N}$ & \multicolumn{2}{c}{61.2} \\
\hline Four-year public college or university & 90 & 36.1 \\
Four-year private, non-profit college or university & 53 & 2.0 \\
Four-year private, for-profit college or university & 3 & .7 \\
Unknown & 1 & 100.0 \\
Total & 147 & \\
\hline
\end{tabular}

Midwestern universities and colleges enroll a high number of international students. As data in Table 3 indicate, about $35 \%$ of the universities at which the respondents are employed enroll 100-500 international students while another 35\% enroll more than 1,000 students. In total, $50 \%$ of the institutions enroll more than 500 international students. indicating a strong need for robust student services geared toward their needs. The proportion is even higher (70\%) when looking at public institutions only.

Table 3

Number of International Students at the Respondent's Institutions, by Type of Institution

\begin{tabular}{|c|c|c|c|c|c|c|c|c|}
\hline \multirow{2}{*}{$\begin{array}{c}\text { Number of } \\
\text { international } \\
\text { students }\end{array}$} & \multicolumn{2}{|c|}{ Public } & \multicolumn{2}{|c|}{$\begin{array}{l}\text { Private, } \\
\text { nonprofit }\end{array}$} & \multicolumn{2}{|c|}{$\begin{array}{c}\text { For-profit } \\
\text { private }\end{array}$} & \multicolumn{2}{|c|}{ All institutions } \\
\hline & $n$ & $\%$ & $n$ & $\%$ & $n$ & $\%$ & $n$ & $\%$ \\
\hline $1-50$ & 0 & 0.0 & 6 & 11.3 & 1 & 33.3 & 1 & 4.8 \\
\hline $51-100$ & 5 & 5.6 & 10 & 18.9 & 0 & 0.0 & 15 & 10.3 \\
\hline $101-250$ & 5 & 5.6 & 16 & 30.2 & 0 & 0.0 & $\begin{array}{r}21 \\
\text { (Table co }\end{array}$ & $\begin{array}{r}14.4 \\
\text { nued) }\end{array}$ \\
\hline
\end{tabular}




\begin{tabular}{|c|c|c|c|c|c|c|c|c|}
\hline \multirow{2}{*}{$\begin{array}{l}\text { Number of } \\
\text { international } \\
\text { students }\end{array}$} & \multicolumn{2}{|c|}{ Public } & \multicolumn{2}{|c|}{$\begin{array}{r}\text { Private, } \\
\text { nonprofit }\end{array}$} & \multicolumn{2}{|c|}{$\begin{array}{c}\text { For-profit } \\
\text { private }\end{array}$} & \multicolumn{2}{|c|}{ All institutions } \\
\hline & $n$ & $\%$ & $n$ & $\%$ & $n$ & $\%$ & $n$ & $\%$ \\
\hline $251-499$ & 18 & 20.0 & 12 & 22.6 & 1 & 33.3 & 31 & 21.2 \\
\hline $500-750$ & 13 & 14.4 & 3 & 5.7 & 0 & 0.0 & 16 & 11.0 \\
\hline $751-999$ & 5 & 5.6 & 0 & 0.0 & 0 & 0.0 & 5 & 3.4 \\
\hline $1000-2000$ & 16 & 17.8 & 0 & 0.0 & 1 & 33.3 & 17 & 11.6 \\
\hline $2001-4999$ & 19 & 21.1 & 5 & 9.4 & 0 & 0.0 & 24 & 16.4 \\
\hline$>5000$ & 9 & 10.0 & 1 & 1.9 & 0 & 0.0 & 10 & 6.8 \\
\hline Total & 90 & 100.0 & 53 & 100.0 & 3 & 100.0 & 146 & 100.0 \\
\hline
\end{tabular}

\section{Factor Analysis}

The participants in this research were presented 21 paired statements on various campus services that the literature suggests are needed by international students. They were asked to rate their level of agreement that (a) the statement reflects current practice at their institutions and (b) the statement reflects what should be done at their institutions. Following the principle of parsimony, exploratory actor analysis was conducted as a data reduction technique in SPSS. Before proceeding to the factor extraction, the Kaiser-Meyer-Olkin (KMO) measure of sampling adequacy was performed to determine if there is a linear relationship between the variables and if the factor extraction can be performed. The KMO value for the items were .798 indicating that the sample is adequate. Bartletts' test of sphericity, which assesses the correlation between the variables, was undertaken as well; results the assumption of factorability $(\chi 2(42)=673.382, p<$ .001$.

Once the factorability was established, the researcher proceeded to perform factor extraction to identify the categories and to determine the extent to which those categories match the four dimensions of the conceptual framework adapted from Briggs and Ammigan (2017). 
The principal component matrix is considered most appropriate for factor extraction (Fabrigar et al., 1999) and was used in this instance. In order to determine the factors, the researcher used factor loadings above .33 to ensure that at least $30 \%$ of the items are explained and related. The factors were ranked on their mean scores. Two of the 21 paired statements did not meet the desired correlation of .33 or higher and were thus removed as they were not correlated with the other items: "My institution writes/should write notices and communications to international students in their native languages," and "My institution understands/should understand that it is necessary to use alternatives formats (e.g., face-to-face, social media, etc.) in addition to written formats when communicating with international students." After removing the two questions, the factor reduction resulted in three components that correspond to three of the dimensions of the conceptual framework adapted from Briggs and Ammigan: (a) student engagement and services, which includes seven paired statements; (b) intercultural and global competence (IGC), which includes five paired statements, and (c) institutional leadership and support (ILS), which includes 7 paired statements. Table 4 lists statements arranged by the specific categories they fall into. Table 4

Study Variables Grouped as per the Categories

\begin{tabular}{lll}
\hline Category & \multicolumn{1}{c}{ Variable } & $\begin{array}{l}\text { Number of participants } \\
\text { responding to each item }\end{array}$ \\
\hline $\begin{array}{l}\text { Student } \\
\text { engagement } \\
\text { and services }\end{array}$ & $\begin{array}{l}\text { My institution surveys/should survey } \\
\text { international students to understand how } \\
\text { frequently they would prefer to receive } \\
\text { information from the institution }\end{array}$ & \\
\hline
\end{tabular}

(Table Continues) 


\begin{tabular}{|c|c|c|}
\hline \multirow[t]{2}{*}{ Category } & \multirow[t]{2}{*}{ Variable } & $\begin{array}{l}\text { Number of participants } \\
\text { responding to each item }\end{array}$ \\
\hline & & Should be \\
\hline
\end{tabular}

My institution assesses/should assess the extent to which international students are satisfied with campus support services.

My institution provides/should provide preengagement (i.e., pre-arrival information for international students on academics, social and cultural differences in the U.S., even before they leave their home countries

My institution provides/should provide extended, semester-long orientations for international students during their first months at the institution.

My institution provides/ should provide writing support for international students that goes beyond grammar and emphasize disciplinary content and context.

My institution provides/ should provide opportunities for international students to interact with faculty members outside of class.

My institution helps/should help international students find part-time assistantships or employment on campus.

Intercultural My institution provides/ should provide faculty and global members with training on how American competency (IGC) classrooms and instructional techniques differ from what international students have been used to in their home countries 


\begin{tabular}{|c|c|c|}
\hline \multirow[t]{2}{*}{ Category } & Variable & $\begin{array}{l}\text { Number of participants } \\
\text { responding to each item }\end{array}$ \\
\hline & & Should be \\
\hline
\end{tabular}

My institution provides/ should provide training in intercultural competence for faculty and staff who work with international students.

My institution includes intercultural competence as a criterion in performance appraisals of faculty and staff who work with international students.

My institution assures/should assure that courses throughout the curriculum build the intercultural competencies of both domestic and international students.

My institution intervenes/should intervene in an appropriate manner when faculty and staff engage in behaviors that show cultural insensitivity, racial biases, or prejudice

Institutional My institution helps/should help international leadership and support (ILS) students overcome any reluctance they might have to access counseling services (e.g., mental health services.

My institution develops/should develop religiously affiliated centers for international students, recognizing that their cultural needs may be different from those of domestic students

My institution has/should have a strategic plan for international student services or includes international student services in the strategic plan of student affairs

My institution's budget includes/should include monies that are specifically targeted for international student services. 


\begin{tabular}{llll}
\hline Category & \multicolumn{1}{c}{ Variable } & \multicolumn{1}{c}{$\begin{array}{c}\text { Number of participants } \\
\text { responding to each item }\end{array}$} \\
& As is & Should be \\
\hline $\begin{array}{l}\text { My institution has/should have an office that } \\
\text { coordinates support services for international } \\
\text { students }\end{array}$ & 146 & 135 \\
$\begin{array}{l}\text { My institution adequately staffs/should } \\
\text { adequately staff international student offices or } \\
\text { international student affairs offices. }\end{array}$ & 147 & 135 \\
$\begin{array}{l}\text { My institution hires/should hire personnel in } \\
\text { international student offices or international } \\
\text { student affairs units who have previous } \\
\text { experience working with international students. }\end{array}$ & 147 & 139 \\
\hline
\end{tabular}

\section{Research Question 1: What Services Do Respondents Perceive that Their Institutions are Providing for International Students?}

The first research question aims to understand the views of the respondents towards the current state of international student services. As described in the previous chapter, the internet survey posed statements regarding campus services for international students. The rating scale used in the survey was from 1 to 5 , with 1 indicating "don't know," 2 indicating "strongly disagree," 3 indicating "disagree," 4 indicating "agree," and 5 indicating "strongly agree." The following paragraphs detail responses to items in each of the three categories that emerged from the factor analysis.

\section{Student Engagement and Services (SES)}

A majority of respondents $(60-70 \%)$ agreed or strongly agreed that most of the statements in the SES category reflect actual practice at their institutions. Those statements, in order of 
mean ratings relate to prearrival orientation, help in finding part-time assistantships or employment on campus, writing support that goes beyond grammar and emphasizes disciplinary content and context, the provision of opportunities to interact with faculty members outside of class, and the assessment of student satisfaction with campus services. There were two exceptions, however. Most respondents ( $60 \%-65 \%)$ disagreed or disagreed strongly that their institutions survey international students to understand how frequently they would prefer to receive information, and that their institutions provide extended, semester-long orientations for international students during their first months at the institution.

Table 5

Responses to Actual Practice for Student Engagement and Services Component

\begin{tabular}{ccccccc}
\hline & Don't & Strongly & Disagree & Agree & Strongly \\
know & disagree & Dgree & $(\%)$ & $(\%)$ & $(\%)$ & \\
\hline
\end{tabular}

My institution surveys international students to understand how frequently they would prefer to receive $\begin{array}{llllll}15.6 & 25.5 & 41.1 & 14.9 & 2.8 & 2.64\end{array}$ information from the institution

My institution assesses the extent to which international students are satisfied with campus support services.

$\begin{array}{llllll}1.4 & 13.6 & 23.8 & 47.6 & 13.6 & 3.59\end{array}$

(Table Continues) 


\begin{tabular}{ccccccc}
\hline \multirow{3}{*}{ Survey Questions } & $\begin{array}{c}\text { Don't } \\
\text { know } \\
(\%)\end{array}$ & $\begin{array}{c}\text { Strongly } \\
\text { disagree } \\
(\%)\end{array}$ & $\begin{array}{c}\text { Disagree } \\
(\%)\end{array}$ & $\begin{array}{c}\text { Agree } \\
(\%)\end{array}$ & $\begin{array}{c}\text { Strongly } \\
\text { agree } \\
(\%)\end{array}$ & $M$ \\
\hline
\end{tabular}

My institution provides preengagement (i.e., pre-arrival information for international students on academics, social and cultural differences in the U.S., even before they leave their home countries

$\begin{array}{llllll}2.0 & 2.0 & 10.2 & 40.8 & 44.9 & 4.24\end{array}$

My institution provides extended, semester-long orientations for international students during their first months at the institution.

$\begin{array}{llllll}2.1 & 19.3 & 44.1 & 21.4 & 13.1 & 3.24\end{array}$

My institution provides writing support for international students that goes beyond grammar and emphasize disciplinary content and context.

$\begin{array}{llllll}4.8 & 6.1 & 10.2 & 46.9 & 32.0 & 3.95\end{array}$

My institution provides opportunities for international students to interact with faculty members outside of class.

$\begin{array}{llllll}9.0 & 2.1 & 17.2 & 46.2 & 25.5 & 3.77\end{array}$

My institution helps international students find part-time assistantships or employment on campus.

$\begin{array}{llllll}0.0 & 3.4 & 17.0 & 53.1 & 26.5 & 4.03\end{array}$

\section{Intercultural and Global Competency (IGC)}

Among the statements in the intercultural and global competency category (Table 6), none yielded a mean score above 4 , indicating that this aspect of work with international students may need additional attention. On average, $60 \%$ of the respondents disagree or strongly disagree that the practices reflected in these statements reflect actual practice at their institutions. When 
asked if their institutions include intercultural competence as a criterion in performance appraisals of faculty and staff who work with international students, $31.0 \%$ disagreed and $27.5 \%$ strongly disagreed. Furthermore, $29.7 \%$ strongly disagreed and $18.6 \%$ disagreed that their institutions provide faculty members with training on how American classrooms and instructional techniques differ from what international students have been used to in their home countries. Similarly, $26.0 \%$ disagreed and $19.9 \%$ strongly disagreed that their institutions train faculty and staff on intercultural competencies. In contrast, however, $47.3 \%$ agreed and $21.2 \%$ strongly agreed that their institutions intervene if faculty and staff engage in behaviors that show cultural insensitivity, racial biases, or prejudice. In terms of curriculum, responses were mixed; $38.3 \%$ of respondents disagreed or disagreed strongly that their institutions assure that courses throughout the curriculum build the intercultural competencies of both domestic and international students, while $44.6 \%$ agreed or disagreed strongly.

In short, responses in this category suggest that more attention to intercultural or global competency is warranted. It is interesting to note, however, that many respondents were unsure of what their institutions may be doing in this area. For example, $30.3 \%$ of the respondents didn't know if intercultural competence factored into the performance appraisals of faculty and staff. In addition, $17 \%$ didn't know if courses at their institutions strengthen the intercultural competencies of students. 
Table 6

Responses to Actual Practice for Intercultural and Global Competency Component

\begin{tabular}{ccccccc}
\hline Survey Questions & $\begin{array}{c}\text { Don't know } \\
(\%)\end{array}$ & $\begin{array}{c}\text { Strongly } \\
\text { disagree } \\
(\%)\end{array}$ & $\begin{array}{c}\text { Disagree } \\
(\%)\end{array}$ & $\begin{array}{c}\text { Agree } \\
(\%)\end{array}$ & $\begin{array}{c}\text { Strongly } \\
\text { agree } \\
(\%)\end{array}$ & $M$ \\
\hline
\end{tabular}

My institution provides faculty members with training on how American classrooms and instructional techniques differ from what international students have been used to in their home countries.

$\begin{array}{llllll}8.3 & 18.6 & 29.7 & 32.4 & 11.0 & 3.19\end{array}$

My institution provides training in intercultural competence for faculty and staff who work with international students.

My institution includes intercultural competence as a criterion in performance appraisals of faculty and staff who work with international students.

My institution assures that courses throughout the curriculum build the intercultural competencies of both domestic and international students.

My institution intervenes in an appropriate manner when faculty and staff engage in behaviors that show cultural insensitivity, racial biases, or prejudice 


\section{Institutional Leadership and Support (ILS)}

Respondents appeared more certain in their ratings of statements in the institutional leadership and support category (Table 7). Almost all (97\%) agreed that their institutions have an office created exclusively to cater to the international student population, and $85 \%$ agreed or strongly agreed that these offices hire staff who have previous experience working with international students. In addition, the $58.6 \%$ of the respondents agreed and $25.5 \%$ strongly agreed that their institutions help international students overcome any reluctance they might have to access counseling services (including mental health services). In terms of available monies, $44.5 \%$ agreed and $33.6 \%$ strongly agree that institutional budgets include funds that are targeted specifically toward international student services. However, 52.4\% disagreed or disagreed strongly that their institutions adequately staff international student offices. In addition, $21.2 \%$ disagreed and $15.1 \%$ strongly disagreed that the strategic plans developed by their institutions include plans for services that support international students. In terms of religiously affiliated centers for international students, $43 \%$ of the respondents disagreed or disagreed strongly that their institutions attend to this, while $50 \%$ agreed or strongly agreed.

In short, both public and private institutions have a dedicated office for international students. However, institutional leadership and support should stem from a strategic plan and unfortunately, most institutions do not have one. Although most respondents agreed that institutional budgets include monies that support services for international students, just over half (52.4\%) disagreed or disagreed strongly that their institutions adequately staffed international student offices or international student affairs offices. 
Table 7

Responses to Actual Practice for Institutional Leadership and Support Component

\begin{tabular}{cccccc}
\hline Survey Questions & $\begin{array}{c}\text { Don't know } \\
(\%)\end{array}$ & $\begin{array}{c}\text { Strongly } \\
\text { disagree } \\
(\%)\end{array}$ & $\begin{array}{c}\text { Disagree } \\
(\%)\end{array}$ & $\begin{array}{c}\text { Agree } \\
(\%)\end{array}$ & $\begin{array}{c}\text { Strongly } \\
\text { agree } \\
(\%)\end{array}$
\end{tabular}

My institution has a strategic plan for international student services or includes international student services in the strategic plan of student affairs

My institution's budget includes monies that are specifically targeted for international student services.

2.1

My institution has an office that coordinates support services for international students

0.0

0.0

2.7

28.1

$69.2 \quad 4.66$

My institution adequately staffs international student offices or international

17.0

35.4

28.6

18.4

student affairs offices.

My institution hires personnel in international student offices or international student affairs units who have previous experience working with

4.1

7.5

36.7

49.0

4.25 international students.

My institution helps international students overcome any reluctance they might have to access counseling services (e.g., mental health services.

11.0

58.6 25.5 


\begin{tabular}{ccccccc}
\hline Survey Questions & $\begin{array}{c}\text { Don't know } \\
(\%)\end{array}$ & $\begin{array}{c}\text { Strongly } \\
\text { disagree } \\
(\%)\end{array}$ & $\begin{array}{c}\text { Disagree } \\
(\%)\end{array}$ & $\begin{array}{c}\text { Agree } \\
(\%)\end{array}$ & $\begin{array}{c}\text { Strongly } \\
\text { agree } \\
(\%)\end{array}$ & $M$ \\
\hline
\end{tabular}

My institution develops religiously affiliated centers for international students, recognizing that their cultural needs may be different from those of domestic students 7.0 14.1 28.9 36.6 13.4

Several respondents have chosen 'Don't Know' response for some of the statements, which was assigned a value of 1 . Nonetheless, this is a finding in itself and is discussed later in the chapter.

\section{Research Question 2: What Services Do Student Services Personnel Perceive That Their Institutions Should Be Providing for International Students?}

The second research question aims at describing participants' views on what their institutions should do in terms of campus services for international students. Almost all the statements under these categories had a mean value of greater than 4 , strongly indicating a renewed interest among the participants in implementing these practices at their institutions. Almost all services were considered essential by an average of $90 \%$ of the respondents.

Table 8 provides a summary of responses for all paired statements in the three categoriesstudent engagement and services, intercultural and global competency, and institutional leadership and support. It is no surprise that the respondents felt that all the listed practices were important for international students. The majority of the respondents, over $90 \%$, strongly felt the need to train faculty on classroom needs of international students. In addition, the survey demonstrated the need not only to train staff, but also to hold them accountable by including intercultural competence in performance appraisals and intervening when faculty and staff 
engage in behaviors that show cultural insensitivity, racial biases, or prejudice. Furthermore, respondents strongly supported student orientation programs as well as the provision of writing support. This is consistent with the literature on international student support services. Similarly, responses indicate that writing support and career services are commonly offered at the respondents' institutions and that those participating in the survey strongly felt that these are services that should be provided. However, around $14 \%$ of the respondents disagreed that their institutions should develop religiously affiliated centers for international students. 
Table 8

Responses to The Ideal Situation, by Domain (SES, IGC and ILS)

\begin{tabular}{|c|c|c|c|c|c|c|}
\hline & Don't know & $\begin{array}{l}\text { Strongly } \\
\text { disagree }\end{array}$ & Disagree & Agree & Strongly agree & Mean \\
\hline Survey Questions & $\%$ & $\%$ & $\%$ & $\%$ & $\%$ & \\
\hline
\end{tabular}

Student Engagement and Services (SES)

My institution surveys international students to understand how frequently they would prefer to receive $\begin{array}{lll}6 & 4.2 & 3\end{array}$

2.119

83

$58.0 \quad 32$

My institution assesses the extent to which international students are $0 \quad 0$

0.0

0

1

$0.7 \quad 58$

My institution provides preengagement (i.e., pre-arrival information for international students on academics, social and cultural differences in the U.S., even before they leave their home countries

$\begin{array}{ll}0 & 0.0\end{array}$

0

0.0

32

$2.2 \quad 34 \quad 24.6 \quad 101$

$73.2 \quad 4.71$

(Table Continues) 


\begin{tabular}{|c|c|c|c|c|c|c|c|c|c|c|c|}
\hline \multirow[b]{2}{*}{ Survey Questions } & \multicolumn{2}{|c|}{ Don't know } & \multicolumn{2}{|c|}{$\begin{array}{l}\text { Strongly } \\
\text { disagree }\end{array}$} & \multicolumn{2}{|c|}{ Disagree } & \multicolumn{2}{|c|}{ Agree } & \multicolumn{2}{|c|}{ Strongly agree } & \multirow[t]{2}{*}{ Mean } \\
\hline & $n$ & $\%$ & $n$ & $\%$ & $n$ & $\%$ & $n$ & $\%$ & $n$ & $\%$ & \\
\hline $\begin{array}{l}\text { My institution provides extended, } \\
\text { semester-long orientations for } \\
\text { international students during their first } \\
\text { months at the institution. }\end{array}$ & 3 & 2.1 & 1 & 0.7 & 19 & 13.6 & 72 & 51.4 & 45 & 32.1 & 4.11 \\
\hline $\begin{array}{l}\text { My institution provides writing } \\
\text { support for international students that } \\
\text { goes beyond grammar and emphasize } \\
\text { disciplinary content and context. }\end{array}$ & 0 & 0.0 & 0 & 0.0 & 1 & 0.7 & 61 & 44.2 & 76 & 55.1 & 4.54 \\
\hline $\begin{array}{l}\text { My institution provides opportunities } \\
\text { for international students to interact } \\
\text { with faculty members outside of class. }\end{array}$ & 3 & 2.2 & 0 & 0.0 & 6 & 4.3 & 70 & 50.7 & 59 & 42.8 & 4.32 \\
\hline $\begin{array}{l}\text { My institution helps international } \\
\text { students find part-time assistantships } \\
\text { or employment on campus. }\end{array}$ & 1 & 0.7 & 0 & 0.0 & 9 & 6.6 & 73 & 53.3 & 54 & 39.4 & 4.31 \\
\hline
\end{tabular}

(Table Continues) 


\begin{tabular}{|c|c|c|c|c|c|c|c|c|c|c|c|}
\hline \multirow[b]{2}{*}{ Survey Questions } & \multicolumn{2}{|c|}{ Don't know } & \multicolumn{2}{|c|}{$\begin{array}{l}\text { Strongly } \\
\text { disagree }\end{array}$} & \multicolumn{2}{|c|}{ Disagree } & \multicolumn{2}{|c|}{ Agree } & \multicolumn{2}{|c|}{ Strongly agree } & \multirow[t]{2}{*}{ Mean } \\
\hline & $n$ & $\%$ & $n$ & $\%$ & $n$ & $\%$ & $n$ & $\%$ & $n$ & $\%$ & \\
\hline \multicolumn{12}{|l|}{$\begin{array}{l}\text { Intercultural and Global Competency } \\
\text { (IGC) }\end{array}$} \\
\hline $\begin{array}{l}\text { My institution provides faculty } \\
\text { members with training on how } \\
\text { American classrooms and } \\
\text { instructional techniques differ from } \\
\text { what international students have been } \\
\text { used to in their home countries }\end{array}$ & 3 & 2.1 & 0 & 0.0 & 0 & 0.0 & 54 & 38.6 & 83 & 59.3 & 4.53 \\
\hline $\begin{array}{l}\text { My institution provides training in } \\
\text { intercultural competence for faculty } \\
\text { and staff who work with international } \\
\text { students. }\end{array}$ & 2 & 1.4 & 0) & 0.0 & 1) & 0.7 & 38 & 27.3 & 98 & 70.5 & 4.65 \\
\hline $\begin{array}{l}\text { My institution includes intercultural } \\
\text { competence as a criterion in } \\
\text { performance appraisals of faculty and } \\
\text { staff who work with international } \\
\text { students. }\end{array}$ & 7 & 5.0 & 0) & 0.0 & 12 & 8.5 & 62 & 44.0 & 62 & 42.6 & 4.19 \\
\hline
\end{tabular}

(Table Continues) 


\begin{tabular}{|c|c|c|c|c|c|c|}
\hline & Don't know & $\begin{array}{l}\text { Strongly } \\
\text { disagree }\end{array}$ & Disagree & Agree & Strongly agree & Mean \\
\hline Survey Questions & $\%$ & $\%$ & $\%$ & $\%$ & $\%$ & \\
\hline
\end{tabular}

My institution assures that courses throughout the curriculum build the intercultural competencies of both domestic and international students.

0

0

cultural insensitivity, racial biases, or prejudice

\section{Institutional Leadership and Support} (ILS)

My institution has a strategic plan for international student services or includes international student services in the strategic plan of student affairs

My institution's budget includes monies that are specifically targeted for international student services.

$\begin{array}{lllllllllll}0 & 0.0 & 2 & 1.4 & 2 & 1.4 & 46 & 33.3 & 88 & 63.8 & 4.60 \\ 1 & 0.7 & 0 & 0.0 & 0 & 0.0 & 36 & 26.3 & 100 & 73.0 & 4.71\end{array}$




\begin{tabular}{|c|c|c|c|c|c|c|c|c|c|c|c|}
\hline \multirow[b]{2}{*}{ Survey Questions } & \multicolumn{2}{|c|}{ Don't know } & \multicolumn{2}{|c|}{$\begin{array}{l}\text { Strongly } \\
\text { disagree }\end{array}$} & \multicolumn{2}{|c|}{ Disagree } & \multicolumn{2}{|c|}{ Agree } & \multicolumn{2}{|c|}{ Strongly agree } & \multirow[t]{2}{*}{ Mean } \\
\hline & $n$ & $\%$ & $n$ & $\%$ & $n$ & $\%$ & $n$ & $\%$ & $n$ & $\%$ & \\
\hline $\begin{array}{l}\text { My institution has an office that } \\
\text { coordinates support services for } \\
\text { international students }\end{array}$ & 0 & 0.0 & 0 & 0.0 & 0 & 0.0 & 19 & 14.1 & 116 & 85.9 & 4.86 \\
\hline $\begin{array}{l}\text { My institution adequately staffs } \\
\text { international student offices or } \\
\text { international student affairs offices. }\end{array}$ & 0 & 0.0 & 1 & 0.7 & 0 & 0.0 & 34 & 24.5 & 104 & 74.8 & 4.73 \\
\hline $\begin{array}{l}\text { My institution hires personnel in } \\
\text { international student offices or } \\
\text { international student affairs units who } \\
\text { have previous experience working } \\
\text { with international students. }\end{array}$ & 1 & 0.7 & 0 & 0.0 & 4 & 3.0 & 35 & 25.9 & 95 & 70.4 & 4.65 \\
\hline $\begin{array}{l}\text { My institution helps international } \\
\text { students overcome any reluctance they } \\
\text { might have to access counseling } \\
\text { services (e.g., mental health services. }\end{array}$ & 0 & 0.0 & 0 & 0.0 & 0 & 0.0 & 5 & 40.1 & 82 & 59.9 & 4.60 \\
\hline $\begin{array}{l}\text { My institution develops religiously } \\
\text { affiliated centers for international } \\
\text { students, recognizing that their cultural } \\
\text { needs may be different from those of } \\
\text { domestic students. }\end{array}$ & 8 & 5.7 & 5 & 3.6 & 14 & 10.0 & 72 & 51.4 & 41 & 29.3 & 3.95 \\
\hline
\end{tabular}




\section{Research Question 3: Is There a Gap Between What Services Student Services Personnel Perceive That Their Institutions Are Providing and What Services Should Be Provided?}

The third and final research question focused on gaps in the services that are currently being offered and those that the respondents feel should be offered. The responses under each category (i.e., SES, IGC and ILS) were analyzed.

\section{Student Engagement and Services (SES)}

Practices under the SES category were analyzed based on the differences in mean scores of the responses to 'as is' and 'should be' scenarios. A summary of the mean scores and their differences for the statements in the SES category is presented in Table 9. The results of twotailed $t$-tests for all items $(\mathrm{n}=7)$ under the SES category suggest, overall, a difference between perceptions of actual versus ideal practices. The magnitude of gaps for each paired statement varied, ranging from a high of 1.28 for the statement concerning surveying international students about their preferences for receiving information from institutions, to a low of 0.28 concerning the extent to which institutions help students find part-time assistantships.

A distinct gap in perceptions of actual versus desired practice can be observed in statements for which mean "as-is" scores are below 4 and mean "should be" scores are above 4. This applies to statements regarding the assessment of student satisfaction with institutional services; the provision of extended, semester-long orientations; the availability of intense writing support; and opportunities for international students to interact with faculty members outside of class. Respondents perceive that their institutions need to enhance their efforts in these areas. On the other hand, the respondents were confident that their institutions were appropriately attending to two practices recommended in the literature: providing pre-arrival information to 
international students and providing assistance in finding a part-time job on campus. The mean score differences for statements related to these practices are relatively low.

Appendix F provides the responses by institutional type for the statement pairs in the SES category. The data mirror the overall findings discussed above, with few differences between public and private institutions.

\section{Institutional Leadership and Support (ILS)}

Table 10 compares the means of "as is" responses to the means of "should be" responses for 7 paired statements under the institutional leadership and support category. The respondents felt that their institutions can do a better job in all of the services and practices reflected in these statements. However, responses indicate relatively large concern in two areas: staffing adequacy in campus offices devoted to international students and the development of a strategic plan for international student services (or the inclusion of international students in strategic plans for student affairs generally). The difference between mean "as is" and mean "should be" scores for both areas was greater than one. 
Table 9

Comparison of Mean “As Is" Responses to "Should Be” Responses: Student Engagement and Services Category

\begin{tabular}{|c|c|c|c|}
\hline Questionnaire items & $\begin{array}{l}\text { (A) } \\
\text { Mean "as } \\
\text { is" response }\end{array}$ & $\begin{array}{c}\text { (B) } \\
\text { Mean } \\
\text { "should } \\
\text { be" } \\
\text { response }\end{array}$ & $(\mathrm{B}-\mathrm{A})$ \\
\hline $\begin{array}{l}\text { My institution surveys/should survey international students to understand how frequently they } \\
\text { would prefer to receive information from the institution }\end{array}$ & 2.64 & 3.92 & 1.28 \\
\hline $\begin{array}{l}\text { My institution assesses/should assess the extent to which international students are satisfied } \\
\text { with campus support services. }\end{array}$ & 3.60 & 4.56 & 0.96 \\
\hline $\begin{array}{l}\text { My institution provides/should provide pre-engagement (i.e., pre-arrival information for } \\
\text { international students on academics, social and cultural differences in the U.S., even before } \\
\text { they leave their home countries }\end{array}$ & 4.24 & 4.71 & 0.47 \\
\hline $\begin{array}{l}\text { My institution provides/should provide extended, semester-long orientations for international } \\
\text { students during their first months at the institution. }\end{array}$ & 3.24 & 4.11 & 0.87 \\
\hline $\begin{array}{l}\text { My institution provides/should provide writing support for international students that goes } \\
\text { beyond grammar and emphasize disciplinary content and context. }\end{array}$ & 3.95 & 4.54 & 0.59 \\
\hline $\begin{array}{l}\text { My institution provides/should provide opportunities for international students to interact with } \\
\text { faculty members outside of class. }\end{array}$ & 3.77 & 4.32 & 0.55 \\
\hline $\begin{array}{l}\text { My institution helps/should help international students find part-time assistantships or } \\
\text { employment on campus. }\end{array}$ & 4.03 & 4.31 & 0.28 \\
\hline All items in category combined & 3.63 & 4.35 & 0.72 \\
\hline
\end{tabular}

${ }^{\mathrm{a}} t(7)=2.44, p=.001$ 
Table 10

Comparison of Mean “As Is" Responses to "Should Be" Responses: Institutional Leadership and Support Category

\begin{tabular}{|c|c|c|c|}
\hline Questionnaire items & $\begin{array}{l}\text { (A) } \\
\text { Mean "as is" } \\
\text { response }\end{array}$ & $\begin{array}{l}\text { (B) } \\
\text { Mean } \\
\text { "should be" } \\
\text { response }\end{array}$ & $(\mathrm{B}-\mathrm{A})$ \\
\hline $\begin{array}{l}\text { My institution helps international students overcome any reluctance they might } \\
\text { have to access counseling services (e.g., mental health services. }\end{array}$ & 4.01 & 4.60 & 0.59 \\
\hline $\begin{array}{l}\text { My institution develops religiously affiliated centers for international students, } \\
\text { recognizing that their cultural needs may be different from those of domestic } \\
\text { students. }\end{array}$ & 3.35 & 3.95 & 0.60 \\
\hline $\begin{array}{l}\text { My institution has a strategic plan for international student services or includes } \\
\text { international student services in the strategic plan of student affairs. }\end{array}$ & 3.56 & 4.59 & 1.03 \\
\hline $\begin{array}{l}\text { My institution's budget includes monies that are specifically targeted for } \\
\text { international student services. }\end{array}$ & 3.95 & 4.71 & 0.76 \\
\hline $\begin{array}{l}\text { My institution has an office that coordinates support services for international } \\
\text { students. }\end{array}$ & 4.66 & 4.86 & 0.20 \\
\hline $\begin{array}{l}\text { My institution adequately staffs international student offices or international } \\
\text { student affairs offices. }\end{array}$ & 3.47 & 4.73 & 1.26 \\
\hline $\begin{array}{l}\text { My institution hires personnel in international student offices or international } \\
\text { student affairs units who have previous experience working with international } \\
\text { students. }\end{array}$ & 4.25 & 4.65 & 0.40 \\
\hline All items in category combined ${ }^{\mathrm{a}}$ & 3.89 & 4.58 & \\
\hline
\end{tabular}

${ }^{\mathrm{a}} t(7)=2.44, p=.000$ 
Analyzing responses by institutional type yields interesting findings (Appendix G). First, at least one third of the respondents indicated that that their institutions or serving international students. In addition, about $50 \%$ respondents at both public and private institutions perceived that international student offices on their campuses were inadequately staffed. Furthermore, many respondents $(49.4 \%$ of those from public institutions and $33.3 \%$ of those from private institutions) indicated that religiously affiliated centers are currently not available at their universities. But approximately $80 \%$ of the respondents at public institutions and nonprofit private institutions agreed that these centers should be should implemented at their institutions. Almost all the respondents indicated that their universities have a separate office that coordinates student support services. However, only $1.1 \%$ of the respondents from public institutions agreed that university budgets included monies for international student services, compared to $90.4 \%$ of respondents from private, nonprofit institutions.

\section{Intercultural and Global Competence (IGC)}

It is in the area of intercultural and global competence that the largest gaps emerged between "as is" and "should be" ratings. The gaps for all statements in this area were larger than 1 (Table 11). The respondents seemed particularly concerned that their institutions can do a better job in including intercultural competence in staff faculty performance appraisals, providing training in intercultural competence for staff and faculty, and assuring that that courses throughout the curriculum build the intercultural competencies of both domestic and international students. These concerns were shared across institutional sectors (See Appendix H). 
Table 11

Comparison of Mean "As Is" Responses to "Should Be" Responses: Intercultural and Global Competence

\begin{tabular}{|c|c|c|c|}
\hline Questionnaire items & $\begin{array}{l}(\mathrm{A}) \\
\text { Mean "as is" } \\
\text { response }\end{array}$ & $\begin{array}{l}\text { (B) } \\
\text { Mean } \\
\text { "should be" } \\
\text { response }\end{array}$ & $(\mathrm{B}-\mathrm{A})$ \\
\hline $\begin{array}{l}\text { My institution provides faculty members with training on how American } \\
\text { classrooms and instructional techniques differ from what international students } \\
\text { have been used to in their home countries }\end{array}$ & 3.19 & 4.53 & 1.34 \\
\hline $\begin{array}{l}\text { My institution provides training in intercultural competence for faculty and staff } \\
\text { who work with international students. }\end{array}$ & 3.23 & 4.65 & 1.42 \\
\hline $\begin{array}{l}\text { My institution includes intercultural competence as a criterion in performance } \\
\text { appraisals of faculty and staff who work with international students. }\end{array}$ & 2.26 & 4.19 & 1.93 \\
\hline $\begin{array}{l}\text { My institution assures that courses throughout the curriculum build the } \\
\text { intercultural competencies of both domestic and international students. }\end{array}$ & 3.08 & 4.47 & 1.39 \\
\hline $\begin{array}{l}\text { My institution intervenes in an appropriate manner when faculty and staff engage } \\
\text { in behaviors that show cultural insensitivity, racial biases, or prejudice. }\end{array}$ & 3.60 & 4.65 & 1.05 \\
\hline All items in category combined ${ }^{\mathrm{a}}$ & 3.07 & 4.50 & \\
\hline
\end{tabular}

${ }^{\mathrm{a}} t(5)=2.44, p=.000$ 


\section{Summary}

Overall, responses to statements in all three categories-SES, IGC, and ILS - reveal the respondent's view that their institutions should continue to improve their services for international students. This reflects the need for continuous improvement. As Cohen, Brawer and Kisker (2013) put it, the nature of education is "infinite. We can always teach more, learn more efficiently, do better" (p. 434). However, study findings reveal that respondents were most concerned about institutional efforts to promote intercultural competence as a way of serving international students. This can be seen below in Table 12, which shows that the survey statements generating the largest differences between "as is" and "should be" responses fell into the IGC domain. The next chapter examines the implications of these and other findings.

Table 12

Statement Pairs Arranged by Descending Order of Difference of Means

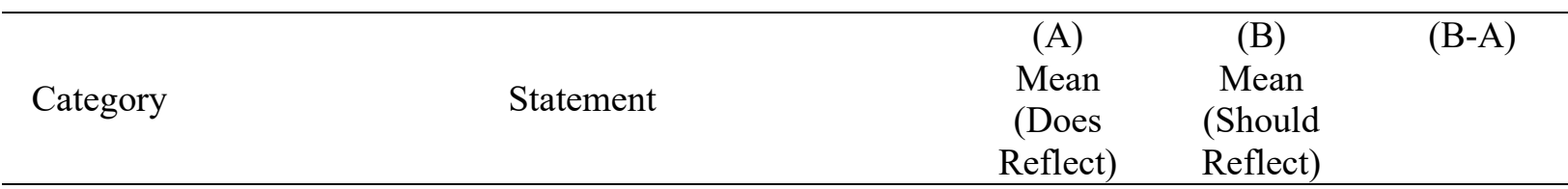

My institution includes/should include

$\begin{array}{lllll}\text { IGC } & \begin{array}{l}\text { intercultural competence as a criterion in } \\ \text { performance appraisals of faculty and staff who }\end{array} & 2.26 & 4.19 & 1.93\end{array}$

work with international students.

My institution provides/should provide training

IGC in intercultural competence for faculty and staff who work with international students.

My institution assures/should assure that courses throughout the curriculum build the IGC intercultural competencies of both domestic and international students. 


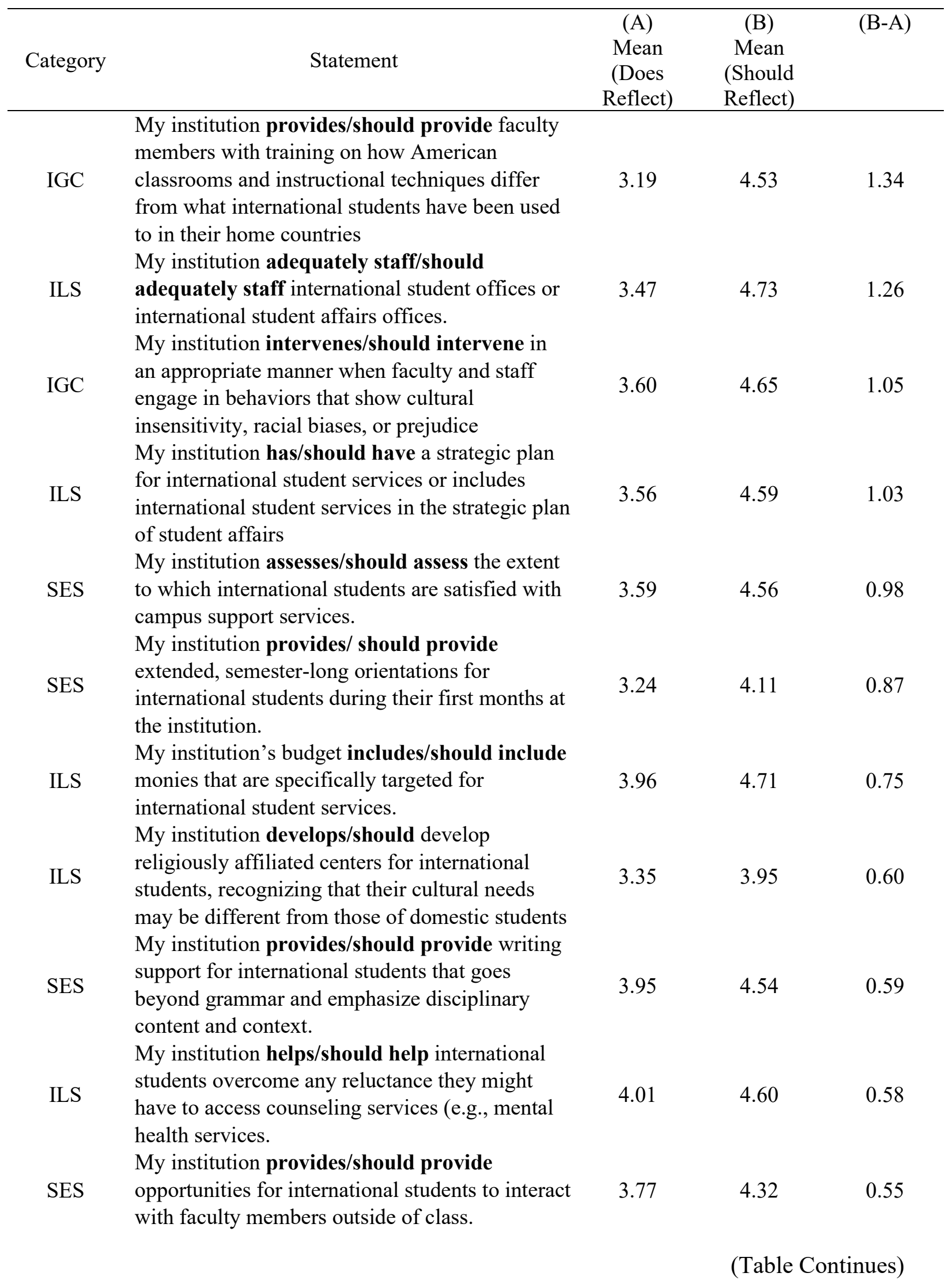




\begin{tabular}{|c|c|c|c|c|}
\hline Category & Statement & $\begin{array}{l}\text { (A) } \\
\text { Mean } \\
\text { (Does } \\
\text { Reflect) }\end{array}$ & $\begin{array}{l}\text { (B) } \\
\text { Mean } \\
\text { (Should } \\
\text { Reflect) } \\
\end{array}$ & (B-A) \\
\hline SES & $\begin{array}{l}\text { My institution provides/ should provide pre- } \\
\text { engagement (i.e., pre-arrival information for } \\
\text { international students on academics, social and } \\
\text { cultural differences in the U.S., even before they } \\
\text { leave their home countries }\end{array}$ & 4.24 & 4.71 & 0.47 \\
\hline ILS & $\begin{array}{l}\text { My institution hires/should hire personnel in } \\
\text { international student offices or international student } \\
\text { affairs units who have previous experience working } \\
\text { with international students. }\end{array}$ & 4.25 & 4.65 & 0.40 \\
\hline SES & $\begin{array}{l}\text { My institution surveys international students to } \\
\text { understand how frequently they would prefer to } \\
\text { receive information from the institution }\end{array}$ & 4.26 & 4.58 & 0.32 \\
\hline SES & $\begin{array}{l}\text { My institution helps/should help international } \\
\text { students find part-time assistantships or employment } \\
\text { on campus }\end{array}$ & 4.03 & 4.31 & 0.28 \\
\hline ILS & $\begin{array}{l}\text { My institution has/should have an office that } \\
\text { coordinates support services for international students }\end{array}$ & 4.66 & 4.86 & 0.19 \\
\hline
\end{tabular}


In this chapter, the researcher presented an analysis of findings of the online survey. Descriptive and correlational statistics explained the quantitative findings. The survey accomplished the goal of answering the research questions, 1) What services do student services personnel perceive that their institutions are providing for international students?, 2) What services do student services personnel perceive that their institutions should be providing for international students?, 3) Is there a gap between what services student services personnel perceive that their institutions are providing and what services should be provided?

These gaps in practices have serious implications for the future of international student services which will be discussed in the next chapter. 


\section{CHAPTER V: IMPLICATIONS AND CONCLUSION}

In this exploratory study, the researcher examined the campus services for international students at universities in the Midwest. Data was collected in an online survey sent to 272 international student services personnel in 190 public, 82 private universities in the Midwest; 147 responded. The respondents were asked to rate their agreement to 21 paired statements regarding international student services that were identified in the literature as important for international students. The respondents indicated their level of agreement that the statements reflect current practice at their institutions as well as their level of agreement that the statements reflect practices that their institutions should undertake. The survey also included two background questions on the type of institutions at which the respondents were employed (i.e., four-year public, four-year private non-profit, or four-year private for-profit) and on the total number of international students enrolled in their institutions. The survey was designed to answer the following research questions:

1. What services do student services personnel perceive that their institutions are providing for international students?

2. What services do student services personnel perceive that their institutions should be providing for international students?

3. Is there a gap between what services student services personnel perceive that their institutions are providing and what services should be provided?

Survey results enabled the researcher to assess the perceived gap between what universities are doing to help international students and what they should be doing. Results indicate that the international student services personnel are generally positive about the campus services at their but have an especially strong desire to enhance the intercultural and global 
competence of faculty and staff. In this chapter, the researcher discusses the implications of these findings in the two domains of (a) faculty and Staff, and (b) students. The chapter concludes with recommendations for future research.

\section{Faculty and Staff}

The study's key finding was in the area of intercultural and global competency, a domain in which respondents perceived the greatest gaps between actual and desired practice. Table 12 (in Chapter Four) highlights this finding, demonstrating that the four statements with the highest differences in mean ratings of actual versus desired practices were in the intercultural and global competency category. This aligns with Deardorff's (2004) assertion that only a few U.S. universities consider intercultural competency development as a part of their internationalization process. The issue is compounded, as Deardorff (2004) says, by the confusion in defining the concept of intercultural competency, determining the skills it entails, and measuring or documenting competency in these skills. Although institutions in the United States have been striving to create global campuses by recruiting many international students, as the survey suggests, institutions may still have to rethink their modus operandi on developing interculturally competent staff, faculty, and students. The findings suggest that greater attention may need to be devoted to training, performance appraisal, and curriculum development.

\section{Intercultural Competence Training and Curriculum Development}

An interesting finding in this study is that almost half (45.9\%) of the respondents disagreed or strongly disagreed that their institutions enhance the intercultural competency of faculty and staff through appropriate training; similarly, $48.3 \%$ of the respondents disagreed or disagreed strongly their institutions may train faculty members on how American classrooms 
and instructional techniques differ from what international students have been used to in their home countries (see Table 6 in Chapter Four).

This suggests that institutions might need to develop more training programs for faculty and staff and may need to incorporate this training in their strategic plans as a way of assuring that it is formally adopted and acted on by the entire institution. The implication resonates with the literature highlighting intercultural training as the key to better serving international students on campus (e.g., Chen \& Yang, 2014; Koseva, 2017; Mcfarlene, 2015; Ngyuen \& Larson, 2017; Sherry, Thomas \& Chui, 2009). If faculty and staff are unable to perceive the unique needs of international students, the academic, social, cultural, and personal challenges of international students may remain unmet. Bennet (1993) observed that many people often have a monocultural world view and are unable to identify the differences among various cultures. Because people bring in misconceptions about other cultures or are encased in their own frames of reference, they must be trained to identify cultural differences and become conscious of their untoward judgements of those from other cultures. As Lee Olson and Kroeger (2001) recommend, faculty and staff must be trained in other languages and culture if they are to be more ethnorelative in their interactions with international students. Bennett (1993) asserts the importance of intercultural sensitivity whereby individuals understand even subtle cultural differences, both verbal and non-verbal. Such intercultural communication skills cannot be learned overnight. But attempts must be made to help faculty and staff move from a monocultural world view (their own culture) to an intercultural world view (appreciation of other cultures).

Thus, many respondents in this study were concerned about the current state of intercultural competence training programs for faculty and staff at their institutions. These perceptions on intercultural and global competency development imply that institutions might 
benefit to the extent that more resources and planning dedicated toward action plans for sequenced and targeted faculty and staff training. This in turn may point to needed modifications in organizational vision and mission, that may need to be modified if a strong commitment to developing staff and faculty intercultural and global competence. The introduction of an organization-wide to intercultural and global competency development may also raise several questions and challenges for institutional leaders.

Who should be trained? The survey asked for perceptions of institutional efforts to train staff and faculty on intercultural competencies. However, leaders might want to think about which faculty and staff should be trained. For instance, staff working at the international student services offices may need mandatory training. But as institutions increase campus-wide internationalization efforts and recruit more international students, staff across the campus need intercultural competency development. In this case, how should leaders decide which staff need to be trained? Andrew (2012) draws on Stella and Liston's (2007) recommendations for mandatory baseline training for all staff and thus advises that institutions should embed training in staff induction programs and provide it as a career development program as well. In line with this recommendation, institutional leaders may need to incorporate training modules for staff and faculty across the institution.

Likewise, leaders might consider rolling out the training programs to all faculty. Since interculturally competent faculty are more sensitive to different learning styles of students (Bichelmeyer \& Cagiltay, 2000), it is important that leaders rethink the professional development modules for faculty. However, which faculty should be trained is a contentious topic of discussion? Because international students tend to choose STEM courses at the institutions (National Science Foundation, 2015), faculty teaching non-STEM courses may argue that these 
trainings are not essential for them. However, when an institution is centered on providing a globalized education campus wide, an argument can be made that faculty across all departments should be equipped with intercultural training. In order to enhance the positive interactions between domestic and international students and to mitigate the social and cultural challenges faced by international students, training should be designed to enhance intercultural and global knowledge.

Intercultural training provides the necessary impetus for faculty to refine their curriculum in ways that enhance the intercultural competence of students. A key finding in this study is that only $44.6 \%$ of the respondents agree or strongly agree that their institutions incorporate curriculum that builds intercultural and global competencies for both domestic and international students. A slightly smaller percentage (38.3\%) disagree or strongly disagree, whileinterestingly $-17.1 \%$ are unaware of the extent to which this practice characterizes curricula at their institutions. The perception of gaps between the actual and desired extent to which curricula at the respondents' universities are internationalized has potentially serious implications for student learning and experience.

Before leaders choose to incorporate intercultural training for faculty, they should address the misconceptions about intercultural learning in classrooms. A common misconception is that recruiting international students who can share their experiences with other students in the classroom is sufficient to internationalize the curriculum (Leask, 2015). Hence, defining what internationalizing the curriculum entails is an important first step as leaders start the process. According to Leask (2009), internationalizing the curriculum is "the incorporation of international, intercultural, and/or global dimensions into the content of the curriculum as well as 
the learning outcomes, assessment tasks, teaching methods, and support services of a program of study" (p. 209).

What formats (in-person, online etc.) should be used? Another question that leaders should consider is the format in which training should be delivered. Scholars recommend a faceto-face training involving group discussions, case studies, and role-plays (Andrew, 2012; Gopal, 2011). Training should be customized with tailored modules that meet the needs of various staff since not all staff are directly involved with international students. In addition, mandatory basic intercultural training should be provided for all new staff (Andrew, 2012). Higher education leaders should emphasize the importance of culturally responsive teaching; one successful example of faculty development in this area is presented by Mayo and Lark (2011), who describe the Multicultural Curriculum Transformation and Research Institute at a Texas university, which trains faculty in the development of multicultural curricula. The training sessions are week-long, include consultants and guest scholars, and encourage faculty to share their expertise and multicultural perspectives on strategies, classroom dynamics, and assessment. Faculty share their concerns in breakout sessions and learn from others how to incorporate multicultural content and teaching methods. This successful training and professional development program have been ongoing for five years. This example of face-to-face training could be mirrored by other institutional leaders considering faculty training for intercultural curriculum development.

How might leaders build faculty buy-in? Currently institutions implement mandatory training programs across all university constituents on such topics as Title IX and ethics. Institutional leaders have made these trainings mandatory so that the university is compliant with Title IX rules and other regulations. Likewise, IRB training and certifications have been mandatory as a way of assuring that researchers understand the rights of human subjects. These 
practices, though enforced in the beginning, become habitual and then a norm in most settings (S. Amirali, personal communication, March 16, 2020). However, not all trainings and novel practices can be enforced at university settings; requires faculty buy-in must be secured. Ewell (2005) asserts the importance of faculty buy-in for the success of any program. Increasing accountability among faculty and staff often leaders to seek a balance between institutional mandates and the faculty member's academic freedom. Hence, leaders contemplating intercultural training programs, curriculum changes, or evaluations of faculty intercultural competence should consider strategies for securing faculty support of these initiatives. Authors have identified several factors, described below, that influence faculty to committing to tasks such as training or other programs.

Personal value. One such influencing factor is the personal value that faculty attribute to participation in a university initiative, such as training. (Sujitparapitaya, 2014). According to Sujitparapitaya (2014), value personal can stem from curiosity about a topic or the perceived value faculty accrue through participation in training, such as fulfilling requirements for tenure or promotion. Understanding what motivates faculty to embrace training programs and implement curricular reforms is crucial.

Break silos. Although international students have contact with almost all departments on campus, the lack of coordination among these departments restrains the intercultural development of staff, faculty and students. Several survey respondents chose "Don't Know" when asked about institutional practices described in the questionnaire statements. For the most part, "don't know" responses (as a \% of responses) tended to be low (0-7\%), and those that were high (i.e., $30 \%$ or higher as I the case whether or not faculty are evaluated on the basis of cultural competency) reflect the limits of what student services people might reasonably know on 
campus. Interestingly, this may reflect two key insights. First, the student services world and the faculty world are often quite separate with little or no coordination or communication. The international student services administrators work in silos as do other departmental units on campus. Second, the university leadership should consider incorporating all constituencies in international education, including faculty and staff. This, with a strong leadership that breaks down silos and increases collaboration among departments, would eventually usher in a new era of globalized campuses that produce global citizens.

Leaders who want to bring about change in the current processes should consider starting this change at the departmental levels. The inclusion of an intercultural dimension in the performance appraisal process for staff and faculty, especially in relation to work on curriculum changes, demands cross-departmental collaboration and implies a system-wide change in the how universities operate. Therefore, leaders ought to consider participatory action research, which, as McTaggart (1989) points out, begins with "minor changes which individuals can manage and control, and ... [works] towards more extensive patterns of change" (para. 12). Thus, experimentation with changes or operations at the departmental level within the organization can lead to system-wide changes in policies and programs. Efforts within each department to include intercultural dimensions in their appraisal processes could spur organization-wide change that leads all faculty and staff to become more sensitive to other cultures. However, department chairs initiating these changes may face push-back from faculty who value their autonomy and academic freedom. Although research suggests that the tension between department chairs and faculty members may throw a wrench in change processes, department chairs, as key facilitators of change, can overcome resistance by engaging faculty in 
the change process, empowering them to take part in decision-making, nurturing and understanding their needs, and creating an atmosphere of trust (McArthur, 2002).

Institutional support. Finally, although organization-wide change will emerge from the ground up as units within the university experiment with innovations in curriculum and performance appraisal, the impetus for pulling off such a massive overhaul of institutional processes should initiate from and be supported by the leadership: presidents, provosts, deans, department heads ,and chairs. Indeed, the importance of institutional leadership and support has been emphasized by many writers (e.g., Childress, 2009; Hudzik, 2011; Rumbley, Altbach \& Reisberg, 2012). Those leaders investigating the change policies should consider, according to Polyak, Kery, and Tardos (2013), an organizational vision, the commitment of top management, an audit and assessment of needs, clarity of objectives, clear accountability, effective communication, co-ordination of activities, and evaluation.

Instituting an organizational vision that encompasses diversity and interculturalism as one of the core values provides the impetus for change and enhances accountability among its constituents (Mayo \& Lark, 2011). Just over one third (36.3\%) of the respondents in this study perceived that their institutions operate without a university-wide strategic plan that includes international student services (Table 7 in Chapter Four). This finding raises serious questions about how departments within some institutions coordinate services for international students and how action plans for these services are developed and carried out. Without a strategic plan to give importance to international student services, the question of who is accountable or responsible for providing suitable services for international students remains unanswered.

This finding also suggests that the recruitment of international students at some universities may be viewed primarily from an economic, revenue-generating perspective 
(Knight, 2004). With the large number of students entering U.S. universities, this lack of institutional commitment to larger, educational aims may only lead to a sad situation for international students on campus. Although it is apparent that there is a widespread move towards internationalization among higher education institutions, the perceived gaps between actual and desired practice revealed in this study suggest that we still have a long way to go. Variations across institutions in terms of campus internationalization efforts may potentially be attributed to several factors including a lack of strategic planning, a lack of support and commitment by administrators towards international education (De Wit, 2002; Knight, 2004), and a lack of a campus-wide understanding of internationalization strategy (Childress, 2009).

The gap perceived by many respondents between actual and desired practice regarding strategic planning for service to international students suggests the presence of other shortfalls in campus internationalization. Among other organizational deficits, internationalization activities might be confined to a rather narrow definition of what international students may need as opposed to what they actually need. The study also suggested a need at some institutions for leadership efforts that enhance collaboration among departmental units in several areas such as training in intercultural competency, incorporating intercultural competency in staff and faculty performance appraisals, and developing an internationalized curriculum. In order to close these gaps, campus leaders should initiate a campus-wide strategic plan to include international student services as one of the key themes to be covered. This would render all university constituents accountable, help establish priorities and programs, develop regular assessment processes, and direct appropriate funding for the services. 


\section{Students}

\section{Student Satisfaction}

Respondent perceptions of institutional communications with international students reflected a potential area of concern. A major finding is that only $17.7 \%$ of the respondents agreed or strongly agreed that their institutions survey students to determine preferences for how

frequently students would like to receive information the university (Table 5 in Chapter Four). Many respondents were also concerned about a perceived lack of effort in assessing student satisfaction with institutional services. Most (61.2\%) agreed or strongly agreed felt that their institutions assess the extent to which international students are satisfied with services, but a sizable minority (37.4\%) disagreed or disagreed strongly. Without knowing the communication preferences of students or the extent to which current services meet student needs, institutions cannot effectively refine their programs or offerings. Regularly surveying international students would help institutions improve the situation. Furthermore, the survey can be developed on freely available survey platforms such as SurveyMonkey and distributed through the institutional e-mails, thus involving negligible costs and time. does not involve additional cost or resources and can be easily implemented every semester.

\section{Semester-Long Orientations}

Another key finding is that most respondents (63.4\%) disagreed or strongly disagreed that their institutions provide international students with semester-long orientations. In contrast, however, only $12.2 \%$ disagreed or disagreed strongly that their institutions provide international students with pre-arrival information, and only $20.4 \%$ disagreed or disagreed strongly that their institutions help international students find part-time assistantships or employment on campus. 
The findings therefore suggest that while the universities at which the respondents were employed tended to provide pre-arrival orientation and access to campus assistantships or employment, they may not be as likely to provide intensive orientations once international students arrive on campus. This can be resolved by offering semester-long orientation programs or orientation courses that provide a streamlined approach to help international students during their first few months after arrival on an alien land.

Institutional leaders looking at implementing semester-long orientations for international students can draw on best practices from several institutions across the United States. Such innovative orientations, according to The Centre for Global Education (2014), are currently provided by College of St. Benedict, St. John's University, Northern Arizona University, University of California at Los Angeles (UCLA).

College of St. Benedict and St. John's University provide a 12-week cultural/academic orientation course for international students to understand the cultural adjustment and strategies to help them acclimatize to life in the U.S. (College of St. Benedict \& St. John's University, n.d.). Furthermore, this course provides training on the various campus services available to international students, including immigration, health services, library, course registration, security and so on. The course is not graded, however is recommended for new and transfer international students.

Northern Arizona University offers an 8-week transition course on international student success. The course covers academic resources, integrity, immigration, and U.S. culture (Northern Arizona University, 2020). With only a letter grade, this course aims to provide the necessary information for international students to succeed on campus. 
The University of California at Lost Angeles (UCLA, 2020) offers international students a seminar-type course that imparts critical strategies for achieving undergraduate excellence. This pass/no pass course is designed to help international undergraduate students transition to the U.S. by helping them navigate campus resources, policies, and procedures.

Institutional leaders instituting such long-term orientation courses for incoming international students might face staffing challenges. Indeed, most of the respondents (52.4\%) perceived that offices devoted to international students on their campuses were inadequately staffed. Inadequate staff to carry out these practices may hinder successful implementation of these innovative orientation options. In addition, inadequate staffing might impede other international student services such as mental health counselling, immigration services, and career services.

Although campus internationalization has been gaining traction in recent years owing to shifting demographics and globalization, Osfield (2008) believes "[Internationalization]...is a term often thrown into the mission statements of institutions for accreditation purposes but that schools often lack the significant resources and administrative staff needed to entrench it in campus life" (p.4). Poyrazli and Grahame (2007) attest to the role of student services staff in enhancing the experiences of international students. Exploring this thought further, other than the obvious reasons of funding cuts, several other factors — such as insufficient training and a lack of interculturally competent faculty and staff-form obstacles towards campus internationalization.

Furthermore, half of the respondents perceived the need for religiously affiliated centers for international students, perhaps as a way of helping these students overcome some of the fear and cultural challenges associated with being in a new country. With the increasing student 
mobility, changing demographics, and increasing competition, it is imperative that institutions extend their campus services to include newer and more comprehensive modes of assistance.

\section{Implications for Future Research}

The study findings and implications center on almost half of the survey respondents perceiving a need for their institutions to ramp up training for faculty and staff on intercultural competencies. Although the study has revealed certain gaps in these areas, several questions remain unanswered, of which the most important is why these student affairs professionals responded the way they did. Their perceptions, though helpful in identifying ways that institutions can enhance campus internationalization activities, do not throw light on the underlying systemic issues that prevail in higher education institutions.

Therefore, a future study to augment our current understanding of international student services would entail a qualitative analysis of these student affairs professionals, asking them through interviews or focused group discussions, to explain the gaps they perceive in actual versus desired practices. These professionals, when interviewed, can throw light on the workings of institutions as they implement and carry out programs for international students, explaining the and the challenges associated with this work. Since intercultural competence training and programming emerged as a concern for the student affairs professionals responding to this survey, a qualitative analysis would probably clarify the reasoning behind this concern and help unearth the attitudes, governance, and leadership styles needed to improve enhance competency training. Such a study may also help identify ways of connecting faculty and administrators in collaborative efforts on behalf of students.

Another future study would entail a replication of the current study, but this time surveying international students at Midwestern universities. Understanding the needs of the 
students and their perceptions of how campus services help or fall short in meeting those needs would offer valuable insights. A follow-up qualitative analysis could then be conducted, helping us understand why the students responded as they did and, in the process, offering insights into how students perceive their experiences and how institutional services affect those experiences. This mixed method could yield important insights for designing more effective campus internationalization programs and services.

Finally, faculty perceptions of intercultural training and curriculum development constitute an important area that needs to be studied. because this study gathered the perceptions of those leading student services efforts, it is imperative to understand how the faculty perceive the need for intercultural training and enhanced efforts to globalize the curriculum. This study also leaves us with questions on what barriers leaders face when advocating for intercultural competency training and a more internationalized curriculum.

Such questions can only be answered through qualitative inquiry, preferably using a phenomenological study design that teases out the perspectives of faculty on intercultural training, curriculum modification, and the incorporation of intercultural competency in performance appraisals. An understanding of these perceptions could help leaders develop strategies for gaining faculty buy-in and support for these practices. Study results could also help leaders avoid unintended and counterproductive consequences of well-intended but ill-planned initiatives that thwart rather than further the institution's work with international students. 


\section{REFERENCES}

Alberts, H. C., \& Hazen, H. D. (Eds.) (2013). International students and scholars in the United States: Coming from abroad. New York: Palgrave Macmillan.

Altbach, P. G. (2016). Global perspectives on higher education. Baltimore, MD: Johns Hopkins University Press.

Altbach, P. G., \& Knight, J. (2007). The internationalization of higher education: Motivations and realities. Journal of Studies in International Education, 11(3-4), 290-305.

Altbach, P. G., \& Peterson, P. M. (1998). Internationalize higher education? Not exactly. Change: The Magazine of Higher Learning, 30(4), 36-39.

Altbach, P. G., \& Salmi, J. (2011). The road to academic excellence: The making of world-class research universities. Washington, DC: World Bank.

Amirali, S., \& Bakken, J. (2015). Trends and challenges of recruiting and retaining international graduate students: An internal perspective. Journal of Education Research, 9, 425-433.

Ammigan, R., \& Laws, K. N. (2018). Communications preferences among international students: Strategies for creating optimal engagement in programs and services. Journal of International Students, 8(3), 1293-1315.

Anayah, B. (2012). International students at community colleges: How are their needs being met? (Doctoral dissertation). Available from ProQuest Dissertations \& Theses Global. (UMI No. 3523622)

Anderson, S. (2018, March 2). Guess who's not coming to America? International students. Forbes. Retrieved from https://www.forbes.com/sites/stuartanderson/2018/03/02/guesswhos-not-coming-to-america-international-students/\#190221603c3e 
Andrade, M. S., \& Evans, N. W. (2009). International students: Strengthening a critical resource. Lanham, MD: Rowman et Littlefield Education.

Andrew, H. (2012, December). Developing intercultural competence in university staff: Augmenting internationalisation. Paper presented at the Joint Australian Association for Research in Education and Asia-Pacific Educational Research Association Conference (AARE-APERA) World Education Research Association (WERA) Focal Meeting, Sydney, New South Wales, Australia. Retrieved from ERIC database: https://eric.ed.gov/?id=ED542345

Arshakian, A., \& Wang, V. (2017). Strategies of supporting Chinese students in an international joint degree program. International Research and Review, 7(1), 54-76.

Astin, A. (1999). Student involvement: A developmental theory for higher education. Journal of College Student Development, 40(5), 518-529. (Original published work 1984).

Atebe, G. M. (2011). An exploratory study on international students' adjustment to American universities. (Doctoral dissertation). Available from ProQuest Dissertations \& Theses Global. (UMI No. 3476402)

Axelson, R. D., \& Flick, A. (2011). Defining student engagement. Change: The Magazine of Higher Learning, 43(1), 38-43.

Banta, T. W. (Ed.). (2002). Building a scholarship of assessment. San Francisco: Jossey-Bass.

Bennett, M. J. (1993). Towards ethnorelativism: A developmental model of intercultural sensitivity. In R. Paige (Ed.), Education for the intercultural experience (pp. 21-71). Yarmouth, ME: Intercultural Press. 
Bennett, J. M., \& Bennett, M. J. (2004). Developing intercultural sensitivity: An integrative approach to global and domestic diversity. In D. Landis, J. M. Bennett \& M. J. Bennett, Handbook of intercultural training ( $3^{\text {rd }}$ ed., pp. 147-165). Thousand Oaks, CA: Sage.

Bensimon, E. M., Polkinghorne, D. E., Bauman, G. L., \& Vallejo, E. (2004). Doing research that makes a difference. The Journal of Higher Education, 75(1), 104-126.

Bhawuk, D. P. S., \& Sakuda, K. H. (2009). Intercultural sensitivity for global managers. In M. A. Moodian (Ed.), Contemporary leadership and intercultural competence: Exploring crosscultural dynamics within organizations (pp. 255-267). Los Angeles: Sage

Bichelmeyer, B., \& Cagiltay, K. (2000, April). Differences in learning styles in different cultures: A qualitative study. Paper presented at the Annual Meeting of the American Educational Research Association, New Orleans, LA. Retrieved from ERIC database: https://files.eric.ed.gov/fulltext/ED445035.pdf

Bilas, K. (2014, November 14)). International students in higher education: The problems they face and solutions to solve them. Graduate seminar paper, Northeastern University. Retrieved from https://neu.academia.edu/KirstenBilas

Bista, K. (2015). Asian international students' college experience: Relationship between quality of personal contact and gains in learning. Journal of International and Global Studies, 6(2), 38-54.

Bista, K., \& Foster, C. (2011). Issues in international student retention in American higher education. The International Journal of Research and Review, 7(2), 1-10

Bista, K., \& Foster, C. (Eds.). (2016). Exploring the social and academic experiences of international students in higher education institutions. Hershey, PA: Information Science Reference. 
Bista, K., Sharma, G., \& Gaulee, U. (2018). International student mobility: Examining trends and tensions. In K. Bista, (ed.), International student mobility and opportunities for growth in the global market (pp. 1-14). Hershey, PA: IGI Global Publications.

Bona, M., \& Ferrari, L. (2017, November 6). Beyond Erasmus - where and why European students travel. Euobserver. Retrieved from https://euobserver.com/education/139735

Braskamp, L. A. (2009). Internationalizing a campus: A framework for assessing its progress. Journal of College \& Character, 10(7), 1-8.

Bresciani, M. (2009). Evaluating the efficiency, effectiveness and sustainability of outcomesbased program review. The Journal of Faculty Development, 23(1), 30-39.

Briggs, P., \& Ammigan, R. (2017). A collaborative programming and outreach model for international student support offices. Journal of International Students, 7(4), 1080-1095.

Canadian Bureau of International Education [CBIE] (2018, August). International students in Canada. Research brief 10. Retrieved from https://cbie.ca/wpcontent/uploads/2018/09/International-Students-in-Canada-ENG.pdf

Chen, G. M., \& Starosta, W. J. (1996). Intercultural communication competence: A synthesis. Annals of the International Communication Association, 19(1), 353-383.

Chen, D., \& Yang, X. (2014). Striving and thriving in a foreign culture: A mixed method approach on adult international students' experience in USA. Journal of Education and Training Studies, 2(3), 16-25.

Childress, L. K. (2009). Internationalization plans for higher education institutions. Journal of Studies in International Education, 13(3), 289-309.

Choudaha, R. (2016). Campus readiness for supporting international student success. Journal of International Students, 6(4), I-V. 
Choudaha, R. (2017). Three waves of international student mobility (1999-2020). Studies in Higher Education, 42(5), 825-832.

Coates, H. (2007). A model of online and general campus-based student engagement. Assessment \& Evaluation in Higher Education, 32(2), 121-141.

College of Saint Benedict and Saint John's University. (n.d.). 2011-2012 academic catalog. Retrieved on March 28, 2020. https://www.csbsju.edu/academics/2011-2012catalog/academic-departments/academic-skills

Cohen, A. M., \& Brawer, F. B. Kisker (2013). The American community college. (pp. 434)

Creswell, J. W. (2009). Research design: Qualitative, quantitative, and mixed methods approaches ( $3^{\text {rd }}$ ed.). Thousand Oaks, CA: Sage.

Davies, J. (1992). Developing a strategy for internationalization in universities: Towards a conceptual framework. In C. Klasek, B. J. Garavalia, \& K. J. Kellerman (Eds.), Bridges to the future: Strategies for internationalizing higher education (pp. 177-190).

Carbondale, IL: Association of International Education Administrators.

Deardorff, D. K. (2004). In search of intercultural competence. International educator, 13(2), $13-15$.

Deardorff, D. K. (2006). Identification and assessment of intercultural competence as a student outcome of internationalization. Journal of studies in international education, 10(3), 241266.

De Wit, H. (2002). Internationalization of higher education in the United States of America and Europe. Westport, CT: Greenwood Press. 
De Wit. H (2015). Recent trends and issues in international student mobility. International Higher Education, (59). Retrieved from https://ejournals.bc.edu/index.php/ihe/article/view/8481

Di Maria, D. L. (2012). Factors affecting student affairs administrators' views of campus services for international students at five public universities in Ohio. (Doctoral dissertation). Retrieved from ProQuest Dissertations and Theses database. (UMI No. 141666)

Dowd, A. (2007). Community colleges as gateways and gatekeepers: Moving beyond the access" saga" toward outcome equity. Harvard Educational Review, 77(4), 407-419.

Ellingboe, B. J. (1998). Divisional strategies to internationalize a campus portrait: Results, resistance, and recommendations from a case study at a U.S. University. In J. A. Mesternhauser \& B. J. Ellingboe (Eds.), Reforming the higher education curriculum: Internationalizing the campus (pp. 198-338). Phoenix, AZ: American Council on Education and Oryx Press.

Enders, J. (2004). Higher education, internationalisation, and the nation-state: Recent developments and challenges to governance theory. Higher education, 47(3), 361-382.

Ewell, P. (2005, April). Assessing assessment: Successes, failures, and the future [PowerPoint slides]. Presentation at the North Carolina State University Assessment Symposium, Raleigh, NC. Retrieved from https://immagic.com/eLibrary/ARCHIVES/GENERAL/NCHEMSUS/N050414E.pdf

Fabrigar, L. R., Wegener, D. T., MacCallum, R. C., \& Strahan, E. J. (1999). Evaluating the use of exploratory factor analysis in psychological research. Psychological methods, 4(3), 272-299. 
Fantini, A. E. (2000). A central concern: Developing intercultural competence. In A. E. Fantini (Ed.), About our institution (SIT occasional papers series, Issue 1, pp. 25-42). Retrieved from School for International Training Website: https://digitalcollections.sit.edu/cgi/viewcontent.cgi?article $=1000 \&$ context $=$ sop

Gaulee, U., Sharma, S., \& Bista, K . (Eds.). (2020). Rethinking education across borders. Singapore: Springer.

Gebhard, J. G. (2010). What do international students think and feel?: Adapting to U.S. college life and culture. Ann Arbor: University of Michigan Press.

Girmay, M. (2017). Understanding the adjustment needs of international graduate students at Southern Illinois University Carbondale. (Doctoral dissertation). Retrieved from ProQuest Dissertations and Theses database. (Order No. 10636820)

Gluckman, N. (2018, March 4). Loss of global prestige: The United States' appeal as a study abroad destination may be waning. The Chronicle of Higher Education. Retrieved from https://www.chronicle.com/article/More-International-Students/242673

Goode, T. (2002). Promoting cultural and linguistic competency. self-assessment checklist for personnel providing services and supports in early intervention and early childhood settings. Retrieved from Georgetown University web site: https://nccc.georgetown.edu/documents/Checklist.EIEC.doc.pdf

Gopal, A. (2011). Internationalization of higher education: Preparing faculty to teach crossculturally. International Journal of Teaching and Learning in Higher Education, 23(3), $373-381$

Green, M. F. (2012). Measuring and assessing internationalization. Retrieved from NAFSA website: https://shop.nafsa.org/detail.aspx?id=115E. 
Green, M. F., Marmolejo. F. and Egron-Polak. E. (2012). The internationalization of higher education: future prospects. In D. Deardoff, H. de Wit, J. Heyl, \& T. Adams (Eds.), The SAGE handbook of international higher education (pp. 439-453). Thousand Oaks, CA: SAGE.

Grieger, I. (1996). A multicultural organizational development checklist for student affairs. Journal of College Student Development, 37(5), 561-573.

Guo, S. (2015). The changing nature of adult education in the age of migration: Toward a model of recognitive adult education. In S. Guo \& E. Lange (Eds.), Transnational migration, social inclusion, and adult education (New Directions for Adult and Continuing Education, No. 146, pp. 7-17). San Francisco: Jossey-Bass

Guruz, K. (2011). Higher education and international student mobility in the global knowledge economy ( $2^{\text {nd }}$ ed.). Albany: State University of New York Press.

Halic, O., Greenberg, K., \& Paulus, T. (2009). Language and academic identity: A study of the experiences of non-native English speaking international students. International Education, 38(2), 74-94.

Han, X., \& Appelbaum, R. P. (2016). Will they stay or will they go? International STEM students are up for grabs. Retrieved from Ewing Marion Kauffman Foundation web site: https://www.kauffman.org/wp-content/uploads/2019/12/STEM_Students_FINAL.pdf

Harwood, S. A., Choi, S., Orozco Villicaña, M., Huntt, M. B., \& Mendenhall, R. (2015). Racial microaggressions at the University of Illinois at Urbana-Champaign: Voices of students of color in the classroom.

Harwood, N., \& Petrić, B. (2017). Experiencing Master's supervision: Perspectives of international students and their supervisors. New York: Routledge. 
Hayes, R. L., \& Lin, H. (1994). Coming to America: Developing social support systems for international students. Journal of Multicultural Counseling \& Development, 22(1), 7-16.

Hazelkorn, E. (2012). "Everyone wants to be like Harvard" - Or do they? Cherishing all missions equally. In A. Curaj, P. Scott, L. Vlasceanu, \& L. Wilson (Eds.), European higher education at the crossroads: Between the Bologna process and national reforms: Vol. 2. Governance, financing, mission diversification and futures of higher education (pp. 837-862). Dordrecht: Springer.

Hoekje, B. J., \& Stevens, S. G. (2017). Creating a culturally inclusive campus: A guide to supporting international students. New York: Routledge.

Hudzik, J. (2011). Comprehensive internationalization: From concept to action. Washington, DC: NAFSA: Association of International Educators.

Hudzik, J. K. and Stohl, M. (2012). Comprehensive and strategic internationalization of U.S. Higher Education. In D. K. Deardoff, H. de Wit, J. D. Heyl, \& T. Adams (Eds.), The SAGE Handbook of International Higher Education (pp. 61-76). Thousand Oaks, CA: SAGE.

Institute of International Education (2019a). New international student enrollment trends, 2006/07-2018/19 [Data table]. Retrieved from the https://www.iie.org/Research-andInsights/Open-Doors/Data/International-Students/Enrollment

Institute of International Education. (2019b). Project Atlas infographics. Retrieved from https://www.iie.org/Research-and-Insights/Project-Atlas/ExploreData/Infographics/2019-Project-Atlas-Infographics 
Institute of International Education (2020). International student data. Retrieved from https://www.iie.org/Research-and-Insights/Open-Doors/Data/Community-College-DataResource/Community-College---International-Students/Total-Students

Isomine, S. (2015). Interview and assessment: Practice of international student services in higher education. Ōita, Japan: Center for Language Education, Ritsumeikan Asia Pacific University. Retrieved from ERIC database: https://files.eric.ed.gov/fulltext/ED555614.pdf

Jameson, H. P., \& Loper, J. R. (Eds.). (2017). Student affairs professionals cultivating campus climates inclusive of international students (New Directions for Student Services, No. 158). San Francisco: Jossey-Bass.

Jenkins, J. R., \& Galloway, F. (2009). The adjustment problems faced by international and overseas Chinese students studying in Taiwan universities: a comparison of student and faculty/staff perceptions. Asia Pacific Education Review, 10(2), 159-168.

Jennings, R. (2017). International students at community colleges.: challenges and opportunities for this unique segment of U.S. higher education. In H. P. Jameson \& J. R.Loper (Eds.), Student affairs professionals cultivating campus climates inclusive of international students (New Directions for Student Services, No. 158, pp. (61-71). San Francisco: Jossey-Bass.

Kezar, A. J. (2001). Understanding and facilitating organizational change in the 21st century: Recent research and conceptualizations. ASHE-ERIC Higher Education Report, Vol. 28, No. 4). San Francisco, CA: Jossey-Bass.

Kisch, M. (2014). Helping faculty teach international students. International Educator, 23(6), 44-47. 
Knight, J. (1994). Internationalization: Elements and checkpoints (CBIE Research No. 7). Ottawa, ON, Canada: Canadian Bureau for International Education. Retrieved from ERIC database: https://files.eric.ed.gov/fulltext/ED549823.pdf

Knight, J. (1999). Internationalisation of higher education. In J. Knight \& H. de Wit (Eds.), Quality and internationalisation in higher education (pp. 13-28). Paris: OECD.

Knight, J. (2004). Internationalization remodeled: Definition, approaches, and rationales. Journal of Studies in International Education, 8, 5-31.

Knight, J. (2011a). Five myths about internationalization. International Higher Education, 62(Winter), 14-15. Retrieved from https://ejournals.bc.edu/index.php/ihe/article/view/8532

Knight, J. (2011b). Regional education hubs: Mobility for the knowledge economy. In R. Bhandari \& P. Blumenthal (Eds.), International students and global mobility in higher education: National trends and new directions (pp. 211-230). Palgrave Macmillan, New York.

Knight, J. (2012). Student mobility and internationalization: Trends and tribulations. Research in Comparative and International Education, 7(1), 20-33.

Knight, J., \& De Wit, H. (1995). Strategies for internationalisation of higher education: Historical and conceptual perspectives. In H. De Wit (Ed.), Strategies for internationalisation of higher education: A comparative study of Australia, Canada, Europe and the United States of America (pp.10-17). Amsterdam, The Netherlands: EAIE Secretariat. 
Korobova, N., \& Starobin, S. S. (2015). A comparative study of student engagement, satisfaction, and academic success among international and American students. Journal of International Students, 5(1), 72-85.

Koseva, P. (2017). Internationalizing campus partners. Journal of International Students, 7(3), 876-892.

Ku, H. Y., Lahman, M. K., Yeh, H. T., \& Cheng, Y. C. (2008). Into the academy: Preparing and mentoring international doctoral students. Educational Technology Research and Development, 56(3), 365-377.

Kuh, G. (1999). A framework for understanding student affairs work. Journal of College Student Development, 40(5), 530-537.

Kuh, G. (2009). Understanding campus environments. In G. McClellan \& J. Stringer (Eds.), The handbook of student affairs administration (pp. 59-80). San Francisco: Jossey-Bass.

Kuh, G., Kinzie, J., Schuh, J., \& Whitt, E. (2005). Student success in college: Creating conditions that matter. San Francisco: Jossey-Bass.

Lane. J. E., \& Johnstone. D. B. (Eds.). (2011). Higher education systems 3.0: Harnessing systemness, delivering performance. Albany, NY: SUNY Press.

Leask, B. (2009). Using formal and informal curricula to improve interactions between home and international students. Journal of Studies in International Education, 2, 205-221.

Leask, B. (2015). Internationalizing the curriculum. New York: Routledge.

Lee, Y. I., \& Metcalfe, A. S. (2017). Academic advisors and their diverse advisees: Towards more ethical global universities. Journal of International Students, 7(4), 944-962.

Lee Olson, C., \& Kroeger, K. R. (2001). Global competency and intercultural sensitivity. Journal of studies in international education, 5(2), 116-137. 
Lértora, I., Sullivan, J., \& Croffie, A. (2017). They are here, now what do we do?

Recommendations for supporting international student transitions. VISTAS Online.

Retrieved from American Counseling Association website:

https://www.counseling.org/docs/default-source/vistas/supporting-international-studenttransitions.pdf?sfvrsn=669e4a2c_4

Li, J., Wang, Y., Liu, X., Xu, Y., \& Cui, T. (2018). Academic adaptation among international students from East Asian countries: A consensual qualitative research. Journal of International Students, 8(1), 194-214.

Little, B., Locke, W., Scesa, A., \& Williams, R. (2009). Report to HEFCE on student engagement. Retrieved from the Open University web site: http://oro.open.ac.uk/15281/1/Report_to_HEFCE_on_student_engagement.pdf

Marginson, S. (2011). Imagining the global. In King, R., Marginson, S., \& Naidoo, R. (Eds.). (2011). Handbook on globalization and higher education (pp. 10-36). Cheltenham, United Kingdom: Edward Elgar Publishing.

Matveev, A. V., \& Milter, R. G. (2004). The value of intercultural competence for performance of multicultural teams. Team Performance Management: An International Journal, 10(56), 104-111.

Mayo, S., \& Larke, P. J. (2011). Multicultural education transformation in higher education: Getting faculty to" buy in." Journal of Case Studies in Education, 1. Retrieved from ERIC database: https://files.eric.ed.gov/fulltext/EJ1055514.pdf

McArthur, R. C. (2002). Democratic leadership and faculty empowerment at the community college: A theoretical model for the department chair. Community College Review, 30(3), $1-10$. 
McFarlane, A. M. (2015). Internationalisation and the role for student affairs professionals:

Lessons learned from the International Student Engagement Meeting Initiative. Journal of Student Affairs in Africa, 3(1), 83-91.

Mestenhauser, J. (2006). Internationalization at Home: Systems challenge to a fragmented field. In H. Teekens (Ed.), Internationalization at Home: A global perspective (pp. 61-78). The Hague, The Netherlands: NUFFIC: The Dutch Organisation for Internationalisation in Education.

McTaggart, R. (1989). 16 tenets of participatory action research. Retrieved from http://www.caledonia.org.uk/par.htm

Michigan State University (n.d.). International students. Retrieved from https://careernetwork.msu.edu/resources-tools/student-resources/resources-forinternational-students.html

Mori, S. C. (2000). Addressing the mental health concerns of international students. Journal of Counseling \& Development, 78(2), 137-144.

Morley, M. J., \& Cerdin, J. L. (2010). Intercultural competence in the international business arena. Journal of Managerial Psychology, 25(8), 805-809.

National Association of Foreign Student Advisers [NAFSA]. (2018, November 13). International Students Contribute \$39 Billion to the U.S. Economy. Retrieved from https://www.nafsa.org/about/about-nafsa/new-nafsa-data-international-studentscontribute-39-billion-us-economy

National Association of Foreign Student Advisers [NAFSA]. (2018). Trends in US study abroad. Retrieved from https://www.nafsa.org/policy-and-advocacy/policy-resources/trends-usstudy-abroad 
National Association of Foreign Student Advisers [NAFSA]. (2019a). Leading internationalization. Retrieved from https://www.nafsa.org/professionalresources/browse-by-interest/leading-internationalization

National Association of Foreign Student Advisers [NAFSA] (2019b). Losing talent. An economic and foreign policy risk America can't ignore. Retrieved from https://www.nafsa.org/sites/default/files/media/document/nafsa-losing-talent.pdf

National Center for Education Statistics [NCES] (2018). Total fall enrollment in degree-granting postsecondary institutions, by level and control of institution and race/ethnicity or nonresident alien status of student: Selected years, 1976 through 2017. (detailed statistical tables, NCES 306.2). Retrieved from https://nces.ed.gov/programs/digest/d18/tables/dt18_306.20.asp

National Science Foundation, National Center for Science and Engineering Statistics. (2015) Science and engineering degrees: 1966-2012 (Detailed statistical tables, NSF 15-326). Retrieved from http://www.nsf.gov/statistics/2015/nsf15326/

Nguyen, D. J., \& Larson, J. B. (2017). Exploring the influence of student affairs on adjustment and adaptation for Indonesian graduate students. Journal of International Students, 7(4), 1010-1029.

Nielsen, S. Y. (2011). The perceptions of globalization at a public research university computer science graduate department. (Doctoral dissertation). Retrieved from ProQuest Dissertations and Theses database. (UMI No. 883516446)

Nilsson, P. A., \& Ripmeester, N. (2016). International student expectations: Career opportunities and employability. Journal of International Students, 6(2), 614-631. 
Northern Arizona University (2020). Academic catalog. Retrieved from http://catalog.nau.edu/Courses/course?courseId=010979\&term=1211

Olivas, M., \& Li, C. S. (2006). Understanding stressors of international students in higher education: What college counselors and personnel need to know. Journal of Instructional Psychology, 33(3), 217-222.

Olson, C., \& Peacock, J. (2012). Globalism and interculturalism: Where global and local meet. In D. K Deardorff, H. de Wit, J. D. Heyl, \& T. Adams (Eds.), The Handbook of International Higher Education (pp. 305-322). Los Angeles: Sage, 305-322.

Onyenekwu, I. U. (2017). Providing culturally relevant services for international Black African collegians in the United States: A guide for student affairs professionals. Journal of International Students, 7(4), 1113-1125.

Osfield, K. (2008). Internationalization of student affairs and services: An emerging global perspective. Washington, DC: NASPA.

Özturgut, O. (2013). Best practices in recruiting and retaining international students in the US. Current Issues in Education, 16(2), 1-22. Retrieved from https://cie.asu.edu/ojs/index.php/cieatasu/article/view/1213/495

Özturgut, O., \& Murphy, C. (2009). Literature vs. practice: Challenges for international students in the U.S. International Journal of Teaching and Learning in Higher Education, 22(3), $374-385$.

Pace, C. Robert. (1984). Measuring the quality of college student experiences. An account of the development and use of the College Student Experiences Questionnaire. Los Angeles: Higher Education Research Institute. Retrieved from ERIC database: https://eric.ed.gov/?id=ED255099. 
Pacheco. E. (2020). International student well-being and the influence of politics. In U. Gaulee, S. Sharma, \& K. Bista, (Eds.), Rethinking Education Across Borders (pp. 193-207). Singapore: Springer.

Paige, R. M. (2005). Internationalization of higher education: Performance assessment and indicators. Nagoya Journal of Higher Education, 5(8), 99-122.

Paige, R. M., Cohen, A. D., \& Shively, R. L. (2004). Assessing the Impact of a Strategies-Based Curriculum on Language and Culture Learning Abroad. Frontiers: The interdisciplinary journal of study abroad, 10, 253-276.

Paige, R. M., \& Mestenhauser, J. A. (1999). Internationalizing educational administration. Educational Administration Quarterly, 35(4), 500-517.

Palomba, C. A., \& Banta, T. W. (1999). Assessment essentials: Planning, implementing, and improving assessment in higher education ( $1^{\text {st }}$ ed.). San Francisco: Jossey-Bass.

Palomba, C. A., \& Banta, T. W. (2014). Assessment essentials: Planning, implementing, and improving assessment in higher education (2 ${ }^{\text {nd }}$ ed.). San Francisco: Jossey-Bass.

Pascarella, E. T., \& Terenzini, P. T. (2005). How college affects students: Vol. 2. A third decade of research. San Francisco: Jossey-Bass.

Paton, M. J. (2007). Why international students are at greater risk of failure: An inconvenient truth. International Journal of Diversity in Organisations, Communities \& Nations, 6(6), $101-111$

Perez-Encinas, A., \& Ammigan, R. (2016). Support services at Spanish and US institutions: A driver for international student satisfaction. Journal of International students, 6(4), 984998. 
Polyak, I., Kéry, D., \& Tardos, K. (2013). Enhancing intercultural competence of university faculty. Retrieved from SSRN website: https://papers.ssrn.com/sol3/papers.cfm?abstract_id=2351881

Pope, R. (1993). Multicultural-organization development in student affairs: An introduction. Journal of College Student Development, 34(3), 201-205.

Pope, R., \& Reynolds, A. (1997). Student affairs core competencies: Integrating multicultural awareness, knowledge, and skills. Journal of College Student Development, 38(3), 266277.

Poyrazli, S., \& Grahame, K. M. (2007). Barriers to adjustment: Needs of international students within a semi-urban campus community. Journal of instructional Psychology, 34(1), 28.

Qiang, Z. (2003). Internationalization of higher education: Towards a conceptual framework. Policy futures in education, 1(2), 248-270.

QS Quacquarelli Symonds (2017). QS world university rankings by subject 2017. Retrieved from https://www.qs.com/qs-world-university-rankings-subject-2017/

Raby, L. R, \& Zhang, Y. (Leaf). (2020). Changing theoretical perspectives on transnational mobility: A review of the literature. In U. Gaulee, S. Sharma, \& K. Bista, (Eds.), Rethinking Education Across Borders (pp. 19-46). Singapore: Springer.

Redden, E. (2018, November 13). New international enrollments decline again. Inside Higher $E d$. Retrieved from https://www.insidehighered.com/news/2018/11/13/new-internationalstudent-enrollments-continue-decline-us-universities 
Roy, M., Lu, Z., \& Loo, B. (2016). Improving the international student experience: Implications for recruitment and support (Report 08). Retrieved from World Education Services web site: https://knowledge.wes.org/WES-Research-Report-Improving-Intl-StudentExperience.html.

Rumbley, L., Altbach,P., \& Reisberg, L. (2012). Internationalization within the higher education context. In D. Deardoff, H. de Wit, J. Heyl, \& T. Adams (Eds.), The SAGE handbook of international higher education (pp. 3-26). Thousand Oaks, CA: Sage.

Salmi, J. (2009). The challenge of establishing world-class universities. Retrieved from World Bank Group web site: https://openknowledge.worldbank.org/handle/10986/2600?localeattribute $=$ en.

Schinke, R. J., da Costa, J., \& Andrews, M. (2001). Considerations regarding graduate student persistence. Alberta journal of educational research, 47(4), 341-352.

Schulmann, P. (2017, March 7). African student mobility: Regional trends and recommendations for U.S. HEIs. World Education News and Reviews. Retrieved from https://wenr.wes.org/2017/03/african-student-mobility-insights-and-recommendation-foru-s-heis

Search results for: "Regional Hub." (2020). Retrieved from ICEF Monitor web site: http://monitor.icef.com/?s=regional+hub\&submit=Search

Senge, P. (2006). The fifth discipline: The art and practice of the learning organization. New York, NY: Doubleday.

Sherry, M., Thomas, P., \& Chui, W. H. (2010). International students: A vulnerable student population. Higher Education 60(1), 33-46. 
Smith, L. R. (1999). Intercultural network theory: A cross-paradigmatic approach to acculturation. International Journal of Intercultural Relations, 23(4), 629-658.

Smith, C. (2020). International students and their academic experiences: student satisfaction, student success challenges, and promising teaching practices. In U. Gaulee, S. Sharma, \& K. Bista, (Eds.), Rethinking Education Across Borders (pp. 271-287). Singapore: Springer.

Soria, K. M., \& Troisi, J. (2014). Internationalization at home alternatives to study abroad: Implications for students' development of global, international, and intercultural competencies. Journal of Studies in International Education, 18(3), 261-280.

Spencer, L. A. M. (2016). Exploring the transition experiences of successful international undergraduate students at a public research university in the USA: The impact on international student success and retention. (Doctoral dissertation). Retrieved from ProQuest Dissertations and Theses database. (Order No. 10144719)

Stella, A., \& Liston, C. (2007). Internationalisation of Australian universities: Learning from cycle 1 audits. Australian Universities Quality Agency.

Stier, J. (2003). Internationalisation, ethnic diversity and the acquisition of intercultural competencies. Intercultural Education, 14(1), 77-92.

Sujitparapitaya, S. (2014). Achieving faculty buy-in: Motivation performance in learning outcome assessment. Journal of Case Studies in Accreditation and Assessment, 3. Retrieved from ERIC database: https://files.eric.ed.gov/fulltext/EJ1060582.pdf

Talbot, D. (2003). Multiculturalism. In S. Komives \& D. Woodard (Eds.), Student services: $A$ handbook for the profession, 423-446. San Francisco: Jossey-Bass. 
The Center for Global Education. (2014). Innovative international student support programming. Retrieved from http://globaled.us/internationalization/orientation-courses.asp

Thelin, J. R. (2004). A history of American higher education. Baltimore, MD: Johns Hopkins University Press.

Tinto, V. (1993). Leaving college: Rethinking the causes and cures of student attrition ( $2^{\text {nd }}$ ed.). Chicago, IL. University of Chicago Press.

Tolman, S. (2017). The effects of a roommate-pairing program on international student satisfaction and academic success. Journal of International Students, 7(3), 522-541.

Trice, A. G. (2000, May). Navigating in a global learning community: Academic departments' response to graduate international students. Paper presented at the AIR 2000 Annual Forum, Cincinnati, OH. Retrieved from ERIC database: https://files.eric.ed.gov/fulltext/ED445645.pdf

Trice, A. G. (2003). Faculty perceptions of graduate international students: The benefits and challenges. Journal of Studies in International Education, 7(4), 379-403.

UNESCO (2015). Facts and figures: Mobility in higher education. Retrieved from https://en.unesco.org/node/252278

UNESCO (2017). Migration data portal. Retrieved from https://migrationdataportal.org/themes/international-students University of California and Los Angeles. (2020). UCLA general catalog 2019-20. Retrieved from http://catalog.registrar.ucla.edu/ucla-catalog19-20-1381.html

U.S. Bureau of Labor Statistics. (September 4, 2019). Employment in STEM occupations. 20182028 (Detailed statistical tables). Retrieved from https://www.bls.gov/emp/tables/stememployment.htm 
Warwick, P., \& Moogan, Y. J. (2013). A comparative study of perceptions of internationalisation strategies in UK universities. Compare: A Journal of Comparative and International Education, 43(1), 102-123.

Willer, P. (1992). Student Affairs Professionals as International Educators: A Challenge for the Next Century. In D. McIntire \& P. Willer (Eds.), Working with international students and scholars on American campuses (pp.161-167). Washington, DC: National Association of Student Personnel Administrators. Retrieved from ERIC database: https://files.eric.ed.gov/fulltext/ED360599.pdf

Yang, R. (2002). University internationalisation: Its meanings, rationales and implications. Intercultural Education, 13(1), 81-96.

Yeh, C. J., \& Inose, M. (2003). International students' reported English fluency, social support satisfaction, and social connectedness as predictors of acculturative stress. Counselling Psychology Quarterly, 16(1), 15-28.

Zhai, L. (2002). Studying international students: Adjustment issues and social support (Unpublished manuscript). Retrieved from ERIC database: https://files.eric.ed.gov/fulltext/ED474481.pdf.

Zhao, C. M., Kuh, G. D., \& Carini, R. M. (2005). A comparison of international student and American student engagement in effective educational practices. The Journal of Higher Education, 76(2), 209-231.

Zhao, J. and Ng, F. D. (2016). Understanding language experiences of international ESL students in U.S. classrooms. In K. Bista \& C. Foster (Eds.), Exploring the social and academic experiences of international students in higher education institutions (pp. 175-196). Hershey, PA: Information Science Reference. 
Please indicate the extent to which you agree or disagree with each of the following statements.

\begin{tabular}{|c|c|c|c|c|c|c|}
\hline & Survey Question & $\begin{array}{l}\text { Strongly } \\
\text { Disagree }\end{array}$ & Disagree & Agree & $\begin{array}{c}\text { Strongly } \\
\text { Agree }\end{array}$ & $\begin{array}{l}\text { Don't } \\
\text { Know }\end{array}$ \\
\hline $1 \mathrm{a}$ & $\begin{array}{l}\text { My institution surveys international students on a regular basis to } \\
\text { understand their preferences for receiving information (e.g., e-mail, face- } \\
\text { to-face, social media, etc.) }\end{array}$ & & & & & \\
\hline $1 \mathrm{~b}$ & $\begin{array}{l}\text { My institution should survey international students on a regular basis to } \\
\text { understand their preferences for receiving information (e.g., e-mail, face- } \\
\text { to-face, social media, etc.) }\end{array}$ & & & & & \\
\hline $2 \mathrm{a}$ & $\begin{array}{l}\text { My institution surveys international students on a regular basis to } \\
\text { understand how frequently they would prefer to receive information } \\
\text { from their institutions. }\end{array}$ & & & & & \\
\hline $2 b$ & $\begin{array}{l}\text { My institution should survey international students on a regular basis to } \\
\text { understand how frequently they would prefer to receive information } \\
\text { from their institutions. }\end{array}$ & & & & & \\
\hline $3 a$ & $\begin{array}{l}\text { My institution surveys international students on a regular basis to } \\
\text { understand the types of information that will be most helpful to them. }\end{array}$ & & & & & \\
\hline $3 b$ & $\begin{array}{l}\text { My institution should survey international students on a regular basis to } \\
\text { understand the types of information that will be most helpful to them. }\end{array}$ & & & & & \\
\hline $4 \mathrm{a}$ & $\begin{array}{l}\text { My institution assesses the extent to which international students are } \\
\text { satisfied with campus support services. }\end{array}$ & & & & & \\
\hline $4 b$ & $\begin{array}{l}\text { My institution should assess the extent to which international students } \\
\text { are satisfied with campus support services. }\end{array}$ & & & & & \\
\hline $5 a$ & $\begin{array}{l}\text { My institution provides career services that help international students } \\
\text { find on-campus, part-time jobs }\end{array}$ & & & & & \\
\hline $5 b$ & $\begin{array}{l}\text { My institution should provide career services that help international } \\
\text { students find on-campus, part-time jobs }\end{array}$ & & & & & \\
\hline
\end{tabular}




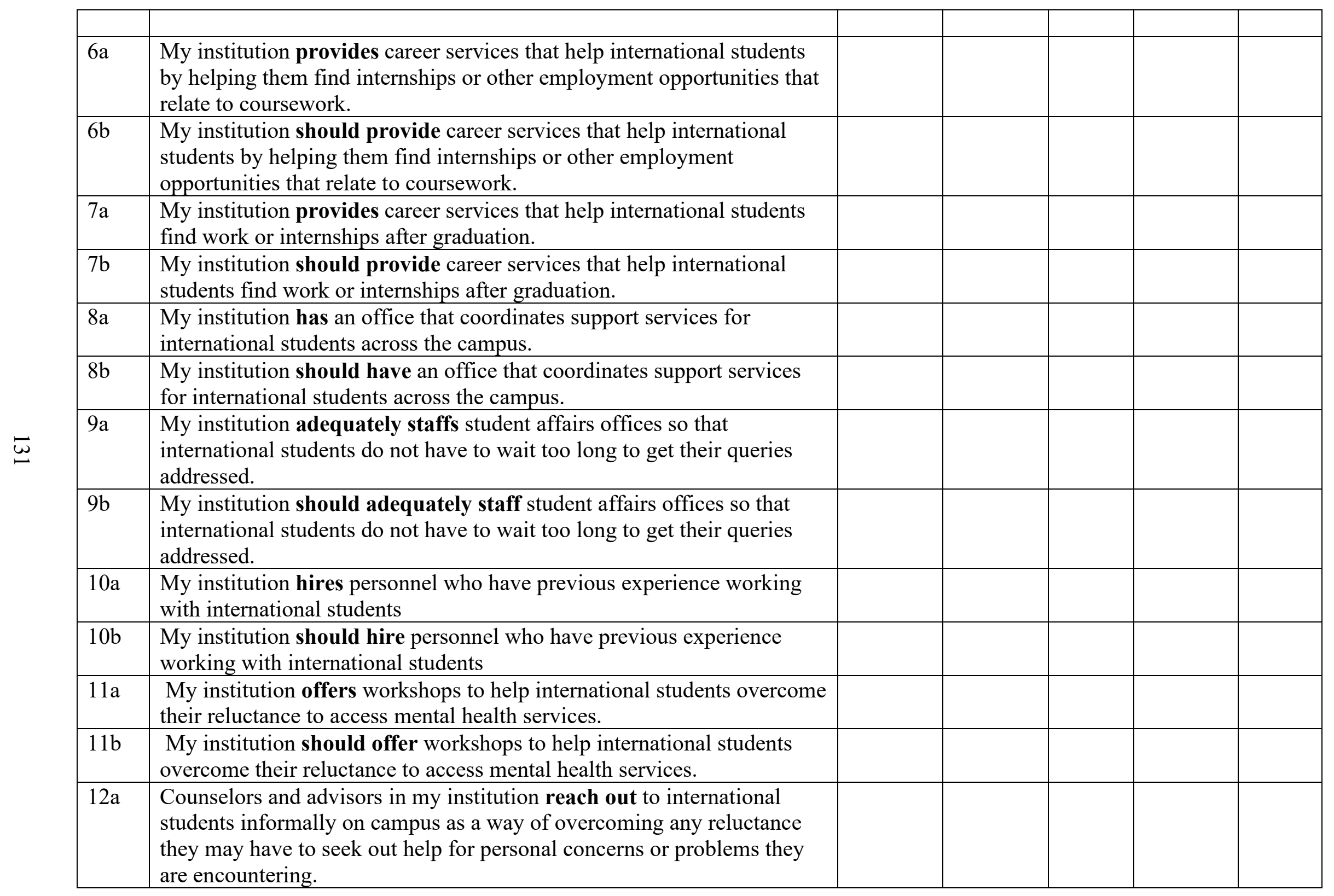




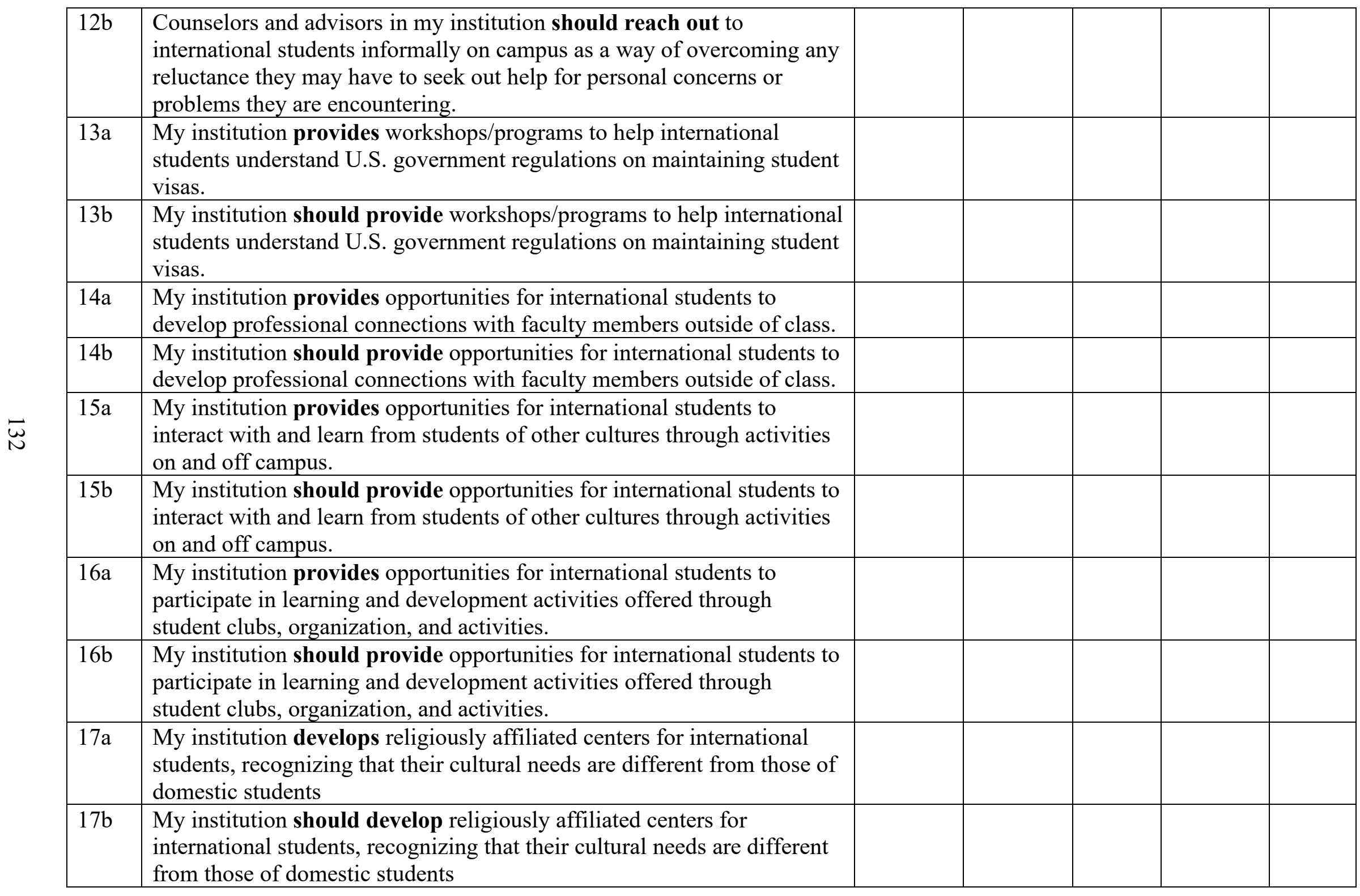




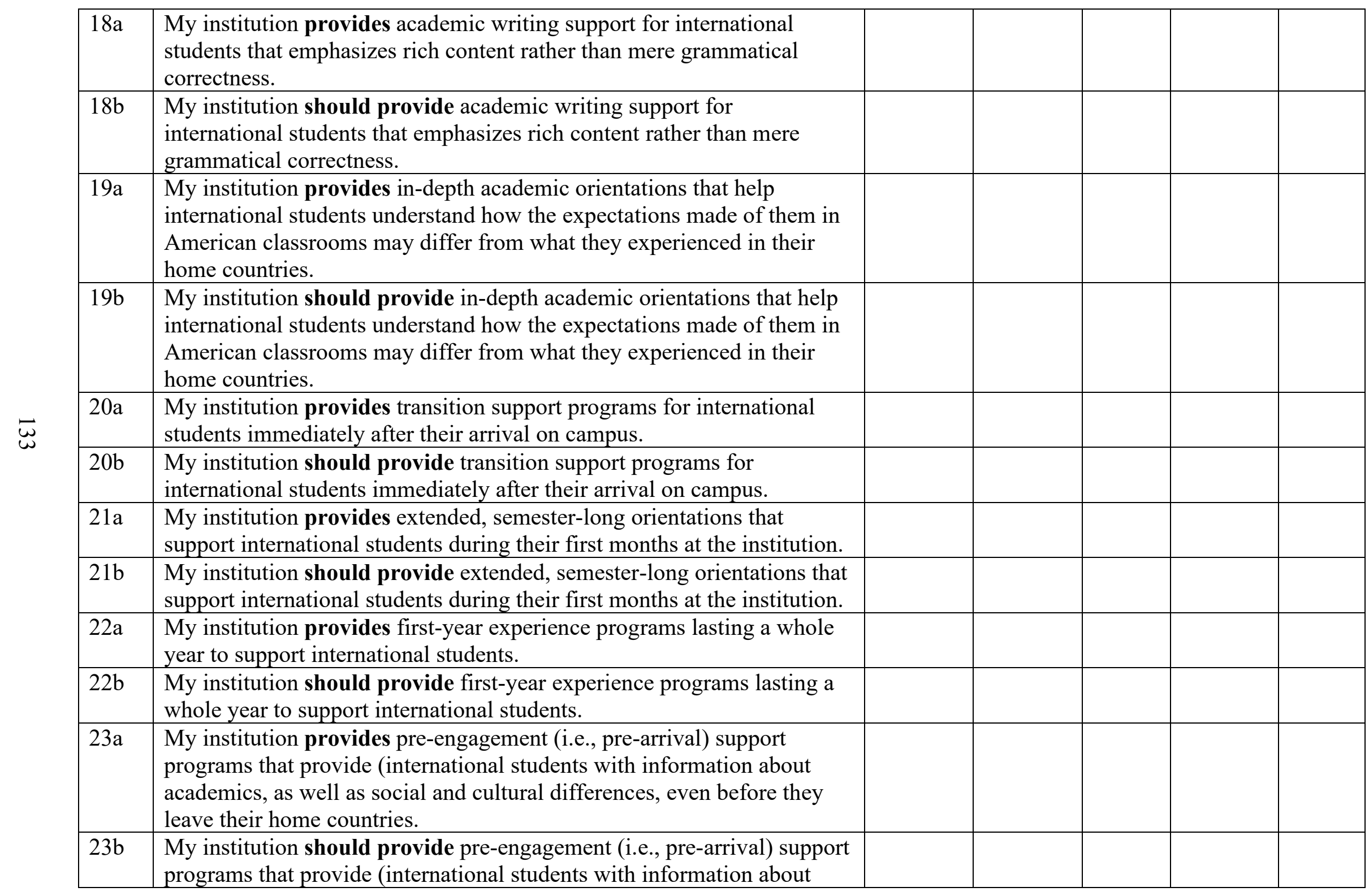




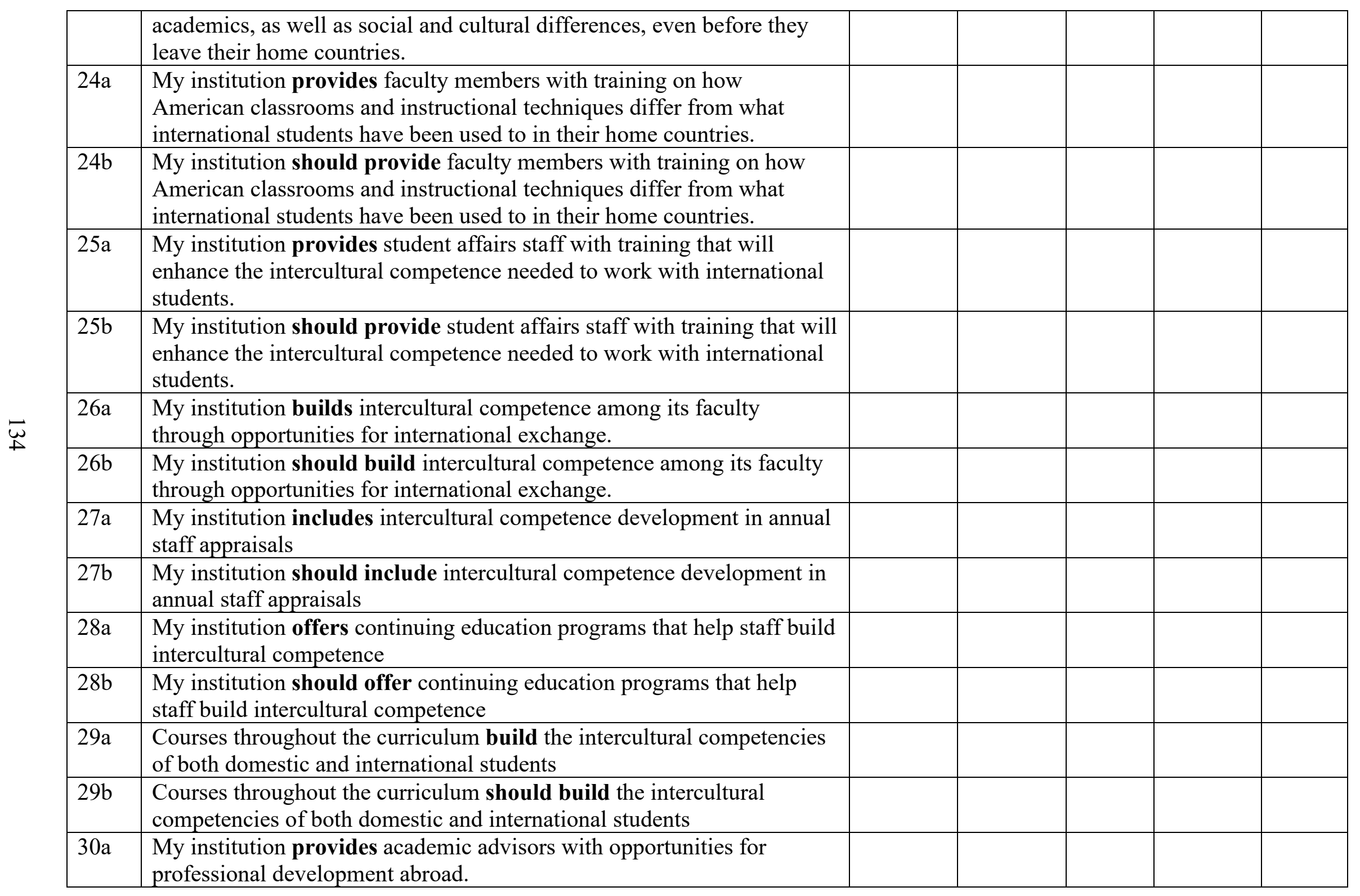




\begin{tabular}{|l|l|l|l|l|}
\hline $30 \mathrm{~b}$ & $\begin{array}{l}\text { My institution should provide academic advisors with opportunities for } \\
\text { professional development abroad. }\end{array}$ & & & \\
\hline $31 \mathrm{a}$ & $\begin{array}{l}\text { My institution provides certificate courses on various aspects of } \\
\text { intercultural competence (e.g., communication, empathy, cultural } \\
\text { considerations etc.) for international student services (ISS) staff }\end{array}$ & $\begin{array}{l}\text { My institution should provide certificate courses on various aspects of } \\
\text { intercultural competence (e.g., communication, empathy, cultural } \\
\text { considerations etc.) for international student services (ISS) staff }\end{array}$ & & \\
\hline $31 \mathrm{~b}$ & & & \\
\hline
\end{tabular}

\section{Background:}

1. Where is your institution located? Select State

2. Which of the following best describes your institution?

a. We are a four-year public college/university

b.We are a four-year private non-profit college or university

c. We are a four-year private for-profit college or university

3. Which department/ Unit are you a part of ?:

4. Which of the following best describes the primary function of your unit?

○ To provide a campus support service such as book stores, food services, parking, mail services and transportation.

$\circ$ To provide services that support the instructional mission and assist students to overcome a variety of academic challenges.

$\circ$ To provide immigration, SEVIS services to international students

$\circ$ To provide programs, services or activities that focus on developing students holistically

$\circ$ Other

5. How many students enrolled in your institution during the last academic year (fall 2018 to Spring 2019)?

6. Do you see the following as a challenge to your institution's international student recruitment?

o International competition

- Internal policies and practices at your institution

$\circ$ Lack of institutional internationalization strategy

$\circ$ Managing partnerships with education agencies

$\circ$ Managing partnerships with other agencies (non-education)

$\circ$ Visa challenges 


\section{o Recruitment budget}

7. In your opinion, on a scale of 1-10, how do you rate your institutions' international student services?

8. In your opinion, how much of a priority is international student services for your institution?

a. Higher priority than domestic student services

b. Equal priority to domestic student services

c. Lower priority to domestic student services

9.Does your institution have an International Student Services or Scholars Office?

$\circ$ Yes

o No

10. Does your institution have an International Student Affairs Department?

○ Yes

○ No

11. Please list some of the unique services your department provides to international students.

12. What are the major challenges you have experienced while serving international students?

13. What barriers, do you reckon, are obstructing comprehensive international student services at your institution?

\section{Thank you for your time!}




\section{APPENDIX B: MODIFIED QUESTIONNAIRE FOR PILOT STUDY}

Q1 Where is your institution located?

Q2 Which of the following best describes your institution?

a. We are a four-year public college/university

b. We are a four-year private non-profit college or university

c. We are a four-year private for-profit college or university

Q3 Which of the following best describes the primary function of your unit?

b. International students and scholar's office- To provide services that support and assist international students to overcome a variety of challenges.

c. Admissions and Enrollment Office

d. Student affairs- To provide a campus support service such as housing, bookstores, food services, parking, mail services, and transportation.

e. Academic department

f. English language institute- To provide language assistance for international students.

g. Office of global partnerships, study abroad programs

h. Office of Diversity and Inclusion/Multicultural Centre- To provide community engagement through student organizations

i. Other

Q4. Does your institution have an International Student or Scholars Office/Department?

- Yes

- No

Q5. Does your institution have an Office/ Department within the student affairs division that is devoted to international students?

- Yes

- No

Q6. About how many international students were enrolled in your institution during the last academic year (fall 2018)?

- $1-50$

- 51-100

- 101-250

- 251-499 
- $500-750$

- 751-999

- $1000-2000$

- 2001-4999

- $>5000$

Q7. Do you see any of the following as a challenge to your institution's international student recruitment? (Check all that apply)

- a. International competition

- b. Internal policies and practices at your institution

- c. Lack of institutional internationalization strategy

- d. Managing partnerships with education agencies

- e. Managing partnerships with other agencies (non-education)

- $\quad$ f. Visa challenges

- $\quad$ g. Recruitment budget

- h. Other

Q8. In your opinion, how much of a priority is international student services for your institution?

- a. Higher priority than domestic student services

- b. Equal priority to domestic student services

- c. Lower priority to domestic student services

- d. No Priority

- e. No Opinion

Q9. Please indicate 'using the drop boxes for each question below' the extent to which you agree or disagree with each of the following statements. The drop box will give you 5 options: Strongly Agree, Agree, Disagree, Strongly Agree and Don't Know

International Student: "an individual who has physically crossed an international border between two countries with the objective to participate in educational activities in a destination country, where the destination country is different from his or her country of origin." (UNESCO, 2015)

Campus Services for International Students: For the purpose of this study, campus services for international students are defined as any unique service or adaptation of a general service provided by the institution and existing primarily to meet the needs of international students. 
Institution: For the purpose of this study, an institution refers to the whole degree-granting organization comprised of several colleges, departments, and units.

Department / Unit - A division of a school or college focused in a particular academic area - reports to a unit other than another department, usually a college. Example- International student office, Student affairs department, career services department, etc.

1a. My institution surveys international students on a regular basis to understand their preferences for communication or receiving information (e.g., e-mail, face-to-face, social media, etc.)

1b. My institution should survey international students on a regular basis to understand their preferences for communication or receiving information (e.g., e-mail, face-to-face, social media, etc.)

2a.My institution surveys international students on a regular basis to understand how frequently they would prefer to receive communication or information from their institutions.

2b. My institution should survey international students on a regular basis to understand how frequently they would prefer to receive communication information from their institutions.

3a. My institution surveys international students on a regular basis to understand the types of information or communication that will be most helpful to them.

3b. My institution should survey international students on a regular basis to understand the types of information or communication that will be most helpful to them.

4a. My institution assesses or evaluates the extent to which international students are satisfied with campus support services.

4b. My institution should assess or evaluate the extent to which international students are satisfied with campus support services.

5a. My institution has an office that coordinates support services for international students across the campus.

5b. My institution should have an office that coordinates support services for international students across the campus.

6a. My institution adequately staffs international student offices or international student affairs units so that international students do not have to wait too long to get their queries addressed.

6b. My institution should adequately staff international student offices or international student affairs units so that international students do not have to wait too long to get their queries addressed.

7a. My institution hires personnel in international student offices or international student affairs units who have previous experience working with international students 
7b. My institution should hire personnel in international student offices or international student affairs units who have previous experience working with international students

8a. My institution helps international students find on-campus, part-time assistantships

8b. My institution should help international students find on-campus part-time assistantships

9a. My institution helps international students find internships or training opportunities that relate to coursework.

9b. My institution should help international students find internships or training opportunities that relate to coursework.

10a. My institution provides career services that help international students find work or internships after graduation

10b. My institution should provide career services that help international students find work or internships after graduation.

11a. My institution offers workshops or programs to help international students overcome any reluctance they might have to access mental health services.

11b. My institution should offer workshops or programs to help international students overcome any reluctance they might have to $\vec{D}$ access mental health services.

12a. My institution provides workshops or programs to help international students understand U.S. government regulations on maintaining student visas.

12b. My institution should provide workshops or programs to help international students understand U.S. government regulations on maintaining student visas.

13a. My institution provides opportunities for international students to interact with faculty members outside of class.

13b. My institution should provide opportunities for international students to interact with faculty members outside of class.

14a. My institution provides opportunities for international students to interact with and learn from students of other cultures through activities on and off campus.

14b. My institution should provide opportunities for international students to interact with and learn from students of other cultures through activities on and off campus.

15a. My institution provides opportunities for international students to further their learning and development through participation in student clubs, organizations, and other campus activities.

15b. My institution should provide opportunities for international students to further their learning and development through participation in student clubs, organizations, and other campus activities 
16a. My institution develops religiously affiliated centers for international students, recognizing that their cultural needs may be different from those of domestic students

16b. My institution should develop religiously affiliated centers for international students, recognizing that their cultural needs may be different from those of domestic students

17a. My institution provides writing support for international students that goes beyond mere grammatical correctness and emphasizes disciplinary content and context.

17b. My institution should provide writing support for international students that goes beyond mere grammatical correctness and emphasizes disciplinary content and context.

18a. My institution provides pre-engagement (i.e., pre-arrival) information programs for international students on academics, social and cultural differences in the U.S., even before they leave their home countries.

18b. My institution should provide pre-engagement (i.e., pre-arrival) information programs for international students on academics, social and cultural differences in the U.S., even before they leave their home countries.

19a. My institution provides in-depth on-campus academic orientations that help international students understand how American classrooms may differ from what they experienced in their home countries.

19b. My institution should provide in-depth on-campus academic orientations that help international students understand how American classrooms may differ from what they experienced in their home countries.

20a. My institution provides extended, semester-long orientations that support international students during their first months at the institution.

20b. My institution should provide extended, semester-long orientations that support international students during their first months at the institution.

21a. My institution provides faculty members with training on how American classrooms and instructional techniques differ from what international students have been used to in their home countries.

21b. My institution should provide faculty members with training on how American classrooms and instructional techniques differ from what international students have been used to in their home countries.

22a. My institution provides training in intercultural competence for all staff who work with international students

22b. My institution should provide training in intercultural competence for all staff who work with international students

23a. My institution includes intercultural competence as a criterion in the appraisals of staff who work with international students. 
23b. My institution should include intercultural competence as a criterion in the appraisals of staff who work with international students.

24a. My institution builds intercultural competence among its faculty through opportunities for international exchange.

24b. My institution should build intercultural competence among its faculty through opportunities for international exchange.

25a. My institution provides academic advisors with opportunities for professional development abroad that help develop intercultural competence.

25b. My institution should provide academic advisors with opportunities for professional development abroad that help develop intercultural competence.

26a. My institution provides certificate courses on various aspects of intercultural competence (e.g., communication, empathy, cultural considerations, etc.) for international student services (ISS) staff.

26b. My institution should provide certificate courses on various aspects of intercultural competence (e.g., communication, empathy, cultural considerations, etc.) for international student services (ISS) staff.

27a. My institution offers courses throughout the curriculum to build the intercultural competencies of both domestic and international students.

27b. My institution should offer courses throughout the curriculum to build the intercultural competencies of both domestic and international students.

Q10. Are there other services your institution/department provides to international students?

Q11. What are the major challenges you have experienced while serving international students? 


\section{APPENDIX C: SURVEY INSTRUMENT}

Q1. Which of the following best describes your institution?

a. We are a four-year public college/university

b. We are a four-year private non-profit college or university

c. We are a four-year private for-profit college or university

Q2. About how many international students were enrolled in your institution during the last academic year (fall 2018)?

$1-50$

$51-100$

$101-250$

$251-499$

$500-750$

751-999

$1000-2000$

2001-4999

$>5000$ 
Q3. This section provides a list of statements concerning various types of international student services. You will be asked to rate (on 1-5 scales) your agreement to which the statement DOES reflect actual practice in your institution on the left and to the which the statements SHOULD reflect practice in your institutions.

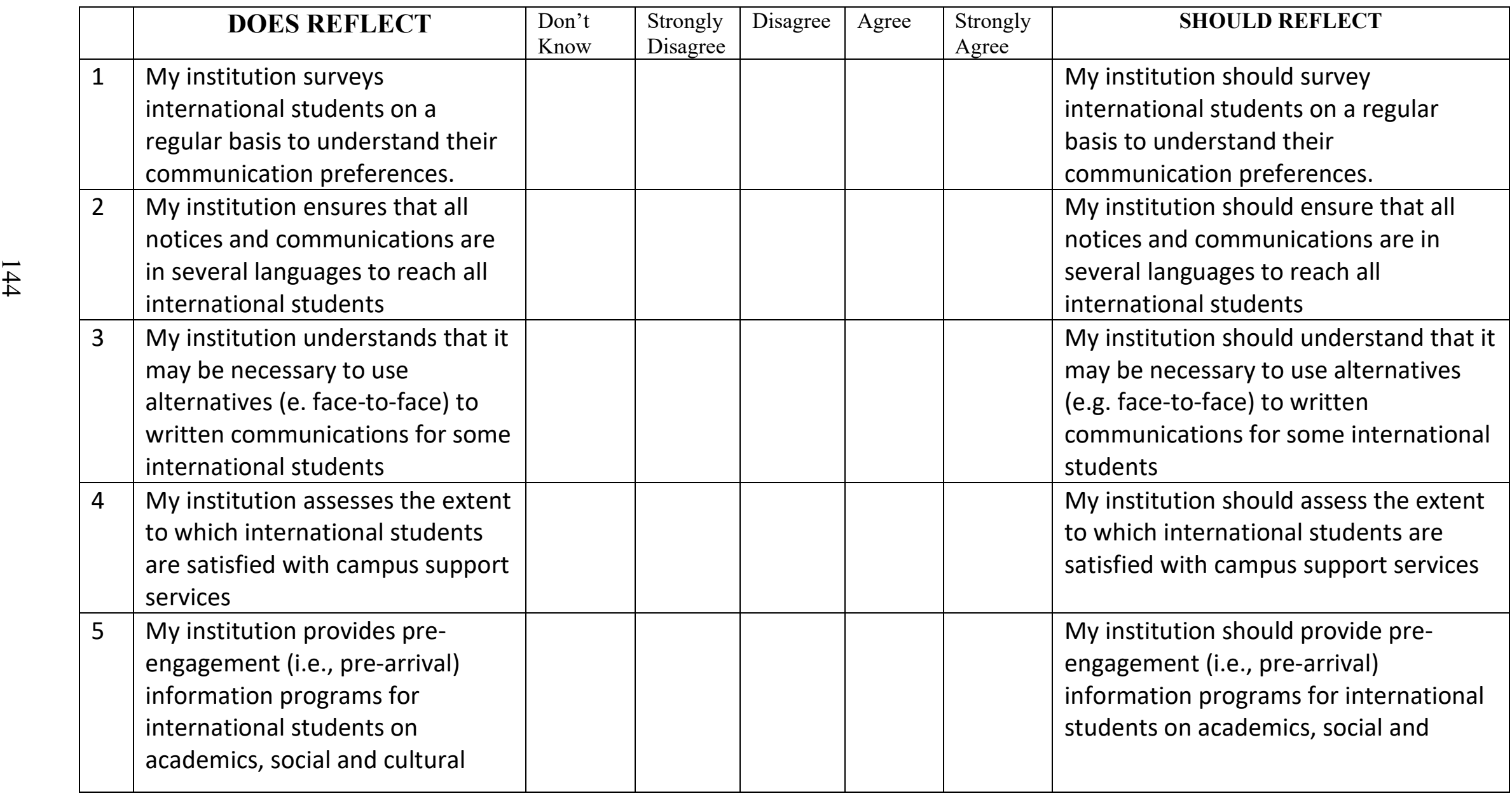




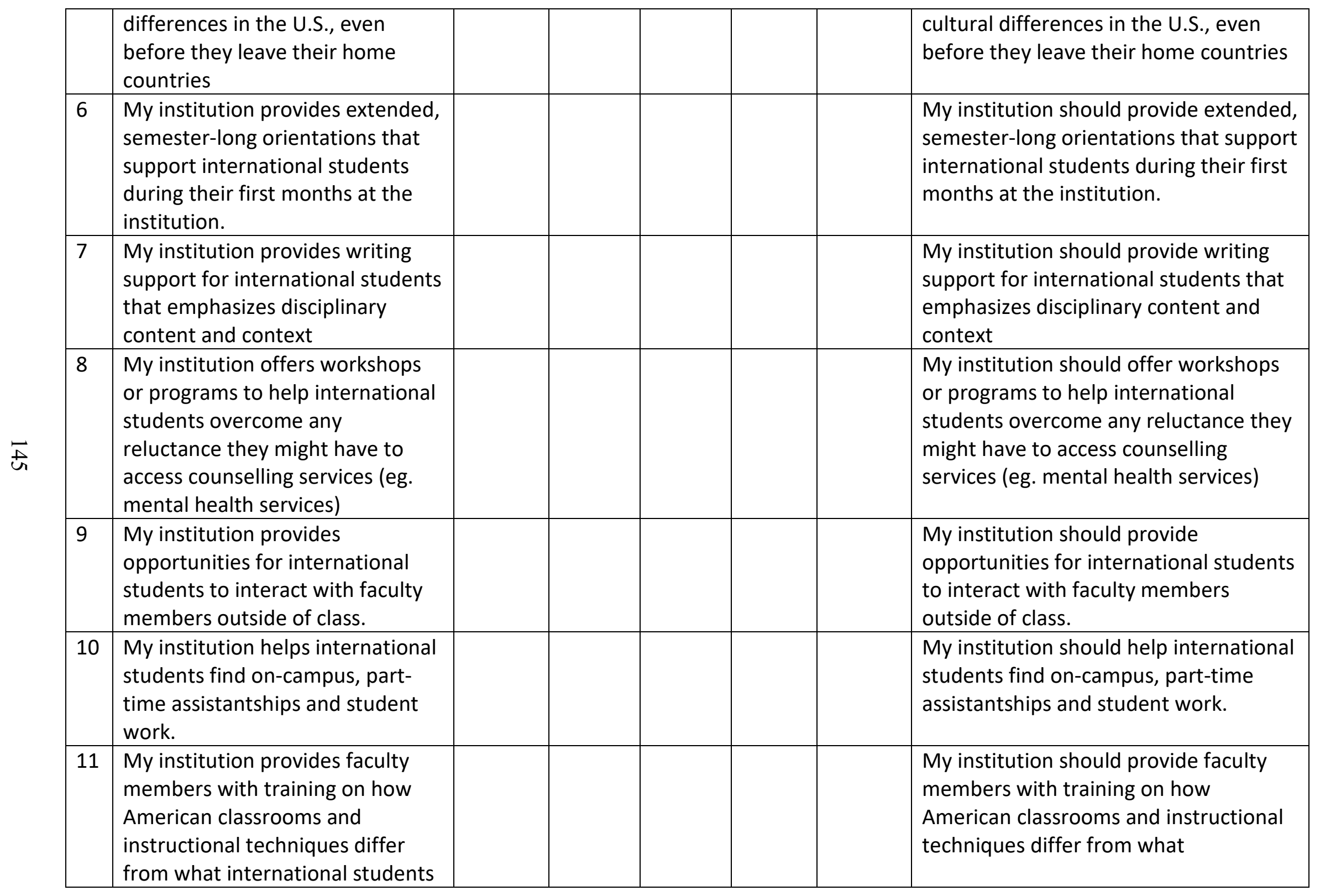




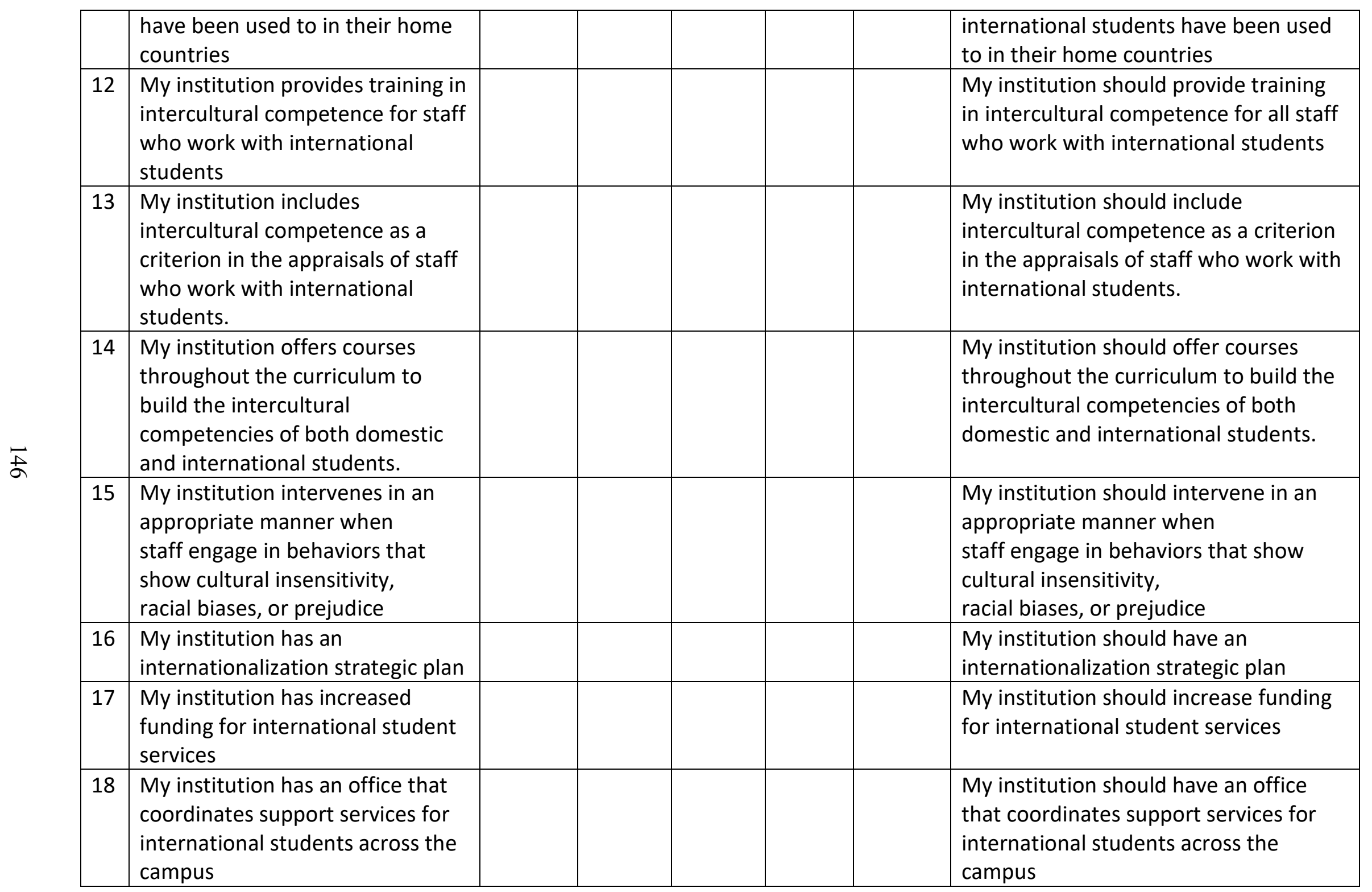




\begin{tabular}{|l|l|l|l|l|l|}
\hline 19 & $\begin{array}{l}\text { My institution adequately staffs } \\
\text { international student offices }\end{array}$ & & & & \\
\hline 20 & $\begin{array}{l}\text { My institution hires personnel in } \\
\text { international student offices who } \\
\text { have previous experience working } \\
\text { with international students }\end{array}$ & & & $\begin{array}{l}\text { My institution should adequately staff } \\
\text { international student offices }\end{array}$ \\
\hline 21 & $\begin{array}{l}\text { My institution develops religiously } \\
\text { affiliated centers for international } \\
\text { students, recognizing that their } \\
\text { cultural needs may be different from } \\
\text { those of domestic students }\end{array}$ & & & $\begin{array}{l}\text { My institution should hire personnel in } \\
\text { international student offices who have } \\
\text { previous experience working with } \\
\text { international students }\end{array}$ \\
\hline
\end{tabular}




\section{APPENDIX D: INFORMED CONSENT}

Dear Colleague,

I am requesting that you complete an online survey concerning the services provided in your institution for international students, and your perception on how these services could be improved. The survey will take 20-30 minutes to complete. Please read the following information carefully, and then indicate at the bottom of the page whether or not you would like to proceed.

Purpose of the study. This study employs an online survey of international student affairs personnel at higher education institutions to identify the services rendered for international students. The survey also asks the respondents about the gaps they perceive, if any, between the services that are used and the services that they feel should be implemented. The findings will be useful to higher education institutions as they consider strategies for the campus internationalization and in increasing enrollment of international students at their institutions.

Study procedures. Should you decide to participate, I will ask that you complete a survey that will take 20-30 minutes to complete. The survey provides a list of statements concerning various types of student services. You will be asked to rate (on 1-5 scales) your agreement with each statement in terms of (a) the extent to which the statement DOES reflect actual practice in your institution and (b) the extent to which the statement SHOULD reflect actual practice in your institution.

How you were selected for participation. You were selected as a potential participant in this study because of your membership in NAFSA and because, according to the website of your institution, you are engaged in serving international students at some capacity. 
Voluntary participation. Participation in this study is entirely voluntary. If you choose not to participate or would like to withdraw from the study at any time, there will be no penalty of any kind. You may also decline to answer any question you are uncomfortable with.

Risks. The main risk is breach of confidentiality. Each participant has the right to expect that his or her comments will remain confidential. Our intent is to develop an aggregate national picture of services for international students in higher education in the Midwest, and how it can be improved. Therefore, study results will be reported in aggregate only, and steps will be taken to minimize the risk of a breach of confidentiality. You are ineligible to participate if you are currently within the European Economic Area. Your data, even if deidentified, will not be used in other research projects.

Steps that will be taken to minimize risks. In addition to reporting aggregate results only, several steps will be taken to minimize the risk of a breach of confidentiality:

- Data will be collected via the Qualtrics online service. Only Sylvia Findlay and her dissertation adviser (Dr. Jim Palmer) will have access to survey responses typed in by study subjects at this site.

- The survey data will be collected anonymously using anonymous survey link which allows for the participant to take the survey without needing to provide credentials to log in.

https://www.qualtrics.com/support/survey-platform/distributions-module/webdistribution/anonymous-link/\#Introduction

- Collecting anonymous responses. Enabling this setting will remove the IP address and location data and disconnect the response from the person who provided it. In addition, IP addresses will be masked and not associated with responses by using the anonymous setting.

https://www.qualtrics.com/support/survey-platform/survey-module/survey-options/surveytermination/\#AnonymizingResponses 
- The survey does not ask for the respondent's name or for the name of his or her institution.

- Raw data will only be downloaded from the Qualtrics site and stored on (a) Jim Palmer's password protected PC at Illinois State University office, and (b) Sylvia Findlay's password-protected PC at her home. These data will not be stored or transmitted to any additional devices. Only Palmer and Findlay will have access to these raw data.

- The raw data in the Qualtrics account and in Ms. Findlay's computer will be erased after Ms. Findlay's dissertation is completed and filed with Illinois State University.

Benefits. The study will enhance our understanding of (a) the current services provided for international students at higher education institutions in the Midwest (b) the perception of how these services can be improved at institutions, and (c) gaps (if any) between the current practices and the services, in the opinion of student services personnel, that should be used. Study findings will also provide a picture of how institutions currently fare on providing international student services and help them institute internalization strategies that enhance campus services.

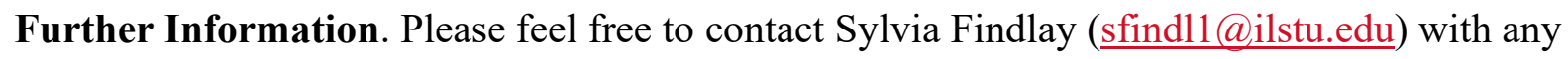
questions. You can also contact my dissertation advisor, Dr. Jim Palmer (jcpalmer@ilstu.edu). Should you have questions about your rights as a study participant and the steps undertaken to minimize the risks you will face as a participant, please feel free to contact the Research Ethics \& Compliance Office at Illinois State University (309) 438-5527. You may print a copy of this form for your records.

ELECTRONIC CONSENT: Please select your choice below. 
Clicking on the "agree" button below indicates that:

- you voluntarily agree to participate

- you are at least 18 years of age

If you do not wish to participate in the research study, please decline participation by clicking on the "disagree" button.

Agree

Disagree 


\section{APPENDIX E: REFERENCE GUIDE FOR THE STUDY PARTICIAPNTS \\ Reference Guide for the Study: Analysis of International Student Services}

Purpose of the study. This study employs an online survey of international student affairs personnel at higher education institutions to identify the services rendered for international students. The survey also asks the respondents about the gaps they perceive, if any, between the services that are used and the services that they feel should be implemented. The findings will be useful to higher education institutions as they consider strategies for the campus internationalization and in increasing enrollment of international students at their institutions.

Study procedures. Should you decide to participate, I will ask that you complete a survey that will take 5-10 minutes to complete. It provides a list of statements concerning various types of student services. You will be asked to rate (on 1-5 scales) your agreement with each statement in terms of (a) the extent to which the statement DOES reflect actual practice in your institution and (b) the extent to which the statement SHOULD reflect actual practice in your institution.

How you were selected for participation. You were selected as a potential participant in this study because of your membership in NAFSA and because, according to the website of your institution, you are engaged in serving international students at some capacity.

Voluntary participation. Participation in this study is entirely voluntary. If you choose not to participate or would like to withdraw from the study at any time, there will be no penalty of any kind. You may also decline to answer any question you are uncomfortable with. 
Risks. The main risk is breach of confidentiality. Each participant has the right to expect that his or her comments will remain confidential. Our intent is to develop an aggregate national picture of services for international students in higher education in the Midwest, and how it can be improved. Therefore, study results will be reported in aggregate only, and steps will be taken to minimize the risk of a breach of confidentiality. You are ineligible to participate if you are currently within the European Economic Area. Your data, even if deidentified, will not be used in other research projects.

Steps that will be taken to minimize risks. In addition to reporting aggregate results only, several steps will be taken to minimize the risk of a breach of confidentiality:

- Data will be collected via the Qualtrics online service. Only Sylvia Findlay and her dissertation adviser (Dr. Jim Palmer) will have access to survey responses typed in by study subjects at this site.

- The survey data will be collected anonymously using anonymous survey link which allows for the participant to take the survey without needing to provide credentials to log in.

\section{https://www.qualtrics.com/support/survey-platform/distributions-module/web-}

\section{distribution/anonymous-link/\#Introduction}

- Collecting anonymous responses. Enabling this setting will remove the IP address and location data and disconnect the response from the person who provided it. In addition, IP addresses will be masked and not associated with responses by using the anonymous setting.

https://www.qualtrics.com/support/survey-platform/survey-module/survey-options/surveytermination/\#AnonymizingResponses

- The survey does not ask for the respondent's name or for the name of his or her institution.

- Raw data will only be downloaded from the Qualtrics site and stored on (a) Jim Palmer's password protected PC at Illinois State University office, and (b) Sylvia Findlay's password-protected PC at her home. These data will not be stored or transmitted to any additional devices. Only Palmer and Findlay will have access to these raw data.

- The raw data in the Qualtrics account and in Ms. Findlay's computer will be erased after Ms. Findlay's dissertation is completed and filed with Illinois State University. 
Benefits. The study will enhance our understanding of (a) the current services provided for international students at higher education institutions in the Midwest (b) the perception of how these services can be improved at institutions, and (c) gaps (if any) between the current practices and the services, in the opinion of student services personnel, that should be used. Study findings will also provide a picture of how institutions currently fare on providing international student services and help them institute internalization strategies that enhance campus services.

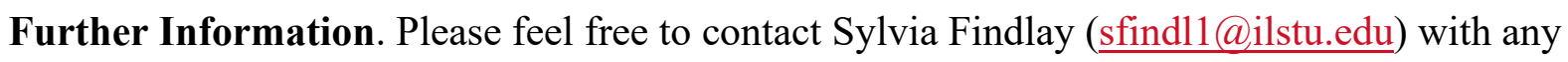
questions. You can also contact my dissertation advisor, Dr. Jim Palmer (jcpalmer@ilstu.edu). Should you have questions about your rights as a study participant and the steps undertaken to minimize the risks you will face as a participant, please feel free to contact the Research Ethics \& Compliance Office at Illinois State University (309) 438-5527. You may print a copy of this form for your records. 


\section{APPENDIX F: PAIRED STATEMENTS IN SES CATEGORY BY INSTITUTION TYPE}

\begin{tabular}{|c|c|c|c|c|c|c|c|c|c|c|}
\hline & & \multicolumn{3}{|c|}{ Four-year public college/university } & \multicolumn{3}{|c|}{$\begin{array}{l}\text { Four-year private non-profit college or } \\
\text { university }\end{array}$} & \multicolumn{3}{|c|}{$\begin{array}{l}\text { Four-year private for-profit } \\
\text { college or university }\end{array}$} \\
\hline & & $\begin{array}{l}\text { Don't } \\
\text { Know }\end{array}$ & $\begin{array}{c}\text { Total } \\
\text { Disagree }\end{array}$ & $\begin{array}{l}\text { Total } \\
\text { Agree }\end{array}$ & $\begin{array}{l}\text { Don't } \\
\text { Know }\end{array}$ & $\begin{array}{c}\text { Total } \\
\text { Disagree } \\
\end{array}$ & $\begin{array}{c}\text { Total } \\
\text { Agree } \\
\end{array}$ & $\begin{array}{l}\text { Don't } \\
\text { Know }\end{array}$ & $\begin{array}{c}\text { Total } \\
\text { Disagree }\end{array}$ & $\begin{array}{l}\text { Total } \\
\text { Agree } \\
\end{array}$ \\
\hline $\begin{array}{l}\text { My institution assesses } \\
\text { the extent to which } \\
\text { international students } \\
\text { are satisfied with } \\
\text { campus support } \\
\text { services. }\end{array}$ & \% (Count) & $2.2 \%(2)$ & $38.9 \%(35)$ & $58.9 \%(53)$ & $0 \%(0)$ & $35.8 \%(19)$ & $64.2 \%(34)$ & $0 \%(0)$ & $33.3 \%(1)$ & $\begin{array}{c}66.7 \% \\
(2)\end{array}$ \\
\hline $\begin{array}{l}\text { My institution should } \\
\text { assess the extent to } \\
\text { which international } \\
\text { students are satisfied } \\
\text { with campus support } \\
\text { services. }\end{array}$ & $\%$ (Count) & $0 \%(0)$ & $1.2 \%(1)$ & $98.8 \%(82)$ & $0 \%(0)$ & $0 \%(0)$ & $100 \%(50)$ & $0 \%(0)$ & $0 \%(0)$ & $\begin{array}{c}100 \% \\
(3)\end{array}$ \\
\hline $\begin{array}{l}\text { My institution provides } \\
\text { extended, semester-long } \\
\text { orientations for } \\
\text { international students } \\
\text { during their first } \\
\text { months at the } \\
\text { institution. }\end{array}$ & $\%$ (Count) & $2.3 \%(2)$ & $61.4 \%(54)$ & $36.4 \%(32)$ & $1.9 \%(1)$ & $67.9 \%(36)$ & $30.2 \%(16)$ & $0 \%(0)$ & $33.3 \%(1)$ & $\begin{array}{c}66.7 \% \\
(2)\end{array}$ \\
\hline $\begin{array}{l}\text { My institution should } \\
\text { provide extended, } \\
\text { semester-long } \\
\text { orientations for } \\
\text { international students } \\
\text { during their first } \\
\text { months at the } \\
\text { institution. }\end{array}$ & $\%$ (Count) & $3.5 \%(3)$ & $11.6 \%(10)$ & $84.9 \%(73)$ & $0 \%(0)$ & $20 \%(10)$ & $80 \%(40)$ & $0 \%(0)$ & $0 \%(0)$ & $\begin{array}{c}100 \% \\
(3)\end{array}$ \\
\hline
\end{tabular}




\begin{tabular}{|c|c|c|c|c|c|c|c|c|c|c|}
\hline $\begin{array}{l}\text { My institution provides } \\
\text { writing support for } \\
\text { international students } \\
\text { that goes beyond } \\
\text { grammar and } \\
\text { emphasize disciplinary } \\
\text { content and context. }\end{array}$ & \% (Count) & $4.4 \%(4)$ & $16.7 \%(15)$ & $78.9 \%$ (71) & $5,7 \%$ (3) & $15.1 \%(8)$ & $79.2 \%(42)$ & $0 \%(0)$ & $33.3 \%(1)$ & $\begin{array}{c}66.7 \% \\
(2)\end{array}$ \\
\hline $\begin{array}{l}\text { My institution should } \\
\text { provide writing support } \\
\text { for international } \\
\text { students that goes } \\
\text { beyond grammar and } \\
\text { emphasize disciplinary } \\
\text { content and context. }\end{array}$ & \% (Count) & $0 \%(0)$ & $1.2 \%(1)$ & $98.8 \%(83)$ & $0 \%(0)$ & $0 \%(0)$ & $100 \%(50)$ & $0 \%(0)$ & $0 \%(0)$ & $\begin{array}{c}100 \% \\
\text { (3) }\end{array}$ \\
\hline $\begin{array}{l}\text { My institution provides } \\
\text { opportunities for } \\
\text { international students to } \\
\text { interact with faculty } \\
\text { members outside of } \\
\text { class. }\end{array}$ & $\%$ (Count) & $10.2 \%(9)$ & $20.5 \%(18)$ & $69.3 \%(61)$ & $5.7 \%(3)$ & $17.0 \%(9)$ & $77.4 \%(41)$ & $0 \%(0)$ & $33.3 \%(1)$ & $\begin{array}{c}66.7 \% \\
\text { (2) }\end{array}$ \\
\hline $\begin{array}{l}\text { My institution should } \\
\text { provide opportunities } \\
\text { for international } \\
\text { students to interact with } \\
\text { faculty members } \\
\text { outside of class. }\end{array}$ & \% (Count) & $2.4 \%(2)$ & $6 \%(5)$ & $91.7 \%(77)$ & $2 \%(1)$ & $0 \%(0)$ & $98 \%(49)$ & $0 \%(0)$ & $33.3 \%(1)$ & $\begin{array}{c}66.7 \% \\
\text { (2) }\end{array}$ \\
\hline
\end{tabular}


APPENDIX G: PAIRED STATEMENTS IN ILS CATEGORY BY INSTITUTION TYPE

\begin{tabular}{|c|c|c|c|c|c|c|c|c|c|c|}
\hline & & \multicolumn{3}{|c|}{ Four-year public college/university } & \multicolumn{3}{|c|}{$\begin{array}{c}\text { Four-year private non-profit college or } \\
\text { university }\end{array}$} & \multicolumn{3}{|c|}{$\begin{array}{l}\text { Four-year private for-profit } \\
\text { college or university }\end{array}$} \\
\hline & & Don't Know & $\begin{array}{c}\text { Total } \\
\text { Disagree }\end{array}$ & $\begin{array}{r}\text { Total } \\
\text { Agree }\end{array}$ & $\begin{array}{l}\text { Don't } \\
\text { Know }\end{array}$ & $\begin{array}{c}\text { Total } \\
\text { Disagree }\end{array}$ & $\begin{array}{r}\text { Total } \\
\text { Agree }\end{array}$ & $\begin{array}{l}\text { Don't } \\
\text { Know }\end{array}$ & $\begin{array}{c}\text { Total } \\
\text { Disagree }\end{array}$ & $\begin{array}{r}\text { Total } \\
\text { Agree }\end{array}$ \\
\hline $\begin{array}{l}\text { My institution develops } \\
\text { religiously affiliated } \\
\text { centers for international } \\
\text { students, recognizing } \\
\text { that their cultural needs } \\
\text { may be different from } \\
\text { those of domestic } \\
\text { students }\end{array}$ & $\begin{array}{c}\% \\
\text { (Count) }\end{array}$ & $9.2 \%(8)$ & $49.4 \%(43)$ & $41.4 \%(36)$ & $3.9 \%(2)$ & $33.3 \%(17)$ & $62.7 \%(32)$ & $0 \%(0)$ & $33.3 \%(1)$ & $\begin{array}{c}66.7 \% \\
(2)\end{array}$ \\
\hline $\begin{array}{l}\text { My institution should } \\
\text { develop religiously } \\
\text { affiliated centers for } \\
\text { international students, } \\
\text { recognizing that their } \\
\text { cultural needs may be } \\
\text { different from those of } \\
\text { domestic students }\end{array}$ & $\begin{array}{c}\% \\
\text { (Count) }\end{array}$ & $5.8 \%(5)$ & $14 \%(12)$ & $80.2 \%(69)$ & $6 \%(3)$ & $14 \%(7)$ & $80 \%(40)$ & $0 \%(0)$ & $0 \%(0)$ & $\begin{array}{c}100 \% \\
(3)\end{array}$ \\
\hline $\begin{array}{l}\text { My institution has a } \\
\text { strategic plan for } \\
\text { international student } \\
\text { services or includes } \\
\text { international student } \\
\text { services in the strategic } \\
\text { plan of student affairs }\end{array}$ & $\%$ (Count) & $6.7 \%(6)$ & $33.7 \%(30)$ & $59.6 \%(53)$ & $3.8 \%(2)$ & $39.6 \%(21)$ & $56.6 \%(30)$ & $0 \%(0)$ & $\begin{array}{c}33.3 \% \\
(1)\end{array}$ & $\begin{array}{c}66.7 \% \\
(2)\end{array}$ \\
\hline $\begin{array}{l}\text { My institution should } \\
\text { have a strategic plan for } \\
\text { international student } \\
\text { services or includes } \\
\text { international student } \\
\text { services in the strategic } \\
\text { plan of student affairs }\end{array}$ & $\%$ (Count) & $0 \%(0)$ & $1.2 \%(1)$ & $98.8 \%(83)$ & $0 \%(0)$ & $6 \%(3)$ & $94 \%(47)$ & $0 \%(0)$ & $0 \%(0)$ & $\begin{array}{c}100 \% \\
(3)\end{array}$ \\
\hline
\end{tabular}


My institution's budget

includes monies that are specifically targeted

for international student services.

My institution's budget

should include monies

that are specifically

$$
\text { targeted for }
$$

international student

$$
\text { services. }
$$

\section{My institution} adequately staffs

international student

offices or international

student affairs offices.

My institution should adequately staff

international student offices or international student affairs offices.
$\%($ Count $) \quad 3.3 \%(3) \quad 25.6 \%(23) \quad 71.1 \%(64) \quad 0 \%(0) \quad 9.6 \%(5) \quad 90.4 \%(47) \quad 0 \%(0) \quad 0 \%(0)$

$100 \%$

$100 \%$

$66.7 \% \quad 33.3 \%$

$100 \%$ $\%($ Count $) \quad 0 \%(0) \quad 0 \%(0) \quad 100 \%(84) \quad 0 \%(0) \quad 0 \%(0) \quad 100 \%(50) \quad 0 \%(0) \quad 0 \%(0)$ 


\section{APPENDIX H: PAIRED STATEMENTS IN IGC CATEGORY BY INSTITUTION TYPE}

\begin{tabular}{|c|c|c|c|c|c|c|c|c|c|c|}
\hline & & \multicolumn{3}{|c|}{$\begin{array}{l}\text { Four-year public } \\
\text { college/university }\end{array}$} & \multicolumn{3}{|c|}{$\begin{array}{l}\text { Four-year private non-profit college or } \\
\text { university }\end{array}$} & \multicolumn{3}{|c|}{$\begin{array}{c}\text { Four-year private for-profit college } \\
\text { or university }\end{array}$} \\
\hline & & $\begin{array}{l}\text { Don't } \\
\text { Kno } \\
\text { w }\end{array}$ & $\begin{array}{l}\text { Total } \\
\text { Disagree }\end{array}$ & $\begin{array}{l}\text { Total } \\
\text { Agree }\end{array}$ & $\begin{array}{l}\text { Don't } \\
\text { Know }\end{array}$ & $\begin{array}{l}\text { Total } \\
\text { Disagree }\end{array}$ & $\begin{array}{l}\text { Total } \\
\text { Agree }\end{array}$ & $\begin{array}{l}\text { Don't } \\
\text { Know }\end{array}$ & $\begin{array}{l}\text { Total } \\
\text { Disagree }\end{array}$ & $\begin{array}{l}\text { Total } \\
\text { Agree }\end{array}$ \\
\hline $\begin{array}{c}\text { My institution provides } \\
\text { faculty members with training } \\
\text { on how American classrooms } \\
\text { and instructional techniques } \\
\text { differ from what international } \\
\text { students have been used to in } \\
\text { their home countries }\end{array}$ & $\begin{array}{c}\% \\
\text { (Count) }\end{array}$ & $\begin{array}{l}10.2 \\
\%(9)\end{array}$ & $40.9 \%(36)$ & $48.9 \%(43)$ & $5.7 \%(3)$ & $58.5 \%(31)$ & $35.8 \%(19)$ & $0 \%(0)$ & $66.7 \%(2)$ & $33.3 \%(1)$ \\
\hline $\begin{array}{l}\text { My institution should provide } \\
\text { faculty members with training } \\
\text { on how American classrooms } \\
\text { and instructional techniques } \\
\text { differ from what international } \\
\text { students have been used to in } \\
\text { their home countries }\end{array}$ & $\begin{array}{c}\% \\
\text { (Count) }\end{array}$ & $\begin{array}{l}2.3 \% \\
(2)\end{array}$ & $0 \%(0)$ & $97.7 \%(84)$ & $2 \%(1)$ & $0 \%(0)$ & $98 \%(49)$ & $0 \%(0)$ & $0 \%(0)$ & $100 \%(3)$ \\
\hline $\begin{array}{l}\text { My institution provides } \\
\text { training in intercultural } \\
\text { competence for faculty and } \\
\text { staff who work with } \\
\text { international students }\end{array}$ & $\begin{array}{c}\% \\
\text { (Count) }\end{array}$ & $\begin{array}{l}9.0 \% \\
(8)\end{array}$ & $37.1 \%(33)$ & $53.9 \%(48)$ & $5.7 \%(3)$ & $56.6 \%(30)$ & $37.7 \%(20)$ & $0 \%(0)$ & $100 \%(3)$ & $0 \%(0)$ \\
\hline $\begin{array}{l}\text { My institution should } \\
\text { provide training in } \\
\text { intercultural competence for } \\
\text { faculty and staff who work } \\
\text { with international students. }\end{array}$ & $\begin{array}{c}\% \\
\text { (Count) }\end{array}$ & $\begin{array}{l}1.2 \% \\
(1)\end{array}$ & $0 \%(0)$ & $98.8 \%(84)$ & $2 \%(1)$ & $2 \%(1)$ & $96 \%(48)$ & $0 \%(0)$ & $0 \%(0)$ & $100 \%(3)$ \\
\hline $\begin{array}{l}\text { My institution includes } \\
\text { intercultural competence as a } \\
\text { criterion in performance } \\
\text { appraisals of faculty and staff }\end{array}$ & $\begin{array}{c}\% \\
\text { (Count) }\end{array}$ & $\begin{array}{l}33.7 \\
\% \\
(29)\end{array}$ & $54.7 \%(47)$ & $11.6 \%(10)$ & $\begin{array}{c}25.0 \% \\
(13)\end{array}$ & $67.3 \%(35)$ & $7.7 \%(4)$ & $0 \%(0)$ & $33.3 \%(1)$ & $66.7 \%(2)$ \\
\hline
\end{tabular}


who work with international students.

My institution should include intercultural competence as a criterion in performance appraisals of faculty and staff

$\%$

(Count)

who work with international students.

My institution assures that courses throughout the curriculum build the intercultural competencies of both domestic and international students.

My institution should assure that courses throughout the curriculum build the

intercultural competencies of both domestic and international students.

My institution intervenes in an appropriate manner when faculty and staff engage in behaviors that show cultural insensitivity, racial biases, or prejudice

My institution should intervene in an appropriate manner when faculty and staff engage in behaviors that show cultural insensitivity, racial biases, or prejudice

$\%$

$\%$

(Count)

(Count)

$\%$
(Count) $\quad 21.3 \%(19)$

$36.0 \%$

(38)

(6)

$1.2 \%(1)$

$3.5 \%(3)$

$95.3 \%$

$0 \%(0)$

$2 \%(1)$

$98 \%(49)$

$0 \%(0)$

$0 \%(0)$

$100 \%(3)$

$7.9 \%(7)$

$22.5 \%$

$69.7 \%$

$17.0 \%$

(9)

$15.1 \%(8)$

$67.9 \%$

(36)

$33.3 \%$

(1)

$0 \%(0)$

$0 \%(0)$

$100 \%(86)$

$0 \%(0)$

$2 \%(1)$

98\% (49)

$0 \%(0)$

$0 \%(0)$

$100 \%(3)$ 